\title{
A colicin E7 nukleáz domén, mint egy lehetséges mesterséges metallonukleáz alapja
}

Doktori értekezés

Czene Anikó

TÉMAVEZETŐ: DR. GYURCSIK BÉLA

Szegedi Tudományegyetem, TTIK

Szervetlen és Analitikai Kémiai Tanszék

Kémia Doktori Iskola

Szeged, 2013 


\section{TARTALOMJEGYZÉK}

1. BEVEZETÉS

3. IRODALMI ÁTTEKINTÉS 5

3.1. METALLONUKLEÁZOK: A FÉMIONOK SZEREPE A KATALÍZISBEN 6

3.2. SPECIFIKUS ÉS NEM-SPECIFIKUS FEHÉRJE-DNS KÖLCSÖNHATÁSOK

3.3. A COLICINEK, MINT NEM-SPECIFIKUS HASÍTÁST VÉGZŐ ENZIMEK 9

3.3.1. A COLICINEK IMMUNITÁS-FEHÉRJÉINEK JELLEMZÉSE 10

3.3.2. A COLICINEK JÓL MEGŐRZÖTT KATALITIKUS KÖZPONTJA 11

3.3.3. A COLICIN E7 FEHÉRJE RÉSZLETES JELLEMZÉSE 13

4. MÉRÉSI MÓDSZEREK ÉS KÍSÉRLETI KÖRÜLMÉNYEK 18

4.1. A PCR (Polymerase Chain REACTION - Polimeráz lánCREAKCió) 18

4.2. GÉLELEKTROFORÉZIS 20

4.2.1. DNS KIMUTATÁSA AGARÓZ GÉLEN 20

4.2.2. SDS POLIAKRILAMID GÉLELEKTROFORÉZIS (SDS-PAGE) 21

4.3. REKOMBINÁNS DNS TECHNOLÓGIA

4.4. FEHÉRJEKIFEJEZÉS E.COLI SEJTEKBEN 25

4.5. NAGYHATÉKONYSÁGÚ FOLYADÉK-KROMATOGRÁFIÁS ELVÁLASZTÁS (HPLC) 27

4.6. TÖMEGSPEKTROMETRIA (ESI-MS)

4.6. CIRKULÁRIS DIKROIZMUS SPEKTROSZKÓPIA

4.7. RÖNTGEN KRISZTALLOGRÁFIA

4.8. MAGMÁGNESES REZONANCIA SPEKTROSZKÓPIA (NMR) 38

4.9. FLUORIMETRIA

5. KÍSÉRLETI EREDMÉNYEK ÉS ÉRTÉKELÉSÜK

5.1. A HNH MOTÍVUM ELŐÁLLÍTÁSA ÉS VIZSGÁLATA 41

5.1.1. A HNH MOTÍVUM GÉNJÉNEK ELŐÁLLÍTÁSA 41

5.1.2. A HNH MOTÍVUM GÉNJÉNEK BEÉPÍTÉSE CIRKULÁRIS DNS MOLEKULÁKBA 42

5.1.3. AZ UBIKVITIN (UB) FÚZIÓJA A HNH MOTÍVUMHOZ 43

5.1.4. UB-HNH FÚZIÓS FEHÉRJE KIFEJEZÉSE

5.1.5. UB-HNH FÚZIÓS FEHÉRJE TISZTÍTÁSA 46

5.1.6. UB-HNH ZN²+-KÖTÉSÉNEK VIZSGÁLATA 46

5.1.7. A HNH MOTÍVUM ELŐÁLLÍTÁSA UBIKVITIN-HNH (UB-HNH) FÚZIÓS FEHÉRJÉBŐL 50

5.1.8. A HNH MOTÍVUM ZN²+-KÖTÉSÉNEK VIZSGÁLATA

5.1.9. A HNH MOTÍVUM DNS KÖTÉSE ÉS NUKLEÁZ AKTIVITÁSA 54

5.1.10. AZ EREDMÉNYEK TÁRGYALÁSA

5.2. KÜLÖNBÖZŐ NCOLE7 MUTÁNSOK ELŐÁLLÍTÁSA ÉS VIZSGÁLATA

5.2.1. A $\triangle$ N25-NCOLE7 ÉS $\triangle$ N4-NCOLE7 FEHÉRJÉK ELŐÁLLÍTÁSA ÉS TISZTÍTÁSA 59

5.2.2. FEHÉRJE-ZN²+ KÖLCSÖNHATÁS VIZSGÁLATA TÖMEGSPEKTROMETRIÁVAL 62

5.2.3. FEHÉRJE - ZN ${ }^{2+}$ KÖLCSÖNHATÁS TANULMÁNYOZÁSA FLUORIMETRÁS MÉRÉSEKKEL 65

5.2.4. CIRKULÁRIS DIKROIZMUS A FEHÉRJE-ZN²+-ION KÖLCSÖNHATÁS VIZSGÁLATÁBAN 66

5.2.5. FEHÉRJE-DNS KÖLCSÖNHATÁS VIZSGÁLATA SRCD SPEKTROSZKÓPIÁVAL 67

5.2.6. GÉL MOBILITÁS VIZSGÁLATOK 68

5.2.7. EREDMÉNYEK ÉS TÁRGYALÁSUK

5.3. A $\Delta$ N4-NCOLE7 SZERKEZETMEGHATÁROZÁS VIZSGÁLATAI

5.3.1. A FEHÉRJÉK KRISTÁLYOSÍTÁSA

5.3.2. A COLICIN E7 NUKLEÁZ DOMÉN ÉS A $\triangle$ N4-NCOLE7 SZERKEZETÉNEK
ÖSSZEHASONLÍTÁSA 
5.3.3. ${ }^{13} \mathrm{C}$ ÉS ${ }^{15} \mathrm{~N}$ IZOTÓPOKKAL DÚSÍTOTT FEHÉRJE ELŐÁLLÍTÁSA NMR MÉRÉSEK CÉLJÁBÓL 82

5.3.4. EREDMÉNYEK ÉS TÁRGYALÁSUK

6. ÖSSZEFOGLALÁS 87

7. SUMMARY 90

8. RÖVIDÍTÉSEK JEGYZÉKE 93

9. HIVATKOZOTT KÖZLEMÉNYEK JEGYZÉKE 94

10. FÜGGELÉK 100

11. A DISSZERTÁCIÓ ALAPJÁT KÉPEZŐ KÖZLEMÉNYEK 104

12. KONFERENCIA MEGJELENÉSEK 105

13. KÖSZÖNETNYÍLVÁNÍTÁS 108 


\section{Bevezetés}

A nukleázok a nukleinsavak foszfodiészter kötéseinek hidrolitikus hasítását elősegítő enzimek. Ebben az élet szempontjából nagy jelentőséggel bíró folyamatban mind specifikus, mind nemspecifikus nukleinsav-szekvenciákat felismerő enzimek részt vesznek a célnak megfelelően. A rekombináns DNS technológia, felismerve a nukleázokban rejlő lehetőségeket, főleg a specifikus enzimeket alkalmazza, legelterjedtebben pl. a természetben is elöforduló bakteriális restrikciós endonukleázokat. Ezeknek az enzimek a segítségével számos, rájuk jellemző DNS szekvencia célzott hasítása vált lehetővé. Hátrányuk azonban, hogy a célszekvenciák viszonylag rövid DNS szakaszok, illetve nem választhatóak meg tetszőlegesen. Ilyen módon egy nagyobb méretü DNS, mint pl. a humán kromoszóma célzott kezelésére, nem alkalmasak. Tanulmányozásuk azonban jó kiindulópontot szolgáltatott olyan új mesterséges enzimek tervezéséhez és létrehozásához, melyek általunk meghatározott szekvenciák felismerésére és hasítására képesek.

Ez utóbbi enzimek jelentősége a DNS, illetve a gének módosításában, valamint a hibás gének javításában, azaz génterápiás alkalmazásban rejlik, ami miatt a mesterséges nukleázok fejlesztése a tudományos érdeklődés középpontjában áll. Kimutatták ugyanis, hogy a sejtek DNS javító mechanizmusainak müködése indukálható a DNS egy-, vagy kétszálú hasítása révén. Amennyiben ez utóbbi reakció egy hibás szekvenciával rendelkező DNS szakaszon (öröklött genetikai betegség, vagy rákos megbetegedést okozó génmódosulás), vagy annak közelében történik, és jelen van egy ép szekvenciájú DNS molekula is, akkor az ún. homológ rekombináció révén a sejt a hibás szekvenciát kijavíthatja.

Ilyen célra potenciálisan alkalmas, ún. kimer mesterséges nukleázt állítottak elő a FokI restrikciós endonukleáz önállóan funkciónáló nukleáz doménjéből, egy specifikus DNS szekvenciát felismerő ún. cink-ujj fehérjéhez füzve azt. Ezek a cink-ujj nukleázok az elmúlt 15 évben számos genetikai jellegü kísérlet alapját képezték, amelyek sikereinek következtében a humán terápiás alkalmazásokig is eljutottak. Sajnos ebben a fázisban a cink-ujj nukleázok nem váltották be a hozzájuk füzött reményeket, azaz ebben a formában nem használhatók fel genetikai megbetegedések kezelésében, ill. gyógyításában. Ennek oka a kezelések után egyes esetekben kialakult rákos megbetegedésre emlékeztető tünetek megjelenése volt, amit valószínüleg a mellékreakcióként lejátszódó nem-specifikus DNS hasítások eredményezhettek. 
Továbbra is igény mutatkozik tehát olyan mesterséges nukleázok tervezésére, amelyek biztonságos humán terápiás alkalmazást tehetnek lehetővé, nem kívánt mellékhatások nélkül. Ehhez olyan új moduláris nukleázok kifejlesztése vezethet el, melyek szabályozott módon müködnek. Tudjuk, hogy a természetes FokI enzimben a nukleáz domén allosztérikus gátlás alatt áll, mely funkció a DNS-kötő domént cinkujjakra cserélve megszünik - így magyarázható, hogy a nukleáz domén képes lehet nemspecifikus DNS hasításra is, ami a cink-ujj-részlet esetleges sérülése következtében egyre nagyobb gyakorisággal játszódhat le. Munkám kiindulópontjaként ezért egy olyan új nukleáz domént kerestem, amely az evolúció során jól megőrződött, és a fenti hátrányos tulajdonságoktól mentes. Ebböl kiindulva doktori értekezésemben egy olyan új nukleáz domén kiválasztásának és részletes tanulmányozásának folyamatát és eredményeit foglalom össze, amely biztonságosan müködő mesterséges nukleázok alapját képezheti. 


\section{Célkitüzés}

Egy biztonságosan müködő mesterséges nukleáz, mely a DNS lánc specifikus szekvenciájának felismerését követően az adott helyen elhasítja azt, nagy jövőbeli jelentőséggel bír, génterápiás távlatokat nyitva meg. Az ilyen enzimek kialakítására két fö stratégia ismert: meglévő, specifikus szekvenciát felismerő enzimek irányított módosítása, vagy kimer enzimek előállítása specifikus DNS szekvenciát felismerő fehérjék és önálló funkciós egységet kialakító nukleáz domének összefüzése révén. A manapság legelterjedtebben használatos mesterséges nukleázok egy specifikus szekvencia felismerésére alkalmas fehérjéből (cink-ujj fehérje) és a FokI restrikciós endonukleáz nukleáz doménjéből állnak. Mivel ezen enzimek a mellékreakcióként lejátszódó nem-specifikus hasítások miatt sejtmérgező hatással is rendelkeznek, elengedhetetlenül fontos egy olyan mesterséges nukleáz kifejlesztése, amely szabályozott módon képes müködni.

Ezért doktori munkám kiindulópontja egy új nukleáz domén keresése volt, mely kielégítve a fenti feltételt, egy mesterséges nukleáz alapját képezheti. A legújabb szakirodalom áttekintése után egy ilyen nukleáz kialakítására találtuk potenciálisan alkalmasnak a HNH motívumot, mint jól megőrződött katalitikus egységet, és az ilyen aktív központot a C-terminális végén tartalmazó colicin E7 metallonukleázt.

A fentiek megvalósítása érdekében doktori munkám első lépéseként a kiválasztott colicin E7 bakteriális toxin fehérje nukleáz doménjében (NColE7) található aktív központjának mélyebb megismerését terveztük. E fehérjemolekula C-terminális végén egy számos enzimben jól megörzött szerkezetű $\beta \beta \alpha$-fémionkötő részlet, ún. $\mathrm{HNH}$ motívum található. $\mathrm{E}$ motívumban $\left(\mathbf{H} \mathbf{H X}{ }_{14} \mathbf{N X}_{8} \mathbf{H} \mathbf{X}_{3} \mathbf{H}\right)$ három hisztidin oldallánchoz egy $\mathrm{Zn}^{2+}$-ion koordinálódik. A megőrzött szekvenciákhoz általában valamilyen fontos biológiai szerep rendelhető: a HNH motívum nukleáz aktivitásért lehet felelős. Elsőként tehát e 42 aminosavból álló HNH motívum előállítását, illetve tulajdonságainak vizsgálatát tüztük ki célul, hogy választ kapjunk arra, vajon e fehérjerészlet önmagában rendelkezik-e nukleáz aktivitással.

Mint azt az első pontban kitüzött vizsgálatok alapján kimutattuk, a katalitikus aktivitás létrejöttéhez szükség lehet az NColE7 DNS-kötő szekvenciájára is. Munkám második szakaszában így a minimális méretü működőképes egység keresésére fektettük 
a fö hangsúlyt, amelyhez az NColE7 N-terminális végen megrövidített fehérjemutánsainak előállításán keresztül kívántunk eljutni. E mutánsok tanulmányozásán keresztül az NColE7 egészét érintő kölcsönhatásokat, szerkezeti összefüggéseket próbáltuk megismerni, melyek hatással lehetnek az aktivitásra, illetve az aktív központban történő $\mathrm{Zn}^{2+}$-kötésre, valamint a DNS, mint szubsztrát megkötésére. Ehhez a $\Delta$ N69-NColE7, $\Delta$ N45-NColE7, $\Delta \mathbf{N 2 5 - N C o l E 7 ~ e ́ s ~} \Delta$ N4-NColE7 fehérjék előállítását, valamint az utóbbi két fehérje tisztítását és fémion, illetve DNS-kötő tulajdonságainak tanulmányozását tüztük ki célul gélelektroforézist, tömegspektrometriát, cirkuláris dikroizmus és fluoreszcencia spektroszkópiát felhasználva. E vizsgálatokból választ reméltünk arra, hogy milyen molekulán belüli kölcsönhatások játszanak fontos szerepet a nukleáz aktivitásban.

Munkám harmadik szakaszában $\Delta \mathrm{N} 25-\mathrm{NColE7}$ mutáns fehérje pontos térszerkezetének meghatározását terveztük. A röntgen-diffrakció alapján a fehérje kristályszerkezetére, míg az NMR spektrumokból a fehérje oldatbeli szerkezetére nézve nyerhetünk információt. A fehérje egykristály elöállítása meglehetősen időigényes és bonyolult feladat - a fehérje kifejezésének és tisztításának optimalizálása mellett számos különböző kristályosítási körülmény kipróbálása és ezek optimalizálása tartozik ide. A szerkezet meghatározására szintén alkalmas NMR mérésekhez ilyen célra megfelelö, ${ }^{13} \mathrm{C}$ és ${ }^{15} \mathrm{~N}$ izotópokkal dúsított fehérje előállítása és tisztítása szükséges. Az előző fejezetben elvégzett részletes vizsgálatok jobb megértését a teljes szerkezet meghatározása teszi lehetővé. Ezért a $\Delta \mathrm{N} 25-\mathrm{NColE} 7$ és $\Delta \mathrm{N} 4-\mathrm{NColE7-C}$ * fehérjék kristályosítását, valamint a $\Delta \mathrm{N} 4-\mathrm{NColE7}{ }^{*}$ fehérje előállítását tűztük ki célul ${ }^{13} \mathrm{C}$ és ${ }^{15} \mathrm{~N}$ izotópokkal dúsítva. A $\Delta \mathrm{N} 4-\mathrm{NColE7-C} *$ fehérje sikeresen meghatározott kristályszerkezetének elemzése a különböző körülmények között kristályosított NColE7 rendelkezésre álló szerkezeteivel történő összehasonlítás révén információval szolgálhat a hiányzó rész fontosságáról, illetve kölcsönhatásainak jelentőségéről a katalitikus aktivitás kialakításában. Ezen ismeretek reményeink szerint egy jövőbeli mesterséges metallonukláz tervezésének kiindulópontjaként szolgálhatnak. 


\section{Irodalmi áttekintés}

A napjainkban egyre inkább fejlődő in vitro és in vivo génmódosítás a jövőbeli génterápia előfutára. A génszabályozás, különböző génszakaszok kiütése, beültetése, illetve hibás DNS szakaszok javítása a sejteken belül egyre inkább valósággá válik [1]. E folyamatok kutatásának sikerét a sejtekben lejátszódó folyamatok részletes megismerése alapozhatja meg. A genomiális DNS sérülése indukálja a sejt önjavító mechanizmusait, különbözö rekombinációs folyamatokon keresztül [2-11]. Ezek egyike az úgynevezett nem homológ végek kapcsolódása, mely általában változást eredményez [12-13] az eredeti DNS szekvenciához képest. Egy ilyen folyamatot fel lehet használni célzott mutációk létrehozására, ugyankkor a homológ rekombináció képes a hibás gént kijavítani hibátlan DNS templát jelenlétében [14-18]. Bár ez utóbbi folyamat lejátszódásának természetes gyakorisága mindössze $10^{-6}$, azonban nagyságrendekkel növelhető egy nukleáz segítségével végrehajtott egy-, vagy kétszálú DNS hasítással a hibahely közvetlen közelében [19].

Specifikus szekvenciák felismerésére és hasítására alkalmas nukleázok a természetben is előfordulnak, azonban ezek többnyire rövid és így gyakran ismétlődő DNS szakasz felismerésére képesek. Egy akkora méretü DNS-ben, mint a humán genom, egy legalább 18 bázispárnyi szakasz tekinthető egyedi szekvenciának. Ilyen egyedi DNS-szekvencia kizárólagos felismerésére alkalmas mesterséges metalloenzimek tervezése ma már széles körben alkalmazott stratégiákon alapszik [2023]. A természetben előforduló nukleázok DNS-kötő doménjeiben ugyanúgy, mint a DNS-kötő fehérjékben egyes aminosavak mutációjával új szekvencia felismerése valósulhat meg. Ehhez a lehetö legtöbb információra van szükségünk a fehérjék és a DNS között kialakuló kölcsönhatásról. A röntgen-diffrakció és az NMR spektroszkópia a molekulák vagy azok komplexeinek teljes térbeli szerkezetét mutatja meg, továbbá egyre nagyobb hangsúlyt kap a számítógépes molekulamodellezés, mely szerves része a fehérjetervezésnek, újratervezésnek. Ez utóbbi módszer helytálló információkat szolgáltathat egy új, mesterséges fehérje várható szerkezetére nézve. Ennek tudatában a DNS-kötő fehérjék megváltoztatásával azok szerkezetére és kölcsönhatásaira kiterjedő információhoz juthatunk. Ezen eszköztárak felhasználásával megtervezett fehérjék arra alkalmas sejtekben kifejezhetőek, majd tulajdonságaik összevethetőek az elöre megjósoltakkal $[24,25]$. 


\subsection{Metallonukleázok: a fémionok szerepe a katalízisben}

Az RNS és DNS molekulák foszfodiészter kötéseinek félélettartama messze meghaladja az emberi élet maximált időtartamát. E kötések hasítása elengedhetetlenül szükséges az RNS és DNS szintéziséhez, a genom biológiai módosításához (beépülésinzerció, törlés-deléció, transzlokáció, rekombináció) és az idegen DNS lebontásához (baktériumok védekező mechanizmusa során) specifikus, vagy nem-specifikus módon. A legismertebb specifikus nukleázok az ún. restrikciós endonukleázok, melyek a DNS fragmentáción keresztül a rekombináns DNS technológia alapköveit jelentik [26]. Több, mint 3700 II. típusú restrikciós endonukleázt tartanak számon, mintegy 260 eltérő specifitással [27]. Egy másik nagy enzimcsalád az ún. önvezérlö, vagy homing endonukleázok, melyek akár 40 bp (bp = bázispár) hosszúságú bázisszekvencia felismerésére is képesek [28], szemben az előző csoport átlagos 6-8 bp-os szakaszaival. $\mathrm{Az}$ ilyen enzimeknek nagy jelentőségük van a molekuláris biológiai kutatásokban is. Ugyanakkor a nukleinsavak metabolizmusában szerepet játszó nem-specifikus DNS szekvenciák hasítását elősegítő nukleázok is felhasználhatók ismereteink bővítésére.

A mesterséges nukleázok tervezésének legfontosabb kiindulópontja a természetben előforduló nukleázok DNS-kötő és hasító mechanizmusának feltérképezése. Szükséges pontosan megismerni, hogyan kapcsolódik egymáshoz a fehérje és a DNS, mely aminosavaknak van kiemelt szerepe a DNS kötésében valamint hasításában, melyeknek a stabilis szerkezet fenntartásában. Ezen információk együttes ismeretében lehetünk képesek a megfelelő aminosavak megváltoztatásával elérni, hogy egy mesterséges nukleáz a kiválasztott DNS szakaszt ismerje fel, miközben mind a DNS kötés módja, mind pedig a hasítás mechanizmusa változatlan marad.

A legtöbb nukleáz fémiont tartalmaz, amely hozzájárul a szerkezet stabilitásához, illetve részt vesz a katalitikus folyamatban. A fémionnak különböző szinteken lehet szerepe a nukleáz aktivitásban, mint pl. a szubsztrátkötésben és felismerésben, annak elektrosztatikus aktiválásában, a nukleofil támadáshoz szükséges hidroxidion generálása során (3.1.1. ábra), a töltéskompenzációban, illetve stabilizálhatja a pentavalens intermediert és egy koordinálódott vízmolekula aktiválásával elősegítheti a távozó csoport protonálását [29]. 


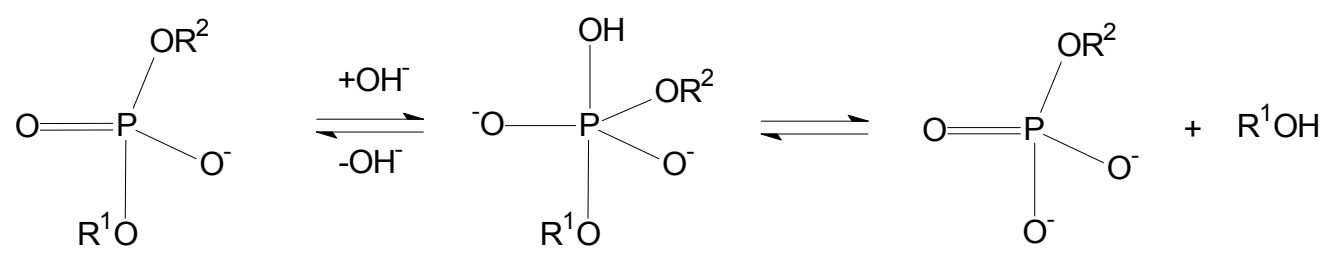

3.1.1. ábra: A foszfodiészter kötés fémion-katalizált hasításának általános mechanizmusa.

A fémionhoz koordinálódó aminosavak általában jól megőrzöttek. A savas oldalláncok az aktív központban $\mathrm{Mg}^{2+}$-iont képesek megkötni, mint hard Lewis sav jellegü (nagy töltéssürüségü) fémiont, míg pl. a $\mathrm{Zn}^{2+}$-ion a hisztidin $\mathrm{N}-$, illetve a cisztein S-donoratomjait részesíti előnyben.

A fémionok szerepére a DNS hidrolízisében legismertebb példa a $\mathrm{Mg}^{2+}$-ion a restrikciós endonukleázokban. A II-es típusú restrikciós endonukleázok a DNS hasítását

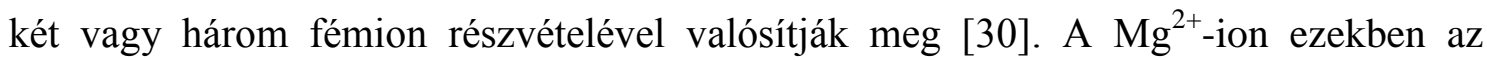
enzimekben, aktiválja a vízmolekulát a hasadó foszfodiészter kötés nukleofil támadásához, Lewis-savként stabilizálja a negatívan töltött foszforán intermedier átmeneti állapotot, majd a $\mathrm{Mg}^{2+}$-ion által megkötött vízmolekula egy protont ad át a távozó hidroxilcsoportnak. $\mathrm{A} \mathrm{Mg}^{2+}$-ion helyett ritkábban $\mathrm{Zn}^{2+}$-iont találunk ezeknek az enzimeknek az aktív központjában, amelynek hasonló szerepe lehet a katalízisben.

\subsection{Specifikus és nem-specifikus fehérje-DNS kölcsönhatások}

A DNS-kötő fehérjék általában több pozitív töltésü aminosav oldalláncot hordoznak. Így specifikus szekvenciát nem tartalmazó DNS jelenlétében ezek a fehérjék leginkább a DNS gerincének negatív töltésével alakítanak ki kölcsönhatást [31,32]. Az EcoRV és BamHI restrikciós endonukleázok specifikus és nem-specifikus DNS komplexének összehasonlítása alapján, a specifikus komplexben nagyobb fehérje-DNS érintkezési felület, kompaktabb szerkezet, figyelhető meg [33-35]. A specifikus fehérjék, mint például a fenti restrikciós endonukleáz enzimek a DNS gerincével és a bázisokkal is egyaránt közvetlen kölcsönhatásba lépnek. A specifikus fehérje-DNS kölcsönhatás jelentős konformáció-változást idézhet elö mind a DNS, mind pedig a fehérje szerkezetében, amely még szorosabb fehérje-DNS kölcsönhatást eredményez. A hasadó foszfodiészter kötés ezáltal általában közelebb kerül az enzim aktív központjához, ami lehetővé teszi annak hasítását. 
A FokI természetes nukleáz a Flavobacterium okeanokoites baktériumtörzsben fordul elő. A II-es típusú restrikciós endonukleázok különleges tagja, mivel a specifikus 5'-GGATG-3' DNS szekvencia felismerését követően a hasítást szekvencia közelében végzi [36]: ezen a szálon a 3' irányban 9 bp, míg a komplementer szálon az 5' irányban 13 bp távolságban. Ez az enzim két önálló funkcionális doménnel rendelkezik: egy Nterminális DNS felismerő és egy C-terminális DNS hasító doménnel (3.2.1. ábra), ahol a hasító domén egy linker szegmensen keresztül kapcsolódik a DNS szekvenciát felismerő doménhez [37].

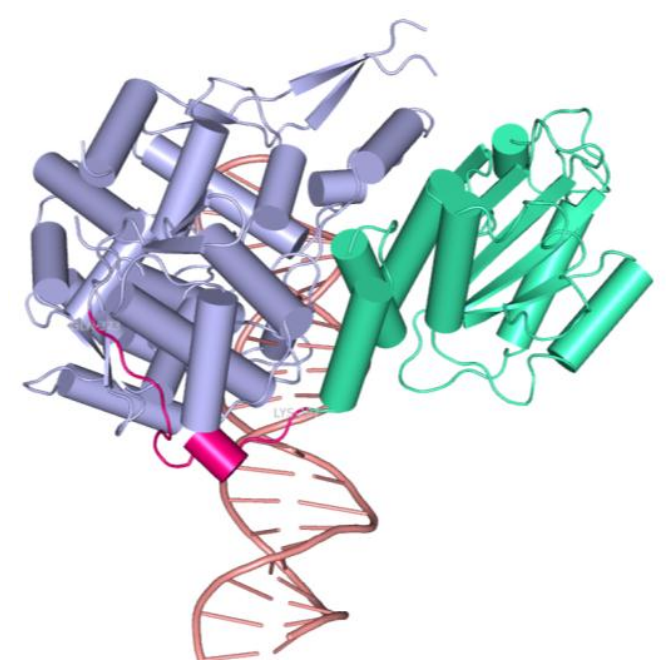

3.2.1. ábra: A DNS molekulát körülvevő FokI nukleáz szerkezeti ábrája. Zöld színnel az N-terminális DNS felismerő domént, lila színnel a C-terminális DNS hasító domént, ciklámen színnel pedig a mozgékony linker szegmenst jelöltük (PDB: 1FOK).

A hasításért felelős domén a BamHI enzimhez hasonló, azaz egy katalitikus központot tartalmaz, ami felveti a kérdést, hogy a monomer FokI hogyan képes a DNS mindkét szálát elhasítani. A FokI egy másik kristályszerkezetének meghatározásakor dimert detektáltak egy aszimmetrikus egységben (2FOK). Az első FokI momomer megköti a DNS-t az erre alkalmas doménjén keresztül $\mathrm{Mg}^{2+}$-ion jelenlétében úgy, hogy a hasító domén elkülönül a felismerő doméntől. A második FokI molekula kötődése után történik meg a dimerizáció a két molekula hasító doménjén keresztül. Ez teszi lehetővé a DNS kétszálú hasítását [38].

A jól elkülönült domének miatt a FokI enzimet alkalmasnak találták mesterséges nukleázok fejlesztésére [39-43]. Specifikus DNS szekvenciát felismerő cink-ujj fehérjékkel összefüzve ez az elképzelés meg is valósult és számos sikeres génmódosítási kísérletet hajtottak végre. Humán génterápiás alkalmazásuk során azonban toxikusnak bizonyultak: a kezelés a páciensek $\sim 15 \%$-ánál daganatos 
megbetegedésekhez vezetett [44]. Így a hozzá füzött génterápiás reményeket a cink-ujj nukleázok nem váltották be. Ennek oka a FokI müködésének ismeretében valószínüsíthető. A természetes FokI enzimben ugyanis a specifikus DNS szakasz felismerésekor bekövetkező szerkezeti változás teszi lehetővé, hogy a nukleáz domén kellő közelségbe kerüljön a DNS lánchoz, annak hasítása céljából [45,46]. Azonban ez a szabályozás a DNS-kötő rész eltávolításával vagy cseréjével megszünik. Így a cink-ujj nukleázok (részleges) lebomlása következtében a nukleáz domén véletlenszerü hasításokat eredményezhet a humán genomban. Elképzelésünk szerint ezen problémát orvosolni lehetne, egy új katalitikus domén alkalmazásával. Egy jól megőrzött szekvenciával és szerkezettel rendelkező katalitikus központ lehet az ún. HNH motívum [47], melyet elsőként önvezérlő endonukleázokban, majd összesen mintegy 3000 enzimben azonosítottak [48,49]. A HNH endonukleázok egyik különleges családját alkotják a colicin bakteriális toxinok. Ezért a továbbiakban ezen fehérjék jellemzésére térek ki részletesebben.

\subsection{A colicinek, mint nem-specifikus hasítást végző enzimek}

A colicinek baktériumsejtekben stressz hatására kifejeződő toxinok, melyek feladata az ellenségesnek ítélt baktériumsejtek elpusztítása. Közülük a nukleáz típusú colicinek a DNS nem-specifikus módon történő hasítása révén fejtik ki hatásukat (F.1. ábra). Az ebbe a családba tartozó 40-80 kDa molekulatömegü nukleázok szekvenciájukban és szerkezeti felépítésükben nagy hasonlóságot mutatnak. Három funkcionális doménre oszthatók (F.1. ábra): az N-terminális transzlokációs domén (T) a belső membránon történő átjutásért, a centrális receptorkötő domén $(\mathrm{R})$ a sejtfelszínen történő lokalizációért, míg a C-terminális citotoxikus (C) domén a nukleáz aktivitásért felelös [50].

Mára több mint 20 különböző colicinröl van részletes információnk, kristályszerkezeteken keresztül. A colicinek nevezéktana igyekszik csoportokba rendezni ezeket a fehérjéket. A colicinek E csoportjába tartozó fehérjék mindegyike $\mathrm{B}_{12}$ (BtuB) receptoron megkötődő fehérje, amely különböző módon képes a célsejtet elpusztítai. A colicin E1 ionofór, a colicin E3, E4, E6 RNáz aktivitással [51], míg a colicin E2, E7, E8, E9 DNáz aktivitással rendelkezik [52]. A C-terminális citotoxikus domén általában kisméretü, globuláris domén $\alpha$-hélixekkel vagy a nukleáz hatású 
colicineknél kevert $\alpha$-hélix, $\beta$-redő szerkezettel [51], melynek térbeli elrendeződését egy kétszeresen pozitív fémion stabilizálja. A négy colicin DNáz a C-terminális 134 aminosav tekintetében 70-80\%-os szekvencia-hasonlóságot mutat [53,54].

A colicin E7 (ColE7) és colicin E9 (ColE9) enzimeket tanulmányozták a legrészletesebben, ahol a fémion jelenlétét elengedhetetlennek találták azok müködéséhez. Habár a ColE7 fehérje fémion hiányában is képes megkötni a DNS-t, de annak hasítását már nem végzi el. A fémkötését illetően ugyanakkor ellentmondásokat találunk az irodalomban. A ColE7 és E9 enzimek müködését $\mathrm{Zn}^{2+}, \mathrm{Ni}^{2+}, \mathrm{Mn}^{2+}, \mathrm{Co}^{2+}$, illetve $\mathrm{Mg}^{2+}$, és $\mathrm{Ca}^{2+}$-ionok jelenlétében vizsgálták. A ColE7 endonukleáz aktivitása $\mathrm{Ni}^{2+}>\mathrm{Mn}^{2+} \sim \mathrm{Mg}^{2+}>\mathrm{Zn}^{2+}$ irányban csökken [55]. Eszerint mind az átmeneti fémionok, mind pedig a $\mathrm{Mg}^{2+}$-ion kofaktorként funkcionálhat a ColE7 endonukleáz müködése során. A ColE9 kristályszerkezetében $\mathrm{Ni}^{2+}$-ion található az aktív központban [56]. E fehérje nem mutatott nukleáz aktivitást $\mathrm{Zn}^{2+}$-ion jelenlétében, de $\mathrm{Ni}^{2+}$ és $\mathrm{Co}^{2+}$-ionok jelenlétében képes a DNS egyik szálának-, $\mathrm{Mg}^{2+}$-ion jelenlétében pedig mindkét szálnak elhasítására [57,58]. A fenti állításokat, miszerint ColE7 $\mathrm{Ni}^{2+}$ és $\mathrm{Zn}^{2+}$-ionok jelenlétében aktív ESI-MS mérésekkel is alátámasztották. Hogy mely fémionok milyen mértékben befolyásolják az endonukleáz aktivitást, informatív lehet arra nézve, hogy melyik fémion a ColE7 természetes kofaktora fiziológiás körülmények között. Az endonukleáz típusú colicinek a $\mathrm{Zn}^{2+}$-iont kötik a legerösebben [59]. A ColE9 $\mathrm{Zn}^{2+}$-kötésének becsült $\mathrm{K}_{\mathrm{d}}$ értéke kisebb mint $1 \mathrm{nM}$, míg a $\mathrm{Ni}^{2+}$ és $\mathrm{Co}^{2+}$-ionok esetében ez az érték $\mu \mathrm{M}$-os tartományba esik izotermális kalometriás titrálások alapján, a $\mathrm{Mg}^{2+}$-iont pedig sokkal gyengébben köti [57]. Valószínü, hogy a sejtekben újonnan szintetizálódott $\mathrm{Zn}^{2+}$-ionfüggő fehérjék, fémion-tartalmú dajkafehérjékből, illetve fémtároló fehérjékből nyerik a müködésükhöz szükséges $\mathrm{Zn}^{2+}$-iont. Az E. coli-ból tisztított $\operatorname{Im} 7-\mathrm{NColE7}$ komplex $\mathrm{Zn}^{2+}$-tartalmát atomemissziós és tömegspektrometriás mérések alapján valószínüsítették [60]. A $\mathrm{Zn}^{2+}$-ion kiszorítását csak $>25 \mathrm{mM} \mathrm{Mg}{ }^{2+}$-koncentráció esetében tapasztalták, ami arra utal, hogy a citoplazmában valóban $\mathrm{Zn}^{2+}$-kötés feltételezhető, mivel a $\mathrm{Mg}^{2+}$ koncentráció itt 1-2 mM az E. coli sejtekben [61].

\subsubsection{A colicinek immunitás-fehérjéinek jellemzése}

A saját nukleinsavaik védelme érdekében a baktériumok a nukleáz hatású colicinekkel párhuzamosan ( 10 kDa méretü) ún. immunitás-fehérjéket $(\mathrm{Im})$ termelnek, amelyek a nukleáz hatással rendelkező colicinek müködését a citotoxikus doménhez 
kötődve gátolják [62] (3.3.1.1. ábra). Szerkezetüket mind önállóan, mind pedig a colicinek katalitikus doménjével képzett komplexeinek kristályai alapján közölték az irodalomban. Ezen adatok részletes betekintést nyújtanak az enzimatikus colicinek inhibíciójának mechanizmusába. Az első szerkezeti információt a ColE7 és E9 immunitás-fehérjéikkel alkotott komplexei szolgáltatták [56,70]. A DNáz immunitásfehérjék 50\%-os szekvencia azonosságot mutatnak [54]. Szerkezetüket négy $\alpha$-hélix alkotja (3.3.1.1. ábra). Az inhibíció módja a colicinek E csoportjába tartozó fehérjéinél ugyanaz: az inhibítor a szubsztrátkötő hely egy részéhez kapcsolódva akadályozza meg a nukleinsavak megkötődését.

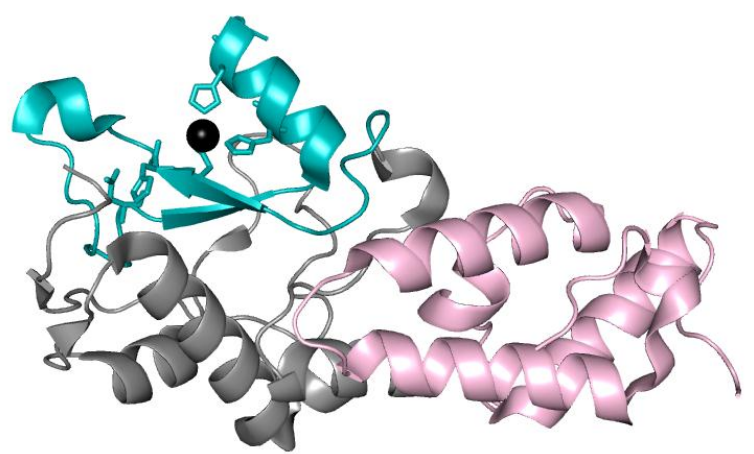

3.3.1.1. ábra: A ColE7 fehérjéhez (szürke) kötődő immunitás-fehérje (rózsaszín) a ColE7-Im7 komplex kristályszerkezetében. Kék színnel emeltük ki a HNH motívumot (PDB kód 1MZ8).

Az immunitás-fehérje savas oldalláncokon keresztül, míg a colicin E7 nukleáz doménje (NColE7) bázikus oldalláncokon keresztül alakít ki kölcsönhatást. Ezen fehérje-fehérje kölcsönhatás erős, specifikus komplexet eredményez, mely $K_{D} \sim 10^{-14}-10^{-17} \mathrm{M}$ látszólagos disszociációs állandó értekkel rendelkezik [63]. A leginkább savas karakterü fehérjerészlet az immunitás-fehérjében a D31-es aszparaginsav köré öszpontosul, amely az NColE7 R520 arginin aminosav körüli bázikus aminosavakkal lép kölcsönhatásba [54].

\subsubsection{A colicinek jól megőrzött katalitikus központja}

Az összes nukleáz hatású bakteriális toxin (colicin és piocin tipusú) C-terminális vége nagyon hasonló. Ez alkotja az enzimek aktív központját, a HNH motívumot, amely a DNS nemspecifikus hidrolízisét végzi. A HNH motívum névadó His, Asn, His aminosavjai $\mathrm{HHX}_{14} \mathrm{NX}_{8} \mathrm{HX}_{3} \mathrm{H}$ szekvencia mintázatban fordulnak elő (3.3.2.1. ábra), de ezek a névadó aminosavak a különböző fehérjecsaládokon belül is jól megőrződtek. 
HNH megốrzött szekvencia Colicinek-Colicin E7 Pyocinek-S1

I homing endonukleáz-HmuI II homing endonukleáz-Cpcl Restrikciós enzim-mtMSH Apoptotikus DNáz-CAD

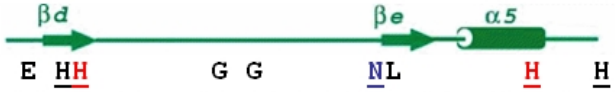

FEL $\overline{H H}$ EKPISQNG . GV . YDMDN ISVVTPKRH IDI $\bar{H} R-574$

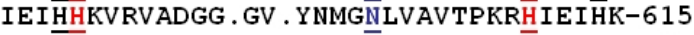

LVVDHKD . . . GNK . DN . NLST N LRWVTQKI N̄VENQM-101

IEIDHI IP . KSQG . GK . DVYDNLQALHRHCHDVKTA-566

LEV $\overline{H H}$ V IP . LSSG . GA. DTTD $\bar{N} C V A L C P N C \bar{H} R E L H Y-257$

DAVHH I KP6LCNR . KL . NRRSN LVPVCSSCH HDI $\bar{H} R-951$

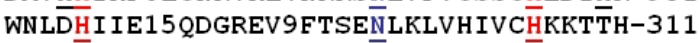

3.3.2.1. ábra: $A H N H$ motívumot tartalmazó aminosav szekvenciák összehasonlítása különböző fehérjecsaládokban [50].

A HNH motívum topologiája nagy hasonlóságot mutat a cink-ujj fehérjékhez. Mindkét szerkezet két, antiparalell lefutású $\beta$-redőből és egy $\alpha$-hélixből áll, $\mathrm{Zn}^{2+}$-ionnal a középpontjukban (3.3.2.2. ábra).
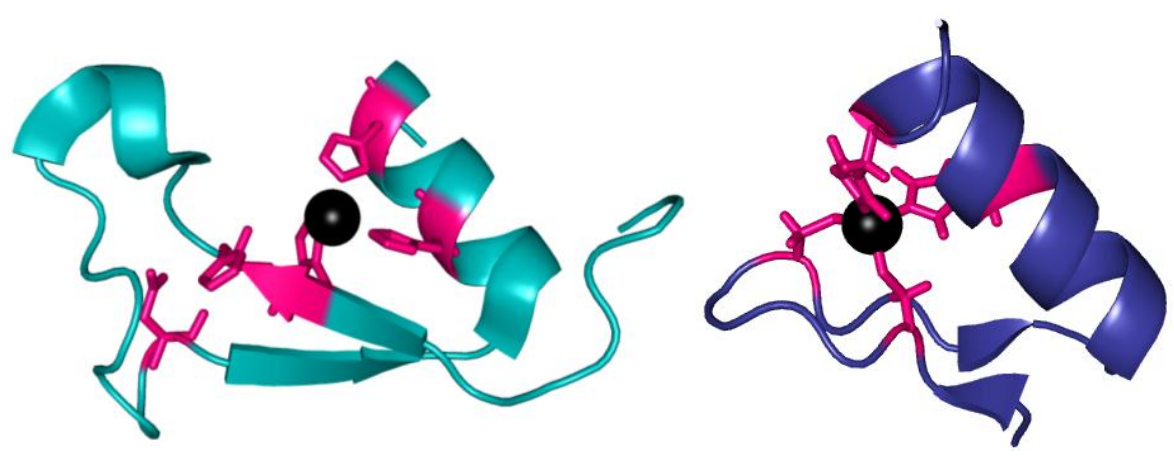

3.3.2.2. ábra: $\mathrm{HNH}$ motívum (bal oldal, $\mathrm{PDB}$ kód:1MZ8) és a cink-ujj fehérje (jobb oldal, PDB kód:1TF3) szerkezeti ábrája. Rózsaszínnel kiemelve a szekvenciában megőrzött aminosavak láthatóak. A HNH motívum esetében a $\mathrm{Zn}^{2+}$-ionhoz (fekete) három hisztidin oldallánc koordinálódik, míg a cink-ujj fehérjénél két hisztidin és két cisztein oldallánc koordinációja látható.

Mindkét motívum rendelkezik egy jól megőrzött C-terminális $\mathrm{HX}_{3} \mathrm{H}$ szekvenciával, melyben a hisztidinek oldalláncai a $\mathrm{Zn}^{2+}$-ion megkötésében vesznek részt. Míg azonban a cink-ujjakban a két deprotonálódott cisztein oldallánc a fémion pozitív töltését semlegesítve DNS-kötő fehérjét eredményez, addig a három His koordináció a HNH motívum katalitikus viselkedését segíti elő.

\section{A HNH motívum és a cink-ujj fehérjék szerkezeti különbségei:}

- a $\beta$-redők és az $\alpha$-hélix egymáshoz viszonyított térbeli orientációja eltérö: rövidebb az $\alpha$-hélix és sokkal hosszabb a hurok a két $\beta$-redő között a HNH motívumban;

- fehérje oldallánc helyett, vízmolekula koordinációja figyelhető meg a negyedik koordinációs helyen a HNH motívumban; 
- a $\mathrm{Zn}^{2+}$-ion koordinációs környezetében megjelenő cisztein-tiolát oldalláncok a cinkujjakban;

- a $\mathrm{Zn}^{2+}$-ion szerepe a cink-ujj fehérjékben a fehérje megfelelő konformációjának stabilizációja, ami a nukleinsavakkal kialakuló kölcsönhatáshoz szükséges;

- a $\mathrm{Zn}^{2+}$-ion szerepe a HNH motívumban katalitikus és szerkezetalakító [64-69].

\subsubsection{A colicin $E 7$ fehérje részletes jellemzése}

Az összes colicin fehérjét bakteriális plazmid kódolja. A colicin E7 operon tartalmazza cea, cei és cel géneket a 6,2 kbp natív plazmidban (pColE7-K317). A cea rész kódolja az 576 aminosavból álló ColE7 DNáz fehérjét, míg a cei rész a 87 aminosav hosszúságú Im7 fehérjét kódolja. A cei génről a transzkripció függetlenül is megtörténhet [70]. A cel gén egy lízis fehérjét (Lys-7) kódol a ColE7 szekréciójának elősegítéséhez. A Lys-7 egy 47 aminosav hosszúságú prekurzorként fejeződik ki, ami egy 28 aminosav hosszúságú fehérjeként aktív [71].

A colicin E7 DNáz doménje (3.3.3.1. ábra) DNS, illetve fémion jelenlétében több kristályszerkezetben megtalálható (3.3.3.1. táblázat), ami segít megérteni a kétszálú DNS hidrolízisének mechanizmusát [55,72,53]. A ColE7 fehérje a fémion jelenlétében elhasítja a minimum 8-10 bázispárból álló kétszálú DNS-t [73,74], egyvagy kétszálú hasítást végezve. Kisméretű szubsztráttal, mint dinukleotidokkal, ill. nukleotid-analógokkal nem mutatható ki aktivitás [53].

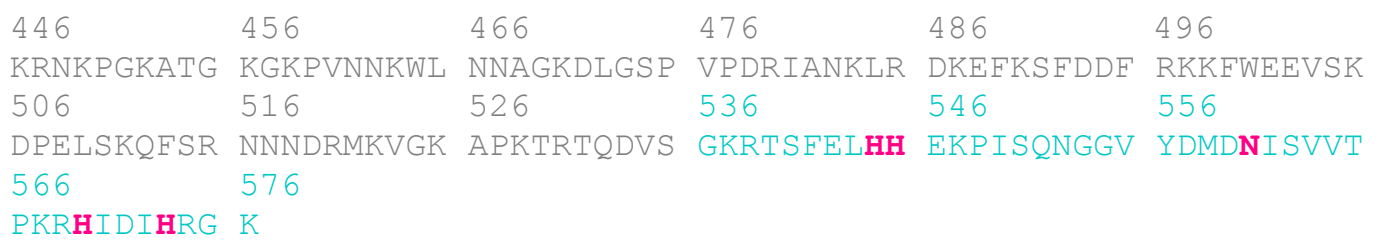

3.3.3.1. ábra: A ColE7 nukleáz doménjének (NColE7) szekvenciája, kék színnel a 42 aminosavból álló HNH motívumot, ciklámennel a konzervált His(H) és $\operatorname{Asn}(\mathrm{N})$ aminosavakat jelölve. (A számozás a teljes ColE7 fehérje alapján történt.)

A ColE7 fehérjének csak a citotoxikus doménje jut be a citoplazmába [81]: a nukleáz domén a K446 és R447 között hasad le a transzlokációs doménröl, egy specifikus proteáz segítségével. 
3.3.3.1. táblázat: A colicin E7 kristályszerkezeteinek adatai. Az fehérjék kifejezése minden esetben az Im7 immunitás-fehérje jelenlétében történt. A ColE7 nukleáz domén (NColE7) szekvenciája minden esetben MLDKS+446-576, kivéve a 7CEI kóddal rendelkező fehérjénél, ahol az N-terminális hexahisztidin toldalékkal (MRGSHHHHHHGSES) egészül ki a fehérje szekvencia. A jobboldali oszlop a kristályszerkezet alapján detektálható aminosav szekvenciát mutatja.

\begin{tabular}{|c|c|c|c|}
\hline PDB kód / ref. & Mutáció & Komplex & Szekvencia* \\
\hline $1 \mathrm{M08} /[75]$ & K446M & $\mathrm{N}$-ColE7-Zn-PO & 446 MRNK-HRGK 576 \\
\hline 1MZ8 / [76] & - & $\mathrm{N}-$ ColE7-Zn-PO $-\operatorname{Im} 7$ & 447 RNKP-IDIH 573 \\
\hline 1PT3 / [53] & - & N-ColE7-8bpDNA & 449 KPGK-HRGK 576 \\
\hline 1ZNS / [55] & K443M/H545E & N-ColE7-Zn-12bpDNA & 450 PGKA-DIHR 574 \\
\hline 1ZNV / [55] & K443M/H545E & $\mathrm{N}-\mathrm{ColE} 7-\mathrm{Ni}-\mathrm{PO}_{4}-\mathrm{Im} 7$ & 450 PGKA-HRGK 576 \\
\hline 7CEI / [60] & - & N-ColE7-Zn-Im7 & 447 RNKP-IDIH 573 \\
\hline 2IVH / [77] & H545Q & N-ColE7-Zn-18bpDNA & 449 KPGK-IDIH 573 \\
\hline 2JAZ / [78] & N560D & $\mathrm{N}$-ColE7-Zn-PO ${ }_{4}-\operatorname{Im} 7$ & 450 PGKA-HRGK 576 \\
\hline $2 \mathrm{JBO} /[78]$ & H573A & N-ColE7-Zn-Im7 & 449 KPGK-HIDI 572 \\
\hline 2JBG / [78] & N560A & $\mathrm{N}-\mathrm{ColE} 7-\mathrm{Zn}-\mathrm{SO}_{4}-\mathrm{Im} 7$ & 448 NKPG-HRGK 576 \\
\hline 3GJN / [79] & H545A & N-ColE7-Zn-Im & 450 PGKA-HRGK 576 \\
\hline $3 \mathrm{GKL} /$ [79] & H545A & N-ColE7-Zn-Im & 450 PGKA-HRGK 576 \\
\hline $3 F B D /[80]$ & D493Q & N-ColE7-18bpDNA & 445 SKRN-HRGK 576 \\
\hline
\end{tabular}

\section{Az arginin (R447) aminosav szerepe}

Az R447 aminosav fontos szerepet tölt be az enzimben, hiszen ennek eltávolítása vagy más aminosavakkal történő helyettesítése meggátolja a specifikus proteáz hasítást, és így a fehérje transzlokációját. Tehát az R447 aminosav cseréje a ColE7 citotoxikus hatás teljes megszünését eredményezi a ColE7 fehérjében [82]. Ugyanakkor a nukleáz aktivitás nem szünik meg teljesen, azaz az NColE7 in vitro hasítja a DNS-t: az R447A mutáció a ColE7 nukleáz doménjében $~ 10 \times$ kisebb nukleáz aktivitást eredményez. Ez a kisebb mértékü hasítás a feltételezések szerint nem az enzim katalitikus aktivitásának csökkenéséből, hanem a mutáns fehérje DNS-sel szemben mutatott affinitásnak csökkenéséből adódik.

A colicin E7 nukleáz doménjének (NColE7) kristályszerkezetében (1MZ8) az N-terminális végen lévő R447 hidrogénkötésekkel kapcsolódik a foszfátionhoz, ami a C-terminális HNH motívumhoz koordinálódó fémionhoz kötődő, hasadó foszfodiészter részletet modellezi az aktív központban [83] (3.3.3.2. ábra). Ez magyarázhatja, hogy az R447A mutánsnak miért van kisebb affinitása a DNS-hez, még akkor is, ha 
megtartotta endonukleáz aktivitását. Ezen feltételezések alapján az R447 aminosavnak a DNS kötésben lehet szerepe [82].
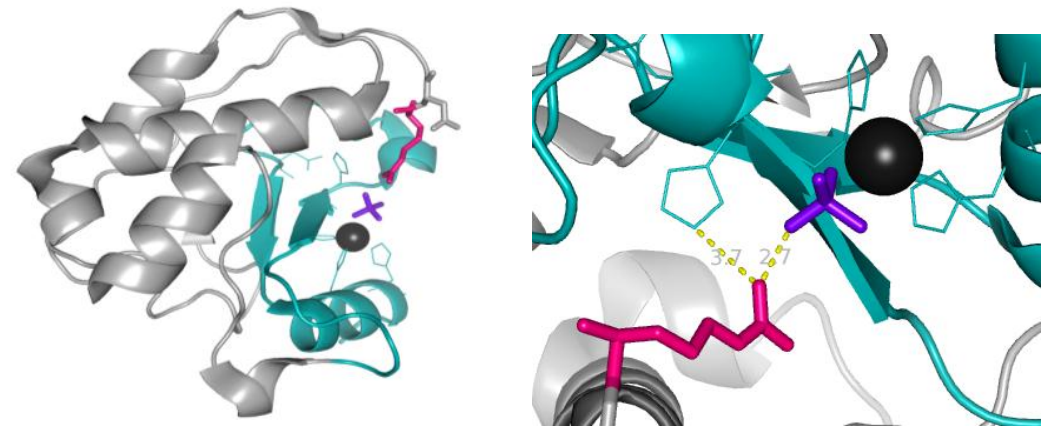

3.3.3.2. ábra: A colicin $E 7$ metallonukleáz aktív központjához közel hajló N-terminális R447 (ciklámen). A koordinálódó foszfátion lila színnel jelölve, a C-terminális HNH motívum (kék) három hisztidinjéhez koordinálódó $\mathrm{Zn}^{2+}$-ion fekete színnel jelölve látható az ábrán. Az arginintől mindössze 3,7 Å távolságra van a motívum negyedik jól megörzött hisztidinje (H545). Sárga vonalak a lehetséges hidrogénkötéseket szemléltetik (1MZ8). Az R447 vagy helyette lizin megőrződött az összes nukleáz hatású colicinben: az E csoport rRNáz (E3, E4, E6) és tRNáz (E5) colicinek mindegyikében megtalálható lizin, míg a nemspecifikus nukleáz colicinekben (E2, E7, E8, E9) arginin található a megőrződött helyzetben.

\section{A hisztidin oldalláncok szerepe a HNH motívumban}

A HNH motívum megőrződött aminosavjainak mutációja révén lehet következtetni azok szerepére. Esőként a hisztidin oldalláncok különböző mutációi (H545A, H545E, H545Q, H573A, H573E) során a $\mathrm{Zn}^{2+}$-ion kötését, illetve a nukleáz aktivitást vizsgálták. A H573A és H573E mutánsok esetében csökkent enzimaktivitást tapasztaltak a colicin E7-hez képest [78]. Bár ismert, hogy a H573 hisztidin a $\mathrm{Zn}^{2+}$-ion megkötésében játszik szerepet a H544, H569 aminosavak mellett (a fémion negyedik koordinációs helyét a DNS hasadó foszfodiészter részlete tölti be tetraéderes geometriát kialakítva), a H573A mutáns kristályszerkezetéből az is látható, hogy a $\mathrm{Zn}^{2+}$-ion az utóbbi két hisztidin oldallánchoz koordinálódva is beköthet az aktív központba.

A H545A, H545E mutációk az aktivitás teljes elvesztését jelentették [78], míg a H545Q mutáció esetében szignifikánsan lecsökkent, de nem szünt meg az aktivitás. Ezek alapján egyértelmü a H545 aminosav fontossága a DNS hidrolízisben. Ez a hisztidin valószínüleg egy közeli vízmolekulát deprotonálva generálja a nukleofil támadáshoz szükséges hidroxidiont. Az NColE7 H545E mutánsa és egy 12 bp DNS $\mathrm{Zn}^{2+}$-iont is tartalmazó komplexének (PDB kód: 1ZNS) és a természetes NColE7 8 bp DNS-sel alkotott $\mathrm{Zn}^{2+}$-ionmentes komplexének (PDB kód: 1PT3) összehasonlításán keresztül vizsgálták az apo-, és a holoenzim aktív központjának szerkezetét (3.3.3.3. ábra). 
(A)

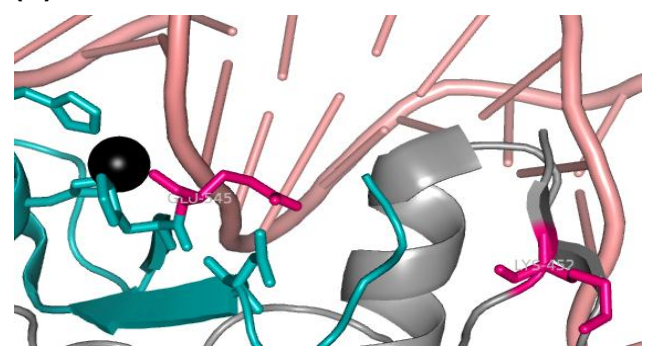

(B)

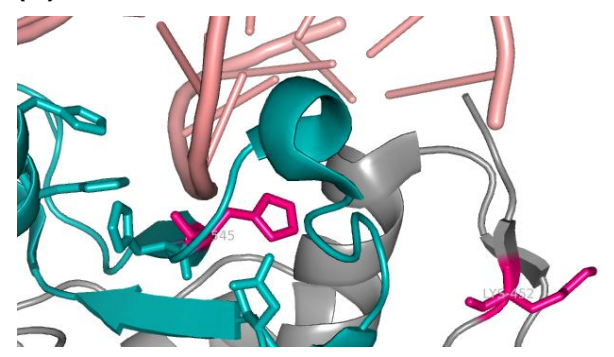

3.3.3.3. ábra: $\mathrm{A} \mathrm{Zn}^{2+}$-ion jelenlétében kristályosított $\mathrm{NColE} 7 \mathrm{H} 545 \mathrm{E}$ mutáns fehérje (A), illetve a $\mathrm{Zn}^{2+}{ }_{-}$ ion hiányos természetes NColE7 enzim aktív közponjának összehasonlítása (B).

A bázisként viselkedő H545 glutaminsavra történő cseréje megakadályozza az enzim aktivitását. Ezt támasztja alá az is, hogy a H545 közelében tartózkodó nukleofil vízmolekula sem látható a mutáns fehérje kristályszerkezetében (az ábra nem mutatja).

\section{Az aszparagin oldallánc (N560) szerepe a HNH motívumban}

A HNH motívumban megörzött aszparagin N560D, illetve N560A mutációja a $\beta$-redőket összekötő hurok rendezetlen szerkezetét eredményezte, mivel a hidrogénkötés hálózat az 560-as sorszámú aminosav körül megbomlott. Ennek eredményeként az általános bázisként müködő H545 imidazol gyürüje elbillen, elfordul és a hasadó foszfodiészter-csoport helyzete is eltolódik, jelentős csökkenést okozva a hidrolitikus aktivitásban [78]. Tehát a konzervált aszparagin szerkezet-stabilizáló szereppel bír a HNH motívumhoz tartozó hurok feszítésében. Ezzel az általános bázisként funkcionáló H545 aminosavat és a hasadó foszfodiészter-csoportot tartja a hidrolitikus reakció lejátszódásához megfelelő térbeli elrendezésben.

\section{Javasolt mechanizmus}

A colicin E7 nukleáz feltételezett működési mechanizmusa a 3.3.3.4. ábrán látható . A DNS hidrolízise az NColE7 aktív központjában lévő $\mathrm{Zn}^{2+}$-ion segítségével történik [84]: a központi fémion a H544, H569, H573 aminosavak oldalláncaihoz és a hasadó foszfodiészter csoporthoz tetraéderes geometriát kialakítva koordinálódik. A H545 bázisként müködik. Hidrogénkötést alakít ki a V555 karbonilcsoportjával, amely így polarizálja az imidazolgyürüt. Ez utóbbi egy protont von el egy közeli vízmolekulától, majd az így létrejövő $\mathrm{OH}^{-}$nukleofil támadást hajt végre a foszfodiészter kötés foszforatomján. A hasítás 3'-hidroxil és 5'-foszfát végeket eredményez [47,75,76,78]. Az N-terminális R447 oldallánc konformáció-változás révén 
kötődik és stabilizálja a hasadó foszfodiészter-csoportot. Egy hasonló mechanizmussal müküdő nukleáznál (Vvn nukleáz) látható egy, a fémionhoz $\left(\mathrm{Mg}^{2+}\right)$ koordinálódott vízmolekula is, amely a távozó csoport 3' oxigénjét protonálhatja. Az NColE7 szerkezetekben azonban nincs ilyen vízmolekula, ami ezt a feladatot elvégezné, így az még nem ismert, hogy minek tulajdonítható ez a szerep az NColE7-ben.

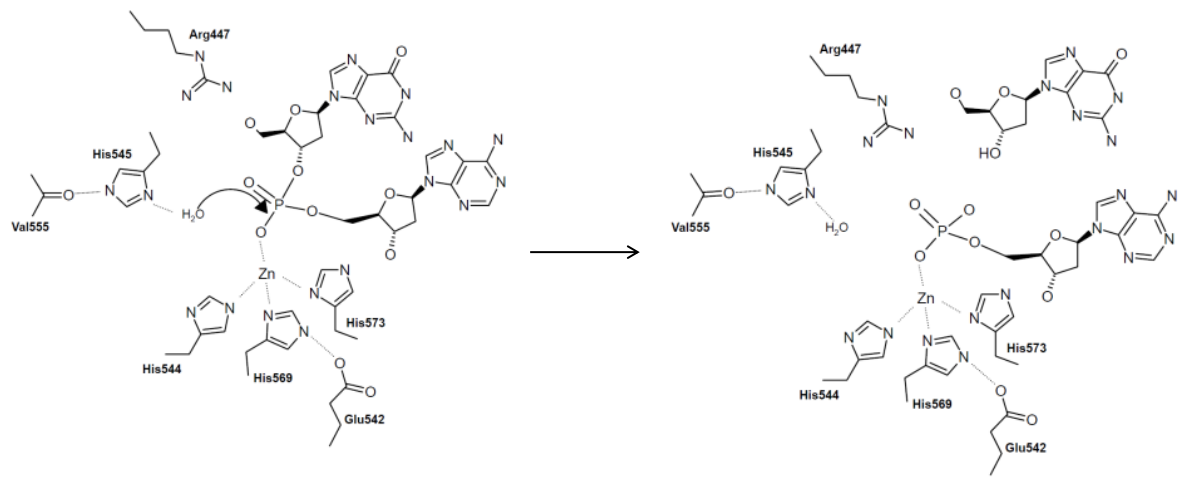

3.3.3.4. ábra: A colicin $E 7$ hidrolitikus hasitásának mechanizmusa sematikusan ábrázolva. A H545, mint általános bázis aktiválja a vízmolekulát a hasadó foszfodiészter-csoporton történő nukleofil támadáshoz. A kétszeresen pozitív töltésủ $\mathrm{Zn}^{2+}$-ion és az R447 között látható a hasadó foszfodiészter-csoport [85] 


\section{Mérési módszerek és kísérleti körülmények}

Mivel PhD munkám bioszervetlen kémiai jellegü, miközben a tanulmányozott fehérjék előállításához olyan módszereket alkalmaztam, melyek e tudományterület müvelöi számára nem szokványosak, szükségét éreztem, hogy az alábbiakban e módszereket valamivel részletesebben mutassam be, mint a jól ismert HPLC, vagy spektroszkópiai módszereket.

\subsection{A PCR (Polymerase Chain Reaction - Polimeráz láncreakció)}

A Kary Mullis által kidolgozott, Nobel-díjat érdemlő laboratóriumi módszer lehetővé teszi bármilyen eredetü DNS tetszőleges szakaszának gyors és olcsó, in vitro (tesztcsőben, laboratóriumi körülmények között történő) szaporítását az eredeti jelenlévő mennyiség sokszorosára. A technika a természetes replikációt is végző hőtürő DNS-polimeráz enzimek müködésén alapul. Az alkalmazás feltétele, hogy a sokszorosítandó DNS szakasz két végén 15-25 nukleotid sorrendje ismert legyen, a DNS fragmentumok enzimatikus szaporításához ugyanis olyan oligonukleotid primerek (indítószekvenciák) szükségesek, melyek a célszekvencia két fonalának 3'-végével komplementerek. Az egyszálú templát alapján a DNS polimeráz a primertől kiindulva 5 ' $\rightarrow 3$ ' irányban szintetizálja a komplementer szálat. A PCR komponensei tehát: DNStemplát - ez a DNS minta tartalmazza a sokszorosítandó DNS-szakaszt; két primer amelyek meghatározzák a sokszorosítandó szakasz kezdetét és végét; DNS-polimeráz amely másolja a sokszorosítandó szakaszt; dezoxi-nukleozid-trifoszfátok - melyekből a DNS-polimeráz felépíti az új DNS-t; $\mathrm{Mg}^{2+}$-tartalmú puffer - ami biztosítja a DNSpolimeráz számára megfelelő kémiai közeget. A polimeráz láncreakció a PCRkészülékben zajlik le. A készülék a reakcióelegyet ciklikusan felhevíti és lehüti a gondosan meghatározott, optimalizált hőmérsékletekre, amelyek a reakció egyes lépéseihez szükségesek. A PCR ciklusokból áll, egy ciklus pedig három lépésre bontható.

1 lépés: A reakcióelegyet $94-96^{\circ} \mathrm{C}-$ ra hevítik, hogy a kétszálú DNS szálai szétváljanak. Ebben a denaturálásnak nevezett lépésben a két DNS-szál közötti hidrogénkötések felbomlanak ( $\sim 30$ másodperc). Az első ciklus előtt a DNS-t gyakran hosszabb ideig (1-2 perc) denaturálják, hogy a kiindulási templát DNS kettős szálai is teljesen szeparálódjanak. A kromoszómális DNS templát esetében ez az idő még hosszabb lehet. 
2 lépés: Ezután a hőmérsékletet csökkentik, így a primerek hozzákapcsolódnak a DNSszálakhoz. Ezt a lépést annealing vagy kapcsolódási lépésnek nevezik. A hőmérséklet a primerektől függ, általában a primerek olvadási hömérséklete körüli optimalizált érték (45-60 $\left.{ }^{\circ} \mathrm{C}\right)$. Idő: $1-2$ perc.

3 lépés: Végül a DNS-polimeráz a specifikus módon hibridizálódott primertől kiindulva felépíti az új szálat. A lépés neve meghosszabbitás, ami a szintetizálandó nukleinsavszál meghosszabbítására utal. E folyamatban a szülő nukleinsav-szál szolgál templátként a leány-lánc szintéziséhez. A meghosszabbítás hőmérséklete a DNSpolimeráztól függően $68-72{ }^{\circ} \mathrm{C}$. A lépés időigénye egyrészt függ a DNS-polimeráztól, másrészt a sokszorozandó DNS-szakasz hosszától. Ökölszabályként a percenként 1000 bázispár beépítése történik meg. Ez egyben korlátozza a sokszorosítható DNS méretét is. Egy 10 kbp hosszúságú szakasz sokszorosítása, már meglehetősen komoly feladat. Mivel a PCR sikeressége nagyrészt a primerek tulajdonságaitól függ, érdemes ezekről külön is szót ejteni. A primerek hosszának és olvadási hömérsékletének $\left(T_{m}\right)$ kiválasztásakor több szempontot kell megfontolni. Az olvadási hőmérséklet nő a primer hosszával. A túl rövid primerek (alacsony olvadáspont) több helyre is kapcsolódhatnak egy hosszú DNS-templáton, ami nemspecifikus sokszorosításokat eredményez. Másfelől a primer hosszának az olvadási hőmérséklet szab határt. A túl magas olvadási hőmérséklet, pl. $80^{\circ} \mathrm{C}$ felett, azért jelent gondot, mert a DNS-polimeráz kevésbé aktív ilyen magas hőmérsékleten.

A fent említett megfontolások miatt a primerek tervezése aprólékos folyamat. Az alábbi szabályokat érdemes betartani: A GC-tartalom 40-60\% között legyen, a reakcióban használt két primer számított $\mathrm{T}_{\mathrm{m}}$ értékének különbsége $2{ }^{\circ} \mathrm{C}$ alatt legyen. A $\mathrm{T}_{\mathrm{m}}$ a következő képlet alapján becsülhető [86]:

$$
\mathrm{T}_{\mathrm{m}}=4(\mathrm{G}+\mathrm{C})+2(\mathrm{~A}+\mathrm{T})
$$

A kapcsolódási (annealing) hőmérséklet általában a becsült $\mathrm{T}_{\mathrm{m}} \pm 5{ }^{\circ} \mathrm{C}$. Mindazonáltal ezt kísérleti úton kell meghatározni az adott reakcióban.

A $>4 \mathrm{~N}$ belső, önmagával komplementer „hajtük” és a $>8 \mathrm{~N}$ dimerek kerülendők a primerek szekvenciáiban, ahol $\mathrm{N}$ a komplementer részben lévő nukleotidok számát jelöli. 
Egy kiemelt példaként részletesen bemutatjuk a $\mathrm{HNH}$ motívum génjének sokszorosításánál alkalmazott PCR körülményeket (4.1.1. táblázat).

4.1.1. táblázat: Egy PCR elegyhez szükséges komponensek, illetve azok mennyiségei, a HNH motívum génjének sokszorosítása példáján bemutatva.

\begin{tabular}{l|c|c|c|c|} 
Komponens & $\mathrm{C}_{\text {(kiindulási) }}$ & $\mathrm{C}_{\text {(végsó) }}$ & HNH & Vak Minta \\
\hline $10 \times$ PCR puffer & $10 \times$ & $1 \times$ & $5 \mu \mathrm{l}$ & $5 \mu \mathrm{l}$ \\
\hline $\mathrm{dNTP}$ & $2,0 \mathrm{mmol} / \mathrm{dm}^{3}$ & $0,2 \mathrm{mmol} / \mathrm{dm}^{3}$ & $5 \mu \mathrm{l}$ & $5 \mu \mathrm{l}$ \\
$\mathrm{MgCl}_{2}$ & $25 \mathrm{mmol} / \mathrm{dm}^{3}$ & $1,0 \mathrm{mmol} / \mathrm{dm}^{3}$ & $2 \mu \mathrm{l}$ & $2 \mu \mathrm{l}$ \\
\hline Primerek & $10 \mu \mathrm{mol} / \mathrm{dm}^{3}$ & $0,3 \mu \mathrm{mol} / \mathrm{dm}^{3}$ & $1,5-1,5 \mu \mathrm{l}$ & $1,5-1,5 \mu \mathrm{l}$ \\
\hline Templát DNS & - & $1 \mathrm{ng} / \mu \mathrm{l}$ & $1 \mu \mathrm{l}$ & - \\
\hline Taq polimeráz & - & $1 \mathrm{egység}$ & $0,3 \mu \mathrm{l}$ & $0,3 \mu \mathrm{l}$ \\
\hline Desztillált víz & - & - & $33,7 \mu \mathrm{l}$ & $34,7 \mu \mathrm{l}$ \\
\hline $\mathrm{V}_{\text {össz }}$ & - & - & $50 \mu \mathrm{l}$ & $50 \mu \mathrm{l}$
\end{tabular}

A DNS denaturálása: $94^{\circ} \mathrm{C}, 2$ perc, 30 cikluson keresztül ismételve: denaturálás $94{ }^{\circ} \mathrm{C}$, $30 \mathrm{mp}$, kapcsolódás $55^{\circ} \mathrm{C}, 30 \mathrm{mp}$, meghosszabítás $72{ }^{\circ} \mathrm{C}, 30 \mathrm{mp}$ majd $72{ }^{\circ} \mathrm{C}, 4$ perc. Végül $4{ }^{\circ} \mathrm{C}$-ra hütjük a reakcióelegyet további feldolgozásig. (A 10× megjelölés a táblázatban 10-szeres koncentrációt jelent.) A colicin E7 fehérjemutánsok génjének sokszorosításánál 1,5 percre növeltük a meghosszabítás időtartamát.

\subsection{Gélelektroforézis}

\subsubsection{DNS kimutatása agaróz gélen}

Az agaróz gélelektroforézis lehetőséget nyújt különböző méretü DNS fragmensek elválasztására és méretének közelítő meghatározására. A negatív töltéssel rendelkező DNS-molekula az egyenáramú elektromos erőtér hatására a pozitív pólus (anód) felé vándorol a gélben. Mozgását a mérete mellett befolyásolja az alkalmazott elektromos térerő, illetve a gél sürüsége. Minél kisebb a molekula, annál könnyebben, gyorsabban halad előre a gél üregeiben. Ismert méretü DNS fragmensek keverékének (marker) párhuzamos futtatásával a molekula mérete megbecsülhető. A gélen a DNS-t egy fluoreszcens festék, etídium-bromid alkalmazásával - amely a DNS kettős láncába beékelődve (interkaláció) UV fényben fluoreszkál - tesszük láthatóvá.

DNS mintáink vizsgálata általában 1,0-1,5\%-os agaróz gélen történt, kivéve a 400 bázispárnál kisebb méretü fragmensek elválasztásánál, amihez 1,5-2,0\%-os gélt 
használtunk. A DNS mintákból 5-5 $\mu$ l-t futattunk $150 \mathrm{~V}$ feszültség mellett fél-egy órán keresztül BIO RAD PowerPac ${ }^{\mathrm{TM}} / \mathrm{Sub}-\mathrm{Cell}^{\circledR}$ GT Cell készülékben. Az $5 \mu$ mintához 1 $\mu$ l 6× töménységü, festéket és glicerint tartalmazó oldatot kevertünk mielőtt a gél zsebeibe töltöttük.

\subsubsection{SDS poliakrilamid gélelektroforézis (SDS-PAGE)}

Főként fehérjék elválasztására szolgáló eljárás (4.2.2.1 ábra). Nátrium-dodecilszulfát (SDS) és redukálószerek jelenlétében a fehérjék denaturálódnak. A fehérjeoldathoz redukáló hatású $\beta$-merkaptoetanolt adva a polipeptid láncok közötti diszulfid-hidak felbomlanak, így a különböző fehérjemolekulák egységes alakot felvéve vándorolhatnak a gélben. Az SDS molekula erősen kötődik a polipeptid apoláros oldalláncaihoz. Ez a fehérjéknek méretükkel arányos negatív össztöltést biztosít, így azok molekulatömegük alapján jól elkülöníthetők.
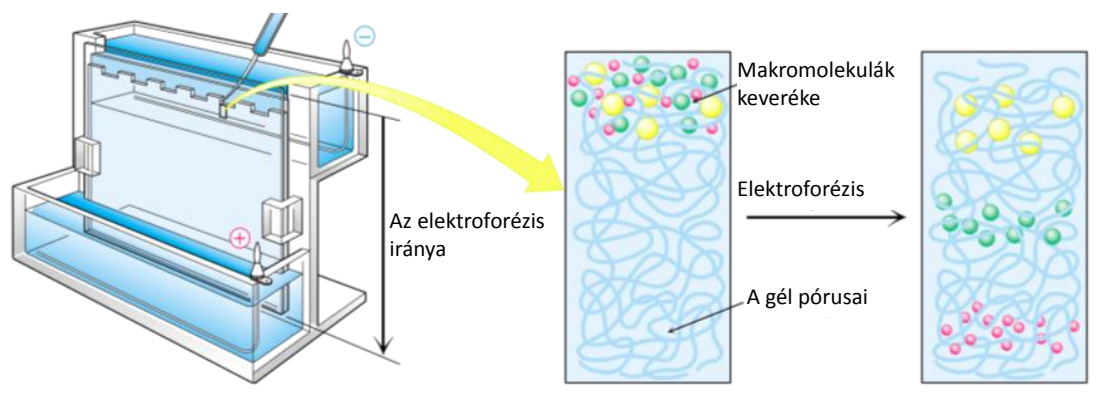

4.2.2.1 ábra: A poliakrilamid gélelektroforézis sematikus ábrája. A gélelektroforézis berendezés (bal oldal), illetve a negatív töltésü SDS-fehérje komplex anód felé történő vándorlása a gélben (jobb oldal). A gélben a legkisebb méretü fehérje (ciklámen) mozog a leggyorsabban [87].

A poliakrilamid gél pórusátmérője szabályozható. Az akrilamid molekula, megfelelő katalizátor és iniciátor jelenlétében gyökös polimerizációra képes, poliakrilamid képződik. A katalizátor általában ammónium-peroxo-diszulfát, ami vizes közegben spontán bomlik, így szabad gyököket eredményez. Ezek önmagukban az akrilamid-molekula kettőskötéseit nem hasítják el, ezt a feladatot az iniciátorként használt N,N,N',N'-tetrametil-etiléndiamin (TEMED) végzi el. A gél átlagos pórusmérete az akrilamid monomer koncentrációjának és a metilén-biszakrilamid arányának változtatásával szabályozható. Az elválasztás hatékonysága a fehérje molekulatömegétől függően glicint, illetve tricint (N-(2-hidroxi-1,1-bisz(hidroximetil)etil)glicin) tartalmazó SDS-pufferekkel javítható. 
A fehérjék kimutatásához előre elkészített gél állt a rendelkezésünkre (BIO RAD 12\% Tris-HCl). A marker szintén ennek a gyártónak a terméke (BIO RAD 161-0304 yellow), melyet háromszorosára hígítottunk. A zsebekbe 20-20 $\mu 1$ mintát töltöttünk 5-5 $\mu l$ merkaptoetanol tartalmú mintapufferrel összekeverve miután $3-5$ percig $80{ }^{\circ} \mathrm{C}$-on tartottuk őket. Futtató pufferben $100 \mathrm{~V}$ feszültség mellett 90 percig futtattuk a mintákat BIO RAD PowerPac ${ }^{\mathrm{TM} /}$ Mini-PROTEAN® Tetra cell készülékben, majd 1 órán át festettük és egy éjszakán át előhívó oldatban tároltuk a géleket. A folyamatok során végig BIO RAD vegyszerekkel dolgoztunk a gyártó leírásai alapján.

\subsection{Rekombináns DNS technológia}

A rekombináns DNS technológia segítségével cirkuláris kettősszálú bakteriális DNS hordozóba rövid kiválasztott DNS szakaszok inzertálása lehetséges. Hordozóként (vektor) leggyakrabban plazmidokat alkalmaznak. Ezek bakteriális eredetű kettős szálú 1-200 kbp méretű cirkuláris DNS molekulák (4.3.1 ábra), melyek kiegészítő genetikai egységként függetlenül replikálódnak a baktérium kromoszómájától. Laboratóriumban, mesterséges körülmények között az ún. transzformálás során a sejtfalat kétszeresen pozitív töltésü kationnal tesszük átmenetileg átjárhatóvá, így juttatva be a kívánt plazmidot a megfelelő baktériumtörzsbe. A sejtekben a plazmidok különböző számban találhatók meg egytől akár több százas tartományig.

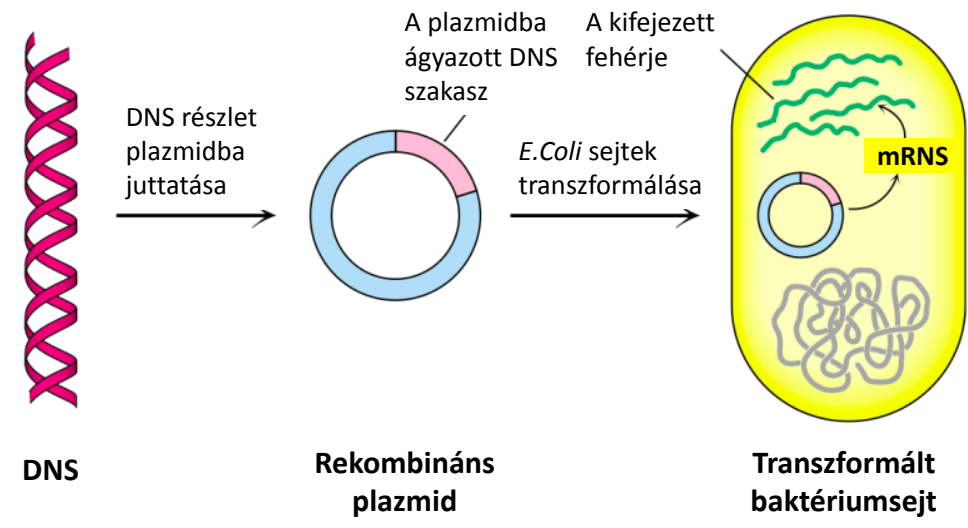

4.3.1 ábra: Baktériumsejt transzformálása rekombináns plazmiddal, fehérjekifejezés céljából [88]. 
A plazmidok megfelelő antibiotikum elleni rezisztenciát biztosítanak, restrikciós endonukleáz hasítási helyeket tartalmaznak, valamint egyesek közülük különböző fúziós fehérjék génjeit is, amik a későbbiekben a kifejezni kívánt célfehérje tisztítását könnyítik meg. Az egyedi restrikciós endonukleáz felismerési helyek teszik lehetővé az idegen DNS darab beillesztését a plazmidba. A restrikciós endonukleázok általában dimerként müködve palindrom DNS szekvenciákat ismernek fel. Ezeken a helyeken hasítják el a kettős szálú DNS-t a foszodiészter kötés hidrolízise révén. Amennyiben a hasítás következtében úgynevezett ragadós (túlnyúló) végek jönnek létre, ezek megkönnyítik egy olyan cél-DNS szakasz beillesztését, amelyet előzetesen ugyanezekkel az enzimekkel hasítottunk el. A ragadós végek komplementer bázispárjai között hidrogénkötések alakulnak ki, majd az 5'-foszfát és 3'-hidroxil végek közötti új kovalens foszfátészter kötés kialakítását az ún. ligáz enzim katalizálja. E folyamatot ligálásnak nevezzük. A ligáz ATP-t igényel kofaktorként a müködéséhez. Az inzert DNS beépülésének hatékonysága nem 100\%-os, mivel az elhasított végek egymással is újraligálódhatnak. Ez utóbbi mellékreakció megakadályozása céljából a hasított plazmidot foszfatáz enzimmel kezeljük, amely az 5'-végen lévő foszfátcsoport eltávolításával akadályozza meg a plazmid két végének összezáródását. Abban az esetben viszont, ha egy ilyen plazmid az inzert DNS-sel találkozik, képes lesz foszfátészter kötés kialakítására annak foszfátcsoportjával. Szélesebb körben alkalmazott stratégia a két különböző restrikciós endonukleázzal történő hasítás, amikor is a hasítás után a plazmid két végén található nem komplementer ragadós végek megakadályozzák az önligálódást, viszont elősegítik a hasonlóképpen kezelt inzert megfelelő irányú beépülését a plazmidba.

A fentieknek megfelelően a rekombináns plazmid DNS előállítása után azzal $E$. coli baktériumokat transzformálunk, és a megfelelő antibiotikum rezisztenciát kihasználva szaporítjuk öket. A plazmid DNS sokszorozására általunk alkalmazott baktériumtörzsek a DH5 $\alpha$, DH10B, Mach1 (Invitrogen ${ }^{\mathrm{TM}}$ ), XL10-Gold (Stratagene) voltak. Ezekben a sejtekben a fehérjekifejezés alacsony szintje nem zavarja a plazmid szaporítást. Az általunk használt plazmidok általában ampicillin antibiotikumrezisztenciát hordoztak, amely megakadályozza a sejtfal felépítését a peptidoglikán keresztkötések kialakításának gátlásával. A rezisztenciával rendelkező plazmidokról $\beta$ laktamáz enzim fejeződik ki, mely elhidrolizálja az ampicillin $\beta$-laktám-gyürüjét. Így csak azok a sejtek képesek szaporodni ampicillin-tartalmú táptalajon vagy tápoldatban, 
melyek tartalmazzák a rekombináns plazmid vektort és így hordozzák az antibiotikum elleni rezisztenciát is. Ezekből a sejtekből a további kísérletekhez megfelelő mennyiségű plazmid tisztítható.

Vektor sokszorozás, tisztítás: Ahhoz, hogy a rendelkezésünkre álló kiindulási vektorokba a PCR-ben általunk előállított gént inzertálhassuk mind a vektornak mind a génnek megfelelő mennyiségben kellett rendelkezésünkre állnia. Első lépésként tehát a vektort baktériumsejtekben sokszoroztuk, tisztítottuk. A kompetens (transzformálásra előkészített) sejtek $100 \mu \mathrm{l}$-ét $1,5 \mathrm{ng}$ vektorral elegyítettük egy 3 ml-es tesztcsőben, majd 30 percig jégen tartottuk, 45 másodpercig $42{ }^{\circ} \mathrm{C}$-on, majd 2 percig újra jégen. 450 $\mu$ LB tápoldatot adtuk a baktériumtenyészethez, majd antibiotikum-tartalmú LB táptalajra kentük ki a sejteket. $37^{\circ} \mathrm{C}$-on egy éjszakán át növesztettük öket, majd egyegy baktériumtelepet (kolóniát) 5-5 ml antibiotikum-tartalmú LB (LBamp) tápoldatban szaporítottunk tovább egy éjszakán át, $37^{\circ} \mathrm{C}$-on, $250 \mathrm{rpm}$ rázatás mellett. Ezután DNStisztítására alkalmas kit segítségével (GenElute Plasmid Miniprep Kit - Sigma) a baktériumokból kinyertük a cirkuláris DNS-t. A $2 \times 5$ ml-es tápoldatból a tisztítás végére $2 \times 50 \mu \mathrm{l}$ vízben oldott plazmid állt rendelkezésünkre. A kövekező lépésben a plazmidot a ligáláshoz kiválasztott restrikciós enzimekkel hasítottuk. $84 \mu$ lisztított plazmidhoz 10 $\mu \mathrm{l} 10 \times$ puffert adtunk, majd 3-3 $\mu \mathrm{l}$-t a kiválasztott restrikciós enzimekből (New England Biolabs). Ezt az elegyet $37{ }^{\circ} \mathrm{C}$-on egész éjszakán át emésztettük, majd $1 \mu \mathrm{l}$ foszfatáz (CIAP - Calf Intestinal Alkaline Phosphatase) enzimet adtunk az elegyhez, amivel újabb 1 órán keresztül $37^{\circ} \mathrm{C}$-on inkubáltuk. A reakcióelegyet agaróz gélre vittük fel $100 \mu$ mintához $20 \mu$ festéket adva, majd $100 \mathrm{~V}$-on 30 percig futattuk. A gélböl kit (GenElute GelExtraction Kit - Sigma) segítségével tisztítottuk az elhasított plazmidot. Ugyanezt a folyamatot - az alkalikus foszfatázzal történő emésztés kivételével megismételtük a PCR eleggyel, amely az általunk beilleszteni kívánt gént tartalmazta. $21 \mu \mathrm{l}$ PCR terméket 0,75-0,75 $\mu$ l enzimmel emésztettünk 2,5 $\mu \mathrm{l} 10 \times$ NEB puffer jelenlétében. A restrikciós enzimekkel történő emésztés szintén $37{ }^{\circ} \mathrm{C}$-on egy éjszakán át történt, majd a hasított fragmenst agaróz gélből tisztítottuk. Ezután a ligáz enzim segítségével beillesztettük a plazmidba az így előállított gén szakaszt. A ligálási elegy 4,2 $\mu \mathrm{l}$ inzert DNS-t, 4,2 $\mu \mathrm{l}$ vektort, $1 \mu \mathrm{l} 10 \times$ ligáló puffert és $0,5 \mu \mathrm{T}$ T4 ligáz enzimet (Fermentas) tartalmazott. Ezt egy éjszakán át $16{ }^{\circ} \mathrm{C}$-on tároltuk. Ebből az elegyből a fent említett módon transzformáltunk kompetens $E$. Coli sejteket, hogy elszaporítsuk a 
már inzertet is tartalmazó rekombináns cirkuláris DNS-t. A szaporítás és tisztítás után, szekvenálási reakcióban ellenőriztük, hogy az inzert valóban beépült-e a kívánt helyre.

Kompetens sejtek készítése: A $-80{ }^{\circ} \mathrm{C}$-on tárolt baktériumsejtek szuszpenzióját antibiotikum-mentes LB táptalajra kentük ki, majd $37{ }^{\circ} \mathrm{C}$-on egy éjszakán át inkubáltuk és felhasználásig $4^{\circ} \mathrm{C}$-on tároltuk. Egy telepről baktériumsejteket juttattunk $50 \mathrm{ml} \mathrm{LB}$ tápoldatba, majd intenzív keverés mellett (300 fordulat/perc) $37{ }^{\circ} \mathrm{C}$-on, 3 órán keresztül inkubáltuk. Steril fülke alatt fertőzésmentes körülmények között, steril 50 ml-es tesztcsőbe öntöttük a sejtszuszpenziót, 10 percig jégen tároltuk, majd centrifugálással ülepítettük a sejteket (4000 rpm (fordulat/perc), 10 perc, $4^{\circ} \mathrm{C}$, Sorvall GS3 rotor). A felülúszó eltávolítása után a sejteket $25 \mathrm{ml}$ jéghideg $0,1 \mathrm{M} \mathrm{CaCl} \mathrm{Cl}_{2}$ oldatban szuszpendáltuk, majd jégen tartottuk 1 órán keresztül. Újra centrifugáltuk (4000 rpm, 10 perc, $\left.4{ }^{\circ} \mathrm{C}\right)$. A felülúszó eltávolítása után a kompetens sejtek azonnal fel nem használt részét $-80^{\circ} \mathrm{C}$-on tároltuk.

Sejtek transzformálása: A kompetens sejtek $100 \mu$ l -ét steril reakciócsőbe mértük, majd 1-10 $\mu 1$ plazmidot vagy ligálási elegyet adtunk hozzá attól függően, hogy éppen milyen célból szerettük volna ezeket szaporítani. Ezután 20 percig jégen inkubáltuk a sejteket, majd 90 másodpercre $42{ }^{\circ} \mathrm{C}$-os vízfürdőbe helyeztük a csövet, majd újra jégre tettük 2 percig. $400 \mu \mathrm{LB}$ tápoldat hozzáadása után a sejteket antibiotikum-tartalmú LB táptalajra kentük ki, majd egy éjszakán át $37{ }^{\circ} \mathrm{C}$-on inkubáltuk. Másnap reggel a lemezről néhány baktériumtelepet kiválasztottunk, amelyeket $3 \mathrm{ml}$ antibiotikumtartalmú $(100 \mu \mathrm{l} / \mathrm{ml}) \mathrm{LB}$ tápoldatban tovább növesztettünk $37{ }^{\circ} \mathrm{C}$-on $225-250 \mathrm{rpm}$ rázatással egy éjszakán át. A baktériumtenyészet 0,5 ml-ét, $116 \mu \mathrm{l}$ 80\%-os steril glicerinnel elegyítettük és $-80{ }^{\circ} \mathrm{C}-\mathrm{os}$ hütőben tároltuk további felhasználásig. A megmaradt tenyészetből tisztított plazmid DNS-t szekvenálásra küldtük, illetve további kísérleteinkben használtuk fel.

\subsection{Fehérjekifejezés $E$.coli sejtekben}

A megtisztított rekombináns plazmidokat a továbbiakban fehérjekifejezésre alkalmas E. coli baktériumtörzsbe BL21(DE3) juttattuk. A sejteket a szaporodásukhoz szükséges tápanyagot (cukor, fehérjék, élesztőkivonat) tartalmazó LB, illetve TB 
tápoldatban (F.2. táblázat) szaporítottuk majd megfelelő sejtsürüség elérése után indukáltuk a fehérje kifejezését izopropil- $\beta$-D-1-tiogalaktozid (IPTG) hozzáadásával. Optimális hőmérsékleten tartva a baktériumok szaporodása meghatározott görbével írható le. Az első 'lag' fázisban (4.4.1. ábra) a bakétriumok alkalmazkodnak a környezetükhöz, felkészülnek az osztódásra, nincs baktérium szám változás. A második fázis a 'log' fázis, ahol baktériumok száma exponenciális növekedésnek indul. Ezt egy stacionárius fázis követi ahol ugyanannyi baktériumsejt képződik, mint amennyi elpusztul, egy kvázi egyensúlyt beállítva a születő és pusztuló baktériumok között. Így a sejtek száma már nem változik. Az utolsó fázisban az egyensúly a pusztuló baktériumok irányába tolódik el, elhanyagolhatóvá válik az újonnan képződő sejtek száma, azaz a baktériumok pusztulása is exponenciális tendenciát mutat.

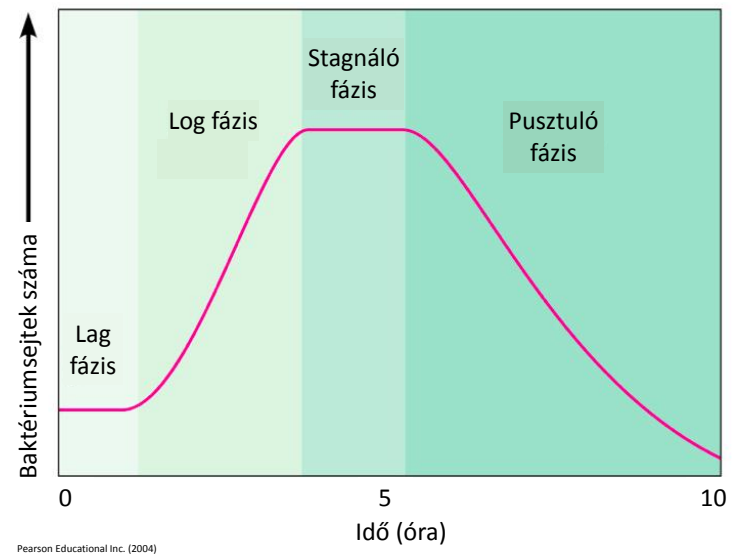

4.4.1. ábra:A baktériumok szaporodási görbéje a tápoldatban, azaz a baktériumsejtek számának ábrázolása az idő függvényében.

A rekombináns fehérje kifejezésének indukálására használatos IPTG-t a logaritmikusan növekvő sejtek szuszpenziójához adtuk. Az indukálás elve az, hogy a plazmid ún. lac operátor régiójához egy represszor fehérje kötődik, megakadályozva a fehérje kifejeződését. Az IPTG ehhez a fehérjéhez kötődve szünteti meg annak gátló hatását. A lac operátor a lac operon szerves része, melynek történeti jelentősége nagy. Ez ugyanis az elsőként felfedezett olyan DNS régió, mely lehetővé teszi a génekről történő átírás és fehérjekifejeződés szabályozását. A lac operont a DNS-ükben tartalmazó baktériumsejtek képesek laktózt használni energiaforrásként, ha a $\beta$ galaktozidáz enzim elbontja azt galaktózra és glükózra. Alapesetben ez az enzim glükóz jelenlétében nem fejeződik ki, de a BL21(DE3) törzsben ezt a szabályozást kiiktatták így a sejtek gazdag tápoldatban is képesek a lac operont müködtetni. Viszont továbbra 
is a laktóz jelenléte indukálja a lac operon müködését, így a célfehérje kifejezését. Ezt a folyamatot használjuk ki amikor a lac operátor régió után beépített fehérje kifejezését indukáljuk. Mivel az IPTG nem természetes vegyület, a sejtek nem bontját azt le, így a fehérjetermelés a sejtben folyamatos lesz - túltermelés. A fehérjekifejezés indukálása után a baktériumsejtek osztódása lelassul.

A fehérjeszintézis indukálása után az optimális idő elteltével a tápoldatban lévő baktériumsejteket lecentrifugáltuk. A tápoldat eltávolítása után a sejteket újraszuszpendálva, a sejtfalat elroncsolva majd ismét lecentrifugálva az oldható fehérjék a felülúszóba kerülnek. Ez az oldat azonban sokféle fehérjét tartalmaz, amiket méretük és töltésük, valamint egyedi tulajdonságaik alapján lehet elkülöníteni. A tisztítási eljárásokat minden fehérjére külön-külön optimalizálni kell.

\subsection{Nagyhatékonyságú folyadék-kromatográfiás elválasztás (HPLC)}

\section{Fehérjetisztítás}

A fehérjék egymástól történő elválasztását több tényező is befolyásolja: méret, alak, töltések, oldhatóság. A fehérjék legkevésbé az izoelektromos pontjuknak megfelelő pH-n oldhatóak, ahol a bruttó elektromos töltésük zérus. Ezen a ponton a fehérjemolekulák közötti elektromos taszítás minimális, így könnyebben aggregálódnak és csapódnak ki az oldatból. Az ionerősség szintén meghatározó tényező: sok globuláris fehérjének növeli az oldhatóságát az ionerösség növekedése, mivel a fehérjék közötti elektrosztatikus vonzás lecsökken a sóból képződő ionok árnyékoló hatása miatt. Ha viszont a sókoncentráció nagyobb, mint 1,0 M, a fehérje kisózódhat az oldatból, azaz mivel a sóból képződött ionok és a fehérje hidratálódása kompetitív folyamat, nagy sókoncentráció mellett a fehérje oldhatatlanná válik.

\section{Kromatográfiás elválasztások}

A kromatográfia alapelve, hogy a mozgó fázisban lévő anyagok állófázison történő átjutásának sebessége különbözik. Ennek oka a fehérjék fizikai és kémiai tulajdonságai közötti különbség. Preparatív kromatográfia esetén az elválasztás a tisztítási folyamat része, és a kapott anyagnak valamilyen felhasználási célja van, szemben az analitikai kromatográfiával, ahol kisebb anyagmennyiségekben jelenlévő 
anyag relatív arányának meghatározása a hangsúlyosabb. Biológia minták preparatív célú elválasztására ioncsere kromatográfiát, méretkizárásos kromatográfiát vagy gélszürést, illetve affinitás kromatográfiát használnak (4.5.1. ábra).

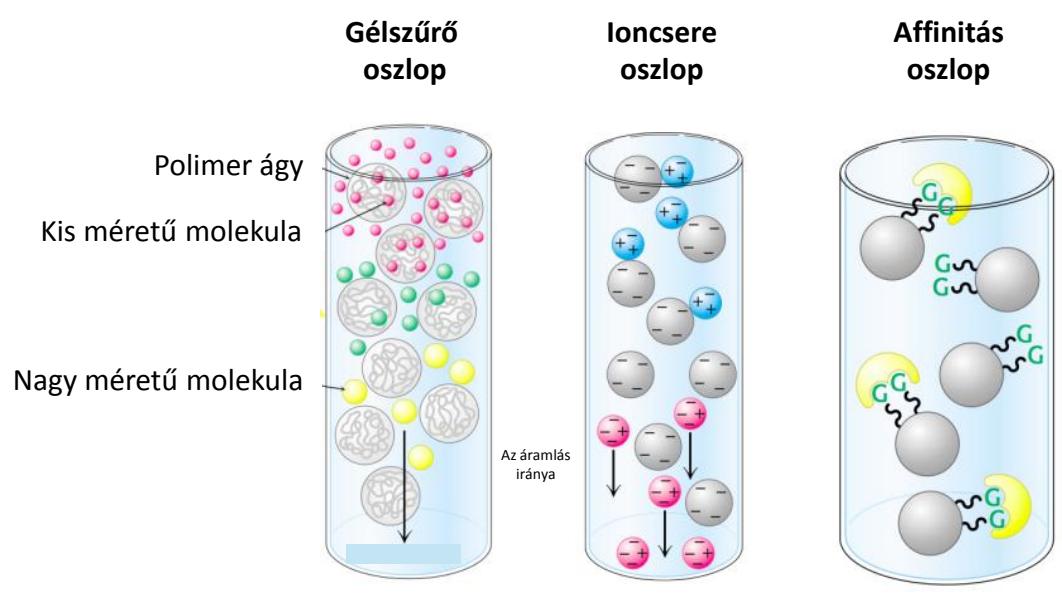

4.5.1. ábra: Gélszürő, ioncsere illetve affinitás oszlopon történő elválasztások sematikus ábrája [88].

Ioncsere kromatográfiás eljárás esetén a töltéssel rendelkező ionok, molekulák (aminosavak, peptidek, fehérjék) kötődnek az állófázis (töltött funkiós csoportokat tartalmazó ioncserélő gyanta) ellentétes töltéssel rendelkező csoportjaihoz. Ha az oszlop töltetét képező gyanta pozitívan töltött csoportokat tartalmaz, akkor anioncseréről, ha pedig a töltet negatív, akkor kationcseréröl beszélünk. A töltetek, illetve az elválasztandó fehérje funkciós csoportjainak sav-bázis erőssége határozza meg a kötődés erősségét, illetve a gyantán térfogategységére eső számuk a kapacitást. A teljesen ionizált erösen savas csoportok, mint pl. a szulfonsav, negatív töltést eredményeznek a szilárd fázisban, aminek révén az erősen képes kötni a kationokat. Az eluálás során az oszlopon megkötött fehérjemolekula cserélödik egy másik töltött ionra, ahol a gyenge savas, illetve bázisos csoportokat tartalmazó gyanták töltése és így a kötő kapacitása erősen függ az eluens oldat pH-jától is.

Méretkizárásos kromatográfia vagy gélszürés esetén a hidrodinamikai átmérő alapján történik az elválasztás. A kisebb molekulák képesek belépni a töltet pórusaiba, lassabb elúciót eredményezve, míg a nagyobbak gyorsabban áthaladnak az oszlopon. Általánosan használt töltetek a dextrán (Sephadex), az agaróz (Sepharose) és poliakrilamid (Biogel). 
Az affinitás kromatográfia leginkább biológiai minták elkülönítésére használt eljárás.

A kölcsönhatás alapja lehet enzim-szubsztrát, antigén-antitest, receptor-ligandum kölcsönhatás. Alapvető célja a célmolekula kizárólagos specifikus megkötése az állófázison, amely eluálás után így tisztán a rendelkezésünkre áll. Az egyes vektorokból olyan, ún. fúziós fehérjékként fejeződnek ki a célfehérjék, melyeknek az N- vagy Cterminális részén egy már jól ismert fehérje található. Ezek a fúziós toldalékok lehetnek pl. enzimek, (mint pl. a glutation-S-transzferáz), vagy egyéb olyan fehérjék (pl. maltózkötő fehérje) vagy peptidrészletek (pl. hexa-, vagy dekahisztidin) melyek szubsztrátjukat, vagy azok analógjait kötik specifikusan és erősen.

Ub-HNH fúziós fehérje kifejezése és tisztítása: A BL21(DE3) fehérjekifejezésre alkalmas kompetens E. coli sejteket transzformáltuk pET26b-Ub-HNH plazmiddal, majd antibiotikum-tartalmú LB tápoldatban szaporítottuk a sejteket $37{ }^{\circ} \mathrm{C}$-on, folyamatos rázatás mellett $(250 \mathrm{rpm} /$ perc $)$ az $\mathrm{OD}_{600}=0,4$ érték eléréséig. Ekkor IPTG hozzáadásával indukáltuk az Ub-HNH fehérje kifejezését (végkoncentráció 1,0 mM), majd további 3-5 órán át szaporítottuk a baktériumokat. Centrifugálással (4000 rpm, 4 ${ }^{\circ} \mathrm{C}, 10$ perc, Sorvall SS34 rotor) választottuk el a sejteket a tápoldattól, majd azokat 30 $\mathrm{ml}$ extraciós pufferben $(50 \mathrm{mM}$ kálium-dihidrogén-foszfát, $100 \mathrm{mM}$ nátrium-klorid, 7 mM 2-merkaptoetanol, $\mathrm{pH}=7,4$ ) szuszpendáltuk fel. Ultrahang segítségével roncsoltuk a sejteket, majd ezután újabb centrifugálással (14000 rpm, 30 perc, $4{ }^{\circ} \mathrm{C}$, Sorvall SS34 rotor) elkülönítettük a sejttörmeléket a felülúszó frakciótól, mely várhatóan a kívánt fehérjét is tartalmazta. A felülúszó frakcióban lévő nukleinsavakat $1 \%$-os sztreptomicin szulfát oldat segítségével kicsaptuk. Centrifugálás után a felülúszó frakciót kétszeresére hígítottuk a megfelelő pufferrel $(50 \mathrm{mM}$ kálium-dihidrogén-foszfát, $7 \mathrm{mM}$ merkaptoetanol, $5 \%$ glicerin, $\mathrm{pH}=7,4)$. Ugyanezzel a pufferrel ekvilibráltuk a 9,5×3,5 cm-es foszfocellulóz (Whatman P11) oszlopot, majd feltöltöttük rá a fehérjénket tartalmazó oldatot. Az elúció 0-1 $\mathrm{M} \mathrm{NaCl}$ gradienssel történt (Akta purifier HPLC, P900 pumpa rendszer, UV900 detektor, FRAC 920 frakció kollektor). Ub-HNH fehérjét a frakciók összeöntése után töményítettük (Amicon Ultracell 10K), majd gélszüréses kromatográfia segítségével tovább tisztítottuk (Superdex 75 PrepGrade 16/60 GE Healthcare, a használt puffer $50 \mathrm{mM}$ kálium-dihidrogén-foszfát, $100 \mathrm{mM}$ nátriumklorid, $\mathrm{pH}=7,4)$. A megtisztított Ub-HNH fehérjével végzett további kísérletek az alábbi pufferekben történtek: MS: 0,1 M ammónium acetát pH 8,0, CD: $10 \mathrm{mM}$ TRIS, $100 \mathrm{mM} \mathrm{NaCl}, \mathrm{pH}=7,4$. 
HUE-HNH fehérje: HUE-HNH fehérje kifejezése a fent leírtak alapján történt. A sejteket $20 \mathrm{ml}$ „A” pufferrel reszuszpendáltuk (50 mM kálium-dihidrogén-foszfát, 300 $\mathrm{mM}$ nátrium-klorid, $12 \mathrm{mM}$ imidazol, $20 \mathrm{mM}$ 2-merkaptoetanol, 30\%-os glicerin, $\mathrm{pH}=$ 7,4), majd ultrahangos roncsolással lizáltuk a sejteket. Centfrifugálás után a felülúszóban lévő nukleinsavakat 1\%-os sztreptomicin szulfáttal távolítottuk el, majd centrifugálás után a felülúszót $2,5 \mathrm{ml} \mathrm{Ni}$-agaróz (His select, Sigma) töltetű oszlopon választottuk el. Az oszlop ekvilibrálása az „A” pufferrel történt, ami még $20 \mathrm{mM}$ imidazolt is tartalmazott. HUE-HNH fehérje eluálását 50, 100, 150, 200 és $250 \mathrm{mM}$ imidazolt tartalmazó pufferrel végeztük. A kromatogram frakcióit összegyüjtve, egész éjszakán át tartó dialízisnek vetettük alá (50 mM kálium-dihidrogén-foszfát, $300 \mathrm{mM}$ nátrium-klorid, $2 \mathrm{mM}$ 2-merkaptoetanol, 30\%-os glicerin, $\mathrm{pH}=7,4$ ).

HUE-HNH hasítása Usp2-cc proteázzal: Az Usp2-cc enzimet ugyancsak BL21(DE3) sejtekben fejeztettük ki, pHUsp2-cc plazmid formájában bejutattva a sejtekbe. A megtisztított HUE-HNH fúziós fehérjét az Usp2-cc proteázzal 10:1 mólarányban emésztettük, majd affinitás kromatográfia segítségével szeparáltuk a fehérjéket (His Select oszlop). A felkötődött fehérjét imidazol gradiens elúcióval mostuk le az oszlopról 15 mM imidazol kezdő koncentrációval. A kívánt fehérjét $50 \mathrm{mM}$-os imidazol koncentrációnál eluáltuk, majd a fehérje tisztaságát 16\%-os Tricin-SDS-PAGE segítségével ellenőriztük.

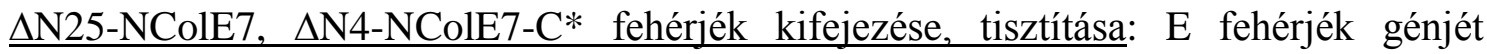
pGEX-6P1 vektorba klónoztuk, azaz GST-fúziós fehérjeként állítottuk őket elő. A fehérjéink génjét tartalmazó plazmidokat fehérjekifejezésre alkalmas BL21(DE3) sejtekbe juttattuk, a transzformált sejteket ampicillin-tartalmú LB táptalajon növesztettük egy éjszakán át $37{ }^{\circ} \mathrm{C}$-on, majd $50 \mathrm{ml}$ ampicillin-tartalmú LB előkultúrából kiindulva $\left(30{ }^{\circ} \mathrm{C}, 250 \mathrm{rpm}, 4\right.$ óra), $650 \mathrm{ml}$ ampicillin-tartalmú LB tápoldatban $\left(30{ }^{\circ} \mathrm{C}, 250 \mathrm{rpm}\right)$ szaporítottuk a sejteket $\mathrm{OD}_{600}=0,6$ értékig. Ezután IPTGt adtunk a baktériumtenyészethez (végkoncentráció $0,1 \mathrm{mM}$ ) a fehérjekifejezés indukálásaa céljából. A tápoldatot $250 \mathrm{rpm}$ sebeséggel $30{ }^{\circ} \mathrm{C}$-on 3 órán keresztül inkubáltuk, majd centrifugáltuk (4000 rpm, $4{ }^{\circ} \mathrm{C}, 10$ perc) és a felülúszót eltávolítottuk. A sejteket PBS pufferrel mostuk (10×PBS puffer: 1,4 M nátrium-klorid, $27 \mathrm{mM}$ káliumklorid, $100 \mathrm{mM}$ dinátrium-hidrogén-foszfát, $18 \mathrm{mM}$ kálium-dihidrogén-foszfát, $\mathrm{pH}=$ 7,3) majd a további felhasználásig $-80{ }^{\circ} \mathrm{C}$-on tároltuk. A fehérjetisztítás első lépéseként 
a $650 \mathrm{ml}$ sejtkultúrából lecentrifugált sejteket felolvasztottuk, majd $40 \mathrm{ml}$ PBS pufferben felszuszpendáltuk, majd ultrahang segítségével roncsoltuk. Ezután centrifugálással (12000 rpm, $4{ }^{\circ} \mathrm{C}, 20$ perc) különítettük el a sejttörmeléket a fehérjét tartalmazó felülúszótól. A GST-fúziós fehérjét tartalmazó felülúszót GST oszlopra töltöttük (GSTPrep FF 16/10), miután ekvilibráltuk az oszlopot PBS pufferrel. A felkötés után ugyanezzel a pufferrel mostuk át a kolonnát, majd redukált glutationt tartalmazó oldattal eluáltuk a felkötődött fehérjéket $(20 \mathrm{mM}$ Tris-HCl, $10 \mathrm{mM}$ redukált glutation, $\mathrm{pH}=8,0)$. Ezután fúziós fehérjét tartalmazó a frakciókat összegyüjtve Prescission proteázzal hasítottuk le a fehérjéinkről a GST fúziós részt. A proteázt a fent leírtakkal megegyező módon baktériumokban állítottuk elő és ugyanúgy GST affinitás kromatográfiával tisztítottuk. A hasítás fehérje:proteáz 7:1 mólarányban történt egy éjszakán át, $4{ }^{\circ} \mathrm{C}$-on. A lehasított GST részt, illetve magát a GST-3C Prescission proteázt GST oszlopra felkötöttük, és a fehérjéinket átfolyó frakcióban gyüjtöttük. Tisztaságukat SDS-PAGE segítségéevel ellenőriztük, amit nem ítéltünk megfelelőnek, ezért egy további ioncsere kromatográfiás elválasztást végeztünk. Kationcserélő

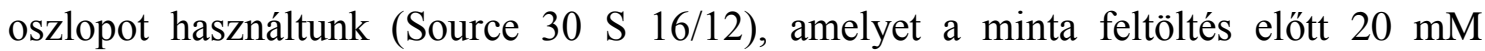
HEPES pH 7,7 pufferrel ekvilibráltunk, majd a minta feltöltés és mosás után, ugyanebben a pufferben lévő növekvő $\mathrm{NaCl}$ koncentrációval gradiens elúciót alkalmaztunk. A fehérjénk 0,33 $\mathrm{M} \mathrm{NaCl}$ jelenlétében eluálódott. A megfelelő frakciókat SDS-PAGE segítségével ellenőriztük, majd azokat összeöntve töményítettük (Vivacell 70) a további kísérletekhez.

Fehérjekifejezés fúziós rész nélkül: $\mathrm{A}$ fenti $\Delta \mathrm{N} 25-\mathrm{NColE7}, \Delta \mathrm{N} 4-\mathrm{NColE7-C}{ }^{*}$ fehérjéket fúziós rész nélkül is előállítottuk: pET21a vektorba ligáltuk a $\triangle \mathrm{N} 25-\mathrm{NColE} 7$ és $\Delta \mathrm{N} 4-$ NColE7 fehérje génjét, majd a fent leírt módon megfelelő baktériumokba jutattuk, kifejeztettük a fehérjéket, majd elkülönítettük a nem kívánt sejttörmeléket. Miután a fehérjét tartalmazó felülúszó frakció a rendelkezésre állt, kationcserélő oszlopra töltöttük fel (Sepharose Fast Flow SP 16/10) az ekvilibráláshoz és mosáshoz szintén 20 $\mathrm{mM}$ HEPES $\mathrm{pH}=$ 7,7 puffert használtunk és az eluáláshoz szintén gradiens eluciót 0-1 $\mathrm{M} \mathrm{NaCl}$. A kromatográfiás csúcsot itt is $0,33 \mathrm{M} \mathrm{NaCl}$ jelenlétében detektáltuk, SDSPAGE alkalmazásával ellenőrizve a frakciókat, egy újabb kationcserés elválasztást végeztük, amely teljes mértékben megegyezett a fent említett kationcserés elválasztással (Source 30 S 16/10 kolonna, „A” puffer: 20 mM HEPES pH = 7,7, „B” puffer: $20 \mathrm{mM}$ HEPES $\mathrm{pH}=7,7+1,0 \mathrm{M} \mathrm{NaCl}$ ). A második kationcsere után a frakciókat SDS-PAGE 
segítségével ellenőriztük, majd a megtisztított fehérjéket összeöntve töményítettük (Vivacell 70).

Ezeket a fehérjéket a szokványos LB tápoldat mellett M9 minimál tápoldatban is előállítottuk és a fenti módon megtisztítottuk. Ezen tápoldatban a baktériumok növekedése lassabb, ezért a $650 \mathrm{ml}$ tápoldatot IPTG hozzáadás után egész éjszakán át, $20{ }^{\circ} \mathrm{C}$-on inkubáltuk $250 \mathrm{rpm}$ sebességü rázatás mellett.

\subsection{Tömegspektrometria (ESI-MS)}

A tömegspektrometria az ionizált atomok, molekulák tömeg/töltés hányadosa alapján történő szétválasztásán alapul (4.6.1. ábra). A mérés alapvető lépései a következők: vákuumban elpárologtatatott és ionizált molekulák oldata gázfázisú ionokat eredményez, ahol az ionok szétválasztása térben és időben az $\mathrm{m} / \mathrm{z}$ hányados alapján történik, majd a különböző $\mathrm{m} / \mathrm{z}$ értékhez tartozó molekulaionokat megfelelő detektorral érzékelik. Többféle ionizálási módszer közül a makromulekulák, fehérjék vizsgálatára a kíméletes ESI (Electrospray Ionization) és MALDI (Matrix Assisted Laser Desorption Ionisation) alkalmazása bizonyult sikeresnek. Az ESI atmoszférikus nyomáson, folyadékfázisból történik. Az elektromos tér hatására töltött apró cseppek jönnek létre, amelyek tovább zsugorodnak az oldószer elpárolgásával, egyre nagyobb töltéssel rendelkeznek, majd gázfázisú ionok képződnek belőlük. A mintabevitel egy vékony kapillárison keresztül történik, ahol alacsony áramlási sebesség mellett viszonylag nagy feszültség hatására $(2-5 \mathrm{kV})$ jön létre az ionizáció.

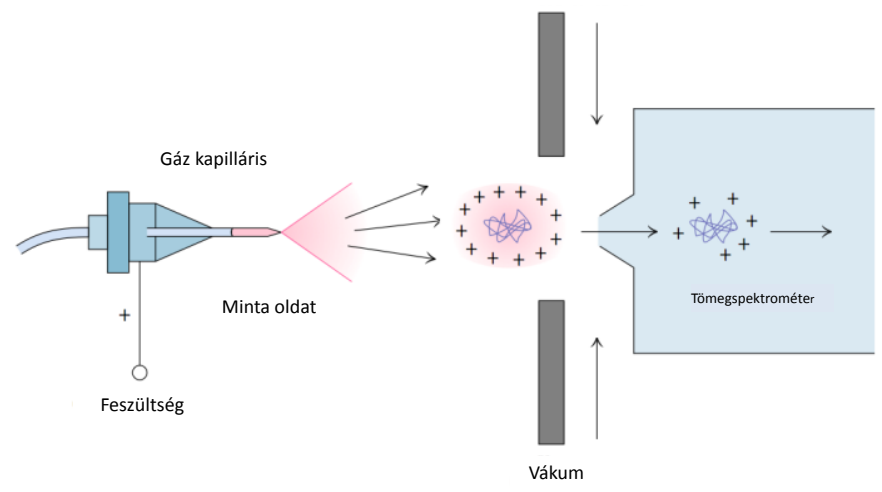

4.6.1. ábra: ESI-MS sematikus ábrája [87]. 
Az alkalmazott feszültség lehet pozitív és negatív. Pozitív-ion módban pozitív töltésü ionok képződnek az alkalmazott pozitív feszültség hatására. A kapilláris végén, a folyadék határfelületén felgyülemlenek a pozitív töltésü ionok, míg a negatív töltésűek a pozitív töltésü kapilláris fala felé vándorolnak. A pozitív töltések miatt fellépő taszító erő kúp formájú folyadékfelületet eredményez. Az alkalmazott magas feszültség miatt a pozitív töltések közötti taszítás nagyobb lesz, mint a felületi feszültség, így a kúp végét töltéssel rendelkező cseppek hagyják el. Az oldószer folyamatosan elpárolog a cseppekből, melyek ezért egyre kisebb méretüek lesznek, azonban a töltésük ugyanakkora marad, majd amikor a taszító erő nagyobb lesz, mint az összetartó erő, kisebb cseppekre esik szét. Ez addig folytatódik, amíg a cseppek átméröje a nanométeres tartományba nem esik. Az ionforrásban előállított ionok feszültség hatására továbbhaladnak az analizátor felé, ahol tömeg/töltés arány szerint elkülönülnek. A nano ESI-MS használatakor, egy vékony kapilláris segítségével történik a minta porlasztása. Az 1-2 $\mu$ m átmérővel rendelkező kapillárisban az áramlási sebesség 20-50 nL/perc, ami egy kisebb elsődleges cseppméretet eredményez. Ez hatékonyabb ionizációt és nagyobb toleranciát biztosít a sószennyeződéssel szemben.

Többféle analizátor közül a repülési idő analizátor (TOF) a legelterjedtebb. A TOF az ionforrástól a detektorig megtett időt rögzíti. A töltéssel rendelkező részecskék elektromos térben a töltésükkel arányos kinetikus energiára tesznek szert. Erötérmentes térbe lépve az azonos kinetikus energiájú, de eltérő tömegű ionok elkülönülnek és eltérő időben (kisebb tömegüek gyorsabban, nagyobbak lassabban) érik el a detektort. A repülési idő az ionforrás-detektor távolság, gyorsító feszültség és a fajlagos tömeg függvénye.

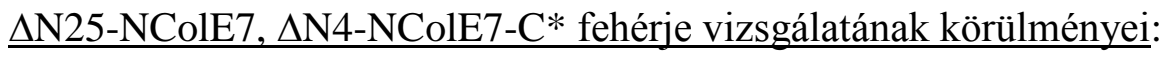

Tömegspektrometriás mérések egy LCT Premier (Waters) nano ESI berendezésben TOF detektorral történtek Dániában (Technical University of Denmark). A berendezés kalibrációja 50\% 2-propanolban feloldott 100 mg/ml CsI-dal történt 600$12000 \mathrm{~m} / \mathrm{z}$ tartomány között. $3 \mu \mathrm{l}$ fehérjeoldatot $\mathrm{Au} / \mathrm{Pd}$ borítású boroszilikát üvegkapilláris tüből (Prexon) jutattuk a készülékbe. A fehérje koncentrációja 10-20 $\mu \mathrm{M}$ között volt $100 \mathrm{mM}$ ammónium-acetát oldatban (Sigma). A tü feszültsége $1200 \mathrm{~V}$, a 


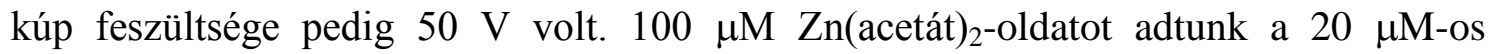
fehérjeoldathoz 1:1 mólarány eléréséig.

\subsection{Cirkuláris dikroizmus spektroszkópia}

A cirkulárisan polarizált fény és optikailag aktív anyag kölcsönhatásán alapuló cirkuláris dikroizmus (CD) spektroszkópiai eljárás királis molekulák, mint pl. a fehérjék szerkezetére, illetve kölcsönhatásaik során bekövetkező szerkezetváltozásukra nézve ad információt. A jobbra és balra cirkulárisan poláros fénysugarat a királis minta különböző mértékben nyeli el. Ezt a különbséget, vagy a kilépő fénysugár ellipticitását ábrázolva a hullámhossz függvényében kapjuk a CD spektrumot. A biomolekulák nagy részében találunk egy vagy több kiralitás-centrumot, ami az optikai aktivitást eredményezi. A fehérjék szerkezetvizsgálatának esetében föként az UV hullámhossztartomány informatív. 180-250 nm között az amid-kromofórok elnyelési tartományában a spektrum alakja ezen csoportok egymáshoz viszonyított helyzetére jellemző. Azaz a másodlagos szerkezetre ( $\alpha$-hélix, $\beta$-redö, stb.) nézve kapunk információt. Legnagyobb intenzitású CD jele az $\alpha$ hélix szerkezetü fehérjéknek van, mivel a kromofórok párhuzamos állása a legnagyobb erősítési effektust hozza létre. A közeli UV tartományban 250-350 nm között megjelenő sávokat a konjugált kettős kötést, és/vagy aromás gyürüket tartalmazó oldalláncokat, illetve azok egymáshoz viszonyított helyzetét határozza meg. Azaz a fehérje harmadlagos szerkezetére nézve is nyerhetünk információt ezzel az eljárással.

A CD méréseket eleinte Jobin-Yvon CD6 müszeren végeztük, majd az UV tartományban megbízhatóbb SRCD (Synchrotron Radiation Circular Dichroism) mérésekeket végeztünk az ASTRID szinkrotonhoz épített CD spektroszkópon Dániában. (University of Aarhus, Denmark). Az összes spektrumot 1 nm-es léptékben, 2 másodperc integrációs idővel $0,1 \mathrm{~mm}$-es kvarc küvettában (SUPRASIL, Hellma GmbH, Germany) 175-260 nm hullámhossz tartományon mérte a témavezetőm. A mért komponenseket Tris-HCl pufferben oldottuk fel. Az alkalmazott pH 7,4 volt. A pH-t $\mathrm{HCl}$ és $\mathrm{NaOH}$ segítségével állítottuk be. Az alkalmazott fehérjekoncentráció $\sim 1,0 \times 10^{-5}$ M volt. 


\subsection{Röntgen krisztallográfia}

\section{Fehérje-kristályosítás}

Egy fehérje 3D szerkezetének megfejtéséhez annak kikristályosításán keresztül vezethet az út. A kristályosítás csak megtisztított, szennyeződésektől mentes fehérjéből lehetséges. A fehérjeoldatból olyan egykristályt kell növeszteni, amely alkalmas a röntgen-sugárzás diffrakcióját előidézni. A fehérje tulajdonságain túl is sok tényező hat a kristály kialakulására: $\mathrm{pH}$, fehérje-koncentráció, hőmérséklet, hozzáadott sók, kicsapószerek, stb. A pH változása módosítja az oldalláncok töltését, ezzel magát a szerkezetet, de a molekulák egymás közötti kölcsönhatásait, illeszkedését is. Kicsapószerként az ammónium-szulfátot és a polietilén-glikolt használják széles körben.

A fehérjék kristályosítására legelterjedtebben a gőzdiffúzió elvén alapuló módszereket alkalmazzák, ezen belül is ülő-, és függőcsepp eljárások különíthetők el. Mindkét esetben a csepp tartalmazza a megtisztított fehérjét, puffert, ami a tartály alján magasabb koncentrációban jelenlévő puffer-kicsapószer oldattal egyensúlyba kerül. A rendszer légmentes összeállítása után ugyanis a cseppböl vízmolekulák lépnek ki az egyensúly beálltáig.

A fehérjekristályosítás fázisdiagramja (4.7.1. ábra) jól szemlélteti, hogy a fehérje és a kicsapószer koncentrációja hogyan befolyásolja a kristály növekedését. A fehérje oldhatósági (telítési) görbéje határolja el egymástól az alul-, és túltelített állapotot. Az alultelített állapotban spontán gócképződés nem indul el, a fehérje oldott állapotban van. A telített állapotot egy kétdimenziós oldhatósági görbe jellemzi, amelynek mentén a spontán gócképződés szintén nem indul meg, a hozzáadott kristály nem oldódik vissza és nem is növeli méretét. A metastabilis túltelített zónában sincs gócképződés, ugyanakkor a hozzáadott kristály növekedésnek indul, míg a labilis túltelített zónában már a gócképződés is megjelenhet. A leginkább túltelített zónában amorf csapadék válik ki, amely nem kedvez a kristálynövekedésnek. 


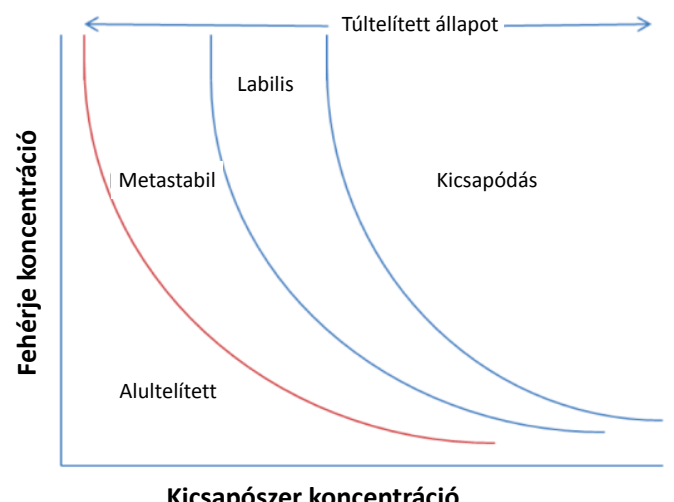

4.7.1. ábra: Fehérjére vonatkozó fázisdiagram.

\section{Szerkezet analízis}

Szabályos fehérje egykristály elöállítása meglehetősen bonyolult feladat. Sok száz különböző körülmény párhuzamos beállítása mellett, majd a bíztató eredményt mutató oldatösszetételek további optimalizálása révén juthatunk el olyan kristályokhoz, melyek képesek olyan röntgen-diffrakciót elöidézni, melyből megfejthetjük a molekula szerkezetét. Ahhoz, hogy a fehérje molekula szerkezetét atomi szinten láthassuk, olyan sugárzásra van szükség amelynek hullámhossza az atomok közötti távolsághoz hasonló (0,1 nm, azaz 1 Å hullámhosszúságú röntgen sugárzás). Egyetlen molekulából származó diffrakció nagyon gyenge lenne, ahhoz hogy számottevő információra tehessünk szert belöle. Ezért szükséges jól rendezett, háromdimenziós kristály elöállítása ahol sok molekula rendeződik kristállyá. Minél nagyobb és jobban rendezett a fehérjekristály, annál nagyobb szögü és felbontású röntgen-diffraktogramot eredményez, ami a szerkezet megfejtését könnyebbé teszi. Mivel a röntgen-sugárzás diffrakciója az elektronokon jön létre, ezért a szerkezet meghatározása a röntgen-diffraktogramból számítható elektronsürüség térkép alapján történik. A kristály úgy viselkedik, mint egy háromdimenziós rács, ami a konstruktív és destruktív interferencia effektusokat adja a diffrakciós mintázatban. Ez a detektoron, diszkrét pontokként jelenik meg. Minden egyes reflekszió információt hordoz az összes atomról a szerkezetben és fordítva, minden atom hozzájárul minden egyes reflekszió intenzitásához. Mint minden elektromágneses sugárzásnak, a röntgen-sugárzásnak is van hullámtermészete, azaz amplitúdója és fázisa. Ahhoz, hogy a diffrakciós mintázat értelmezhető legyen, mindkét információra szükség van az összes reflekszióra vonatkozóan. Azonban a fázisra vonatkozó információk elvesznek az adatgyüjtés során. Az elektronsürüség térkép 
kiszámítása után juthatunk hozzá a fázisokra vonatkozó adatokhoz. A diffrakciós adatokból először is meg kell határozni a kristály szimmetriáját, cella paramétereket, a kristály orientációját és a felbontás határát. Ehhez fontos, hogy a kristályt $\sim 1$ fokonként forgatva a röntgenforrás előtt rögzítésre kerüljön a diffrakció. A kristály szimmetriájától függően ez 30-180 fok tartományban változik. A szerkezet vizualizálásához a fázisprobléma megoldása vezet el, amire a makromolekulák esetén leggyakrabban két módszert használnak. Az első lehetőség a molekula-helyettesítés módszere, ami akkor használható, ha létezik már hasonló fehérjére megfejtett kristályszerkezet. Ilyenkor a már létező molekulaszerkezet segítségével finomítjuk az új adatsort, mindaddig, amíg megfelelő egyezést nem kapunk. Ha erre nincs mód, akkor az ún. izomorf helyettesítés módszere nyújt segítséget, ahol specifikus helyekre egy vagy több nehézatomot építenek be. A nehézatomok elektronsürüsége nagyobb, így mérhető intenzitáskülönbséget okoznak a diffrakciós mintázatban.
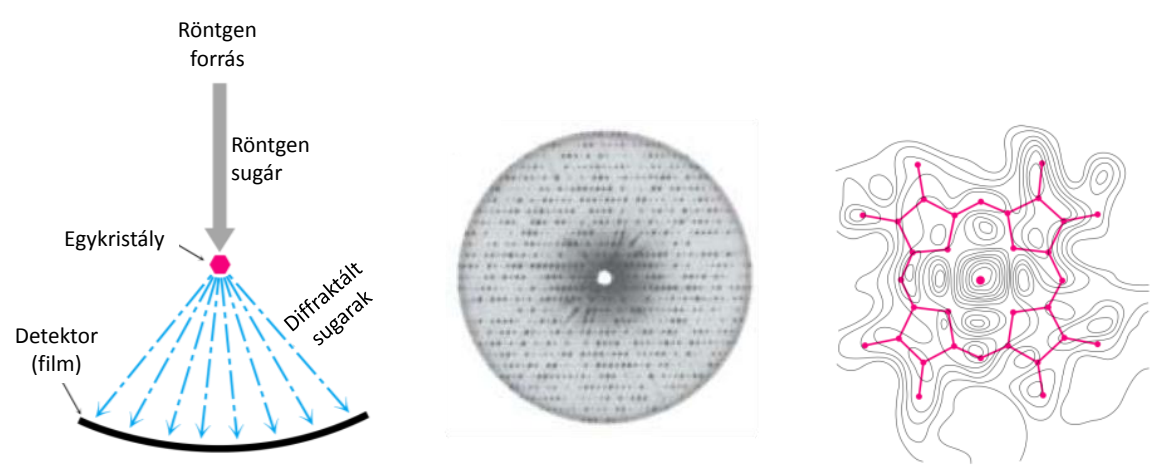

4.7.2. ábra:A röntgen-sugarak szóródása a fehérje egykristályon, az abból származtatható röntgendiffraktogram illetve az elektronsürüség térkép látható a fenti ábrán [88].

A modell építésénél az elektronsürüség-térképből nyerünk információkat az atomi koordinátákra nézve, ami egyszerübb a molekula helyettesítéses módszer alkalmazásakor, mivel már rendelkezésre állnak közelítő atomi koordináták. Először a fehérjeváz illesztése történik meg, majd ha a felbontás lehetővé teszi, akkor a pontos szekvencia szerinti oldalláncokat építjük fel. A részletek mélységének vizualizálása függ a felbontástól és a fázismeghatározás minőségétől. Ha már egy elsődleges modell a rendelkezésünkre áll, akkor annak finomítása a következő lépés, ahol a fázisok finomítása egy jobban definiált elektronsürüség térképet és így pontosabb modellt eredményez. Ezen szakasza a szerkezetmegfejtésnek aprólékos munka, ami vagy eredményez jobb illeszkedést vagy nem. Mindenestre az illeszkedés mértékét jellemző 
$\mathrm{R}$ faktornak, ami a modell és a bevitt adatok közötti egyezést írja le, 25 \% alattinak kell lennie. Minél alacsonyabb az $\mathrm{R}$ faktor, annál pontosabb illesztésröl, és szerkezetmeghatározásról beszélhetünk (4.7.2. ábra).

A fehérje egykristály előállítása dániai tanulmányutam során (University of Copenhagen) történt gyári kristályosító teszt-sorozat (JCSG+, PACT (Qiagen), Index (Hampton Research)) felhasználásával a $\Delta \mathrm{N} 4-\mathrm{NColE7}-\mathrm{C}^{*}$ és a $\Delta \mathrm{N} 25-\mathrm{NColE7}$ mutáns fehérjék esetében. A kristályosítás során ülőcsepp módszert alkalmaztunk, ahol Oryx 8 folyadékkezelő robot (Douglas Instruments) segítségével állítottuk össze az MRC-2 csepplemezeket (Douglas Instruments ). A végleges csepptérfogat 0,3 $\mu 1$ volt 3:1 és 1:1 fehérje: kicsapószer arányban. A fehérje egykristályt JCSG+ teszt-sorozat A1 helyén detektáltuk. A kristály $28 \mathrm{mg} / \mathrm{ml}$-es fehérje 1:1 fehérje:kicsapószer aránynál nőtt, ahol a kicsapószer összetétele a következő volt: $0,1 \mathrm{M}$ lítium-szulfát, $50 \mathrm{mM}$ nátrium-acetát $\mathrm{pH} 4,5,25 \%$ m/v PEG 400. A kristályt az összeállítást után egy hónappal detektáltunk szobahőmérsékleten.

A röntgen diffrakciós adatgyüjtés Svédországban (MAX LAb, Lund) zajlott. A fehérjekristályt folyékony nitrogén segítségével lefagyasztottuk. Az adatgyüjtés 1,6 $\AA$ felbontásig történt (F.3. táblázat). Az adatok indexelése, integrálása, az XDS, illetve XSCALE program segítségével történt. A szerkezet megfejtése a MOLREP (CCP4), molekula helyettesítéses módszerrel a Refmac5 és Coot (Emsley) programok alkalmazásával, dán együttműködő partnereink segítségével, Tóth Eszter Msc hallgató részvételével történt.

\subsection{Magmágneses rezonancia spektroszkópia (NMR)}

Az NMR spektroszkópiát egyre elterjedtebben használják a makromulekulák oldatbeli szerkezetének meghatározására. A mágneses momentummal rendelkező magok mágneses térben, eredő spinjük értéke által meghatározott (2I+1) számú, különböző energiájú állapotot vehetnek fel. Mágneses rezonanciának az ezen energiaszintek közötti átmenetet nevezzük, amely egy megfelelő energiájú eletromágneses sugárzás elnyelése által lehetséges (4.8.1 ábra). Az NMR 
spektroszkópia alkalmas lehet a makromulekulák szerkezetének vizsgálatára, illetve azok dinamikai sajátságainak jellemzésére.

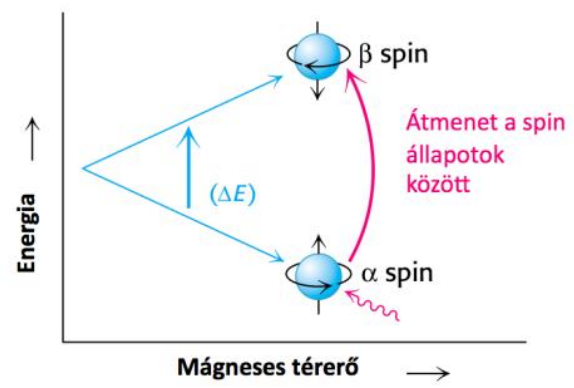

4.8.1. ábra: Különböző energiaértékekhez tartozó spinállapotok a mágneses momentummal rendelkező magok esetében. Az energiakülönbség a mágneses térerö függvényében változik [88].

Az NMR mérésekhez szükséges jelzett fehérjét ${ }^{13} \mathrm{C}$-t, illetve ${ }^{15} \mathrm{~N}$-t tartalmazó ún. M9 minimál tápoldatból állítottuk elő (5.3.3. fejezet). A fehérje kitermelése ilyen körülmények között: $500 \mathrm{ml}$ tápoldatból 2,3 mg $\Delta \mathrm{N} 4-\mathrm{NColE7}{ }^{*}$ A mérések $140 \mu \mathrm{l}, 9$ $\mathrm{mg} / \mathrm{ml}$ fehérjekoncentráció, $15 \mathrm{mM} \mathrm{NaCl}$ koncentráció mellett, 95\% HEPES-D18 oldószerben ( $\mathrm{pH}=7,12)$ történtek. A spektrumokat $500.13 \mathrm{MHz}$-en müködő Bruker Avance DRX 500, NMR készüléken rögzítettük szobahőmérsékleten.

\subsection{Fluorimetria}

Az élő szervezetekben előforduló szabad $\mathrm{Zn}^{2+}$-ionok vizsgálatára számos fluoreszcencia -alapú cink-próbát fejlesztettek ki, amelyek közül a legnépszerübbek a kinolin-egységet tartalmazó molekulák, mint pl. a TSQ, azaz a 6-metoxi-(8-p-toluolszulfonamid)-kinolin és származékai. Ezek a molekulák 2:1 arányú komplexet képeznek $\mathrm{Zn}^{2+}$-ionnal 4 nitrogén donoratom koordinációján keresztül. A 4.9.1. ábra ennek a komplexnek a szerkezetét szemlélteti.

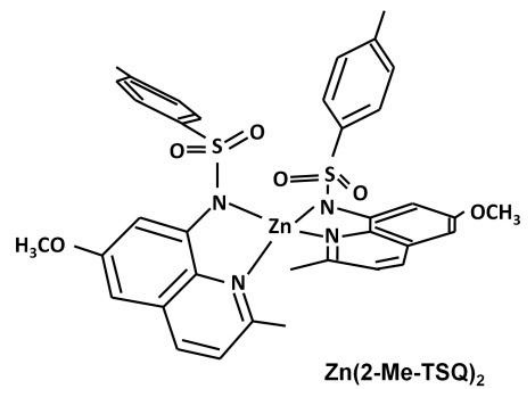

4.9.1. ábra: A TSQ metilezett származéka, $\mathrm{Zn}^{2+}$-ionnal alkotott 2:1 komplexben. 
Az általunk használt fluorofor a fenti TSQ vegyület sav származéka (TFLZn-próba), amely vízoldható vegyület és más kationokkal szemben nagy $\mathrm{Zn}^{2+}$-szelektivitást mutat. Affinitása a $\mathrm{Zn}^{2+}$-ionok iránt elegendően nagy biológiai körülmények között lévő szabad $\mathrm{Zn}^{2+}$-ion megkötéséhez $\left(\mathrm{K}_{\mathrm{d}} \sim 20 \mu \mathrm{M}\right)$, nem elég nagy viszont, a fehérjékben koordinálódott $\mathrm{Zn}^{2+}$-ion elvonásához. $\mathrm{Zn}^{2+}$-ion jelenléte nélkül a TFLZn kis fluoreszcenciát mutat, míg $100 \mu \mathrm{M} \quad \mathrm{Zn}^{2+}$-ion jelenlétében mintegy 100-szoros intenzitásnövekedés tapasztalható. A gerjesztési és emissziós spektrum maximuma rendre $360 \mathrm{~nm}$ és $498 \mathrm{~nm}$. 


\section{Kísérleti eredmények és értékelésük}

\subsection{A HNH motívum előállítása és vizsgálata}

Elsőként a colicin E7 C-terminális katalitikus központját alkotó HNH motívum előállításával foglalkoztunk, mivel irodalmi adatok áttekintése alapján (3.3.2. fejezet) feltételeztük, hogy a nukleáz aktivitás ennek a motívumnak tulajdonítható.

\subsubsection{A HNH motívum génjének előállítása}

A colicin E7 fehérje nukleáz doménjét (NColE7) kódoló DNS szakaszt, plazmid vektorba ágyazva (pQE70-NColE7/Im7), egy taiwani kutatócsoporttól kaptuk meg [55]. A C-terminális HNH motívum génjét (5.1.1.1. ábra) e DNS szakaszról PCR segítségével sokszorosítottuk. Ehhez elsőként megfelelő primereket terveztünk, figyelembe véve olyan lépéseket is, amelyek későbbi munkánkban segítettek.

$$
\begin{aligned}
& \text { NCOI } \\
& \text { 5' GCCATGGTTTCAGGGAAGAGAACTTCATTCGAGCTTCATCATGAGAAGCCGATCAGCCAAAATGGTGGTGTC } \\
& \text { 3' CGGTACCAAAGTCCCTTCTCTTGAAGTAAGCTCGAAGTAGTACTCTTCGGCTAGTCGGTTTTACCACCACAG } \\
& \text { TATGATATGGATAACATCAGCGTGGTAACACCTAAAAGGCATATTGATATTCACCGAGGTAAATAGTCGAC3' } \\
& \text { ATACTATACCTATTGTAGTCGCACCATTGTGGATTTTCCGTATAACTATAAGTGGCTCCATTTATCAGCTG5' }
\end{aligned}
$$

5.1.1.1. ábra: $A$ colicin $E 7$ HNH motívumát kódoló DNS szakasz. Félkövérrel és aláhúzva a PCR-hez szükséges primerpár szekvenciája látható. Kék (NcoI) illetve lila (SalI) színnel a restrikciós endonukleázok által felismert szekvenciát, háromszöggel a hasítási helyeiket, míg szürke háttérrel a fehérjeszintézis végét jelentő STOP kódot jelöltük. Az 5' $\rightarrow 3^{\prime}$ primerben két további nukleotid beépítésére került sor, mivel a fehérjekód az NcoI hasítási hely ATG (kék) bázishármasától kezdődik, ami egy metionin aminosavat kódol. Ez egy eltolódott olvasási keretet és így egy mutáns fehérjét eredményezne. A beépített TT nukleotid (szürke) GTT kóddal, azaz egy N-terminális Val aminosavval egészítik ki az eredeti 42 tagból álló motívumot. Így a fehérje szekvenciája a következő lesz: $\mathrm{MV}_{534}$ SGKRTSFELHHEKPISQNGGVYDMDNISVVTPKRHIDIHRGK $_{576}$

A PCR sikerességét agaróz gélelektroforézissel ellenőriztük. A HNH motívum génjét 129 nukleotid alkotja, amihez hozzáadódnak a primerekben szereplő toldalék szekvenciák (restrikciós helyeket kódoló részek, stop kód). Ezért a 143 bázispár (bp) 
hosszúságú termék sikeres reakció esetén, a 100 és a 200 bp hosszúságú marker DNS jelek között detektálható (5.1.1.2. ábra).

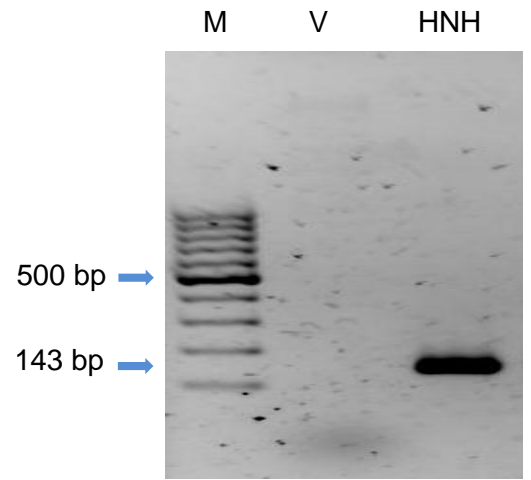

5.1.1.2. ábra: A HNH motívum génjének PCR terméke (3.oszlop) 1,5\%-os agaróz gélen futtatva. Az első oszlopban 100 és 1000 bp között, a 100 bázispáronként elkülönülő marker jelek láthatók (M). Az 500 bp méretủ marker a többinél intenzívebb jelként a könnyebb azonosíthatóságot teszi lehetővé. A második oszlopban templátot nem tartalmazó vak minta látható $(\mathrm{V})$.

\subsubsection{A HNH motívum génjének beépítése cirkuláris DNS molekulákba}

A PCR segítségével előállított, agaróz gélen ellenőrzött HNH motívum génjét elsőként pTZ57R klónozó vektorba (F.4. ábra) építettük be a szekvencia ellenőrzése céljából. A restrikciós enzimek nélküli (T/A) klónozás ennél a kisméretü DNS-nél biztonságosabbá teszi a vektorba történő ligálást.

A transzformálás során (részletesen lásd a 4.3. fejezetben) a pTZ57R-HNH plazmidot DH10B E. coli baktériumtörzs kompetens sejtjeibe juttattuk, amely ampicillinrezisztenciát biztosított a sejteknek. A megfelelő táptalajon (ampicillin-tartalmú LB) történő szaporítás után, egyetlen baktériumtelepről vett mintából kiindulva, $4 \mathrm{ml}$ tápoldatban (LB amp) tenyésztett kultúrából elegendő mennyiségü DNS-t izoláltunk a DNS szekvencia ellenőrzése céljából. A szekvenálás igazolta a nukleotid sorrend helyességét.

Az 5.1.1.1. ábrán látható primerek lehetővé tették, hogy a $H N H$ gént egy jól szabályozott, fehérjekifejezésre optimalizált plazmidba is beépíthessük. A sokszorosított pTZ57R vektorból az inzertet (HNH motívum génjét) az NcoI, SalI restrikciós endonukleázok segítségével kihasítottuk. Ezzel párhuzamosan a pBAD24 vektort is elhasítottuk ugyanezzel a két enzimmel, majd a kihasított rész helyére, DNS ligáz enzim segítségével beillesztettük a célszekvenciát. 
A pBAD24-HNH vektort fehérjekifejezésre alkalmas BL21(DE3) E. coli baktériumtörzsbe juttattuk. Ezen vektor alkalmazásával a fehérjekifejezés arabinóz hozzáadásával indukálható. A fehérje kifejeződése az NcoI hasítási helyben (CCATGG) lévő ATG kódtól indul, így egy 43 aminosavból álló fehérje képződik. A fehérje termelését csökkentett alapszinten tartó pBAD24 vektor, az esetleges toxikus hatás miatt előnyös. Az irodalmi adatokból kiderül [88], hogy akár egy molekula NColE7 kifejeződése is toxikus a baktériumsejt számára, ezért az csak immunitásfehérje $(\operatorname{Im} 7)$ jelenlétében fejezhető ki. Ez az eljárás azonban esetünkben nem volt alkalmazható, ugyanis az $\operatorname{Im} 7$ kötőhely a HNH motívumon kívüli részen található [89].

A termelődött fehérjét SDS poliakrilamid gélelektroforézis (PAGE) segítségével próbáltuk kimutatni, azonban a gélen a fehérje nem látszódott. Ennek oka lehet, hogy a kisméretü fehérjét a baktérium proteáz enzimei a termelődéssel párhuzamosan le is bontották. Ezért a következő lépésben a HNH motívumot kerülő úton, egy nagyobb fehérjével történő fúziója, majd a fehérjeképződés után a fúziós rész lehasítása révén próbáltuk meg elöállítani.

\subsubsection{Az ubikvitin (Ub) fúziója a HNH motívumhoz}

A pET vektorcsalád tagjai szintén fehérjekifejezésre alkalmas, IPTG-vel indukálható cirkuláris DNS molekulák. Az eredeti pET26b vektorba (F.5. ábra) BamHI, NdeI restrikciós helyeket felhasználva T4 DNS ligáz segítségével beépítették az ubikvitin fehérje (Ub) génjét [90]. E folyamat pET26b-Ub vektort eredményezett, amelyet BL21(DE3) E. coli törzsbe tartozó baktériumsejtekbe juttattunk, melyeket a megfelelö közegben elszaporítottunk (kanamicin anitbiotikum tartalmú LB tápoldatban).

A HNH-motívum génjét, az Ub génjének 3'-végéhez kapcsoltuk. A motívum előállítását úgy terveztük, hogy a fúziós fehérje termelődése után az ubikvitint szükség esetén egy specifikus proteázzal (pCG1) lehasíthassuk a HNH motívumról. Ez a folyamat "in vivo" is megoldható, mivel rendelkezésünkre állt egy olyan plazmid, mely a pCG1 proteázt kódolta [90]. Így a baktériumsejtekbe a specifikus hasítást végző proteáz plazmidját is bejuttattuk. Párhuzamos fehérjekifejezést indukálva a $\mathrm{HNH}$ fehérje megjelenését vártuk. 
A proteázzal történő hasítás során az Ub és a HNH szekvenciák közé beékelődött két új aminosav (SM) a HNH motívum N-terminális végén maradt. Ezek az aminosavak a képződő fehérje fémionkötő képességét várhatóan nem befolyásolják.

A vektorba beépített DNS szakasz nukleotid-szekvenciája a 5.1.3.1. ábrán látható, az ez alapján termelődő fehérje aminosav-sorrendjével együtt.

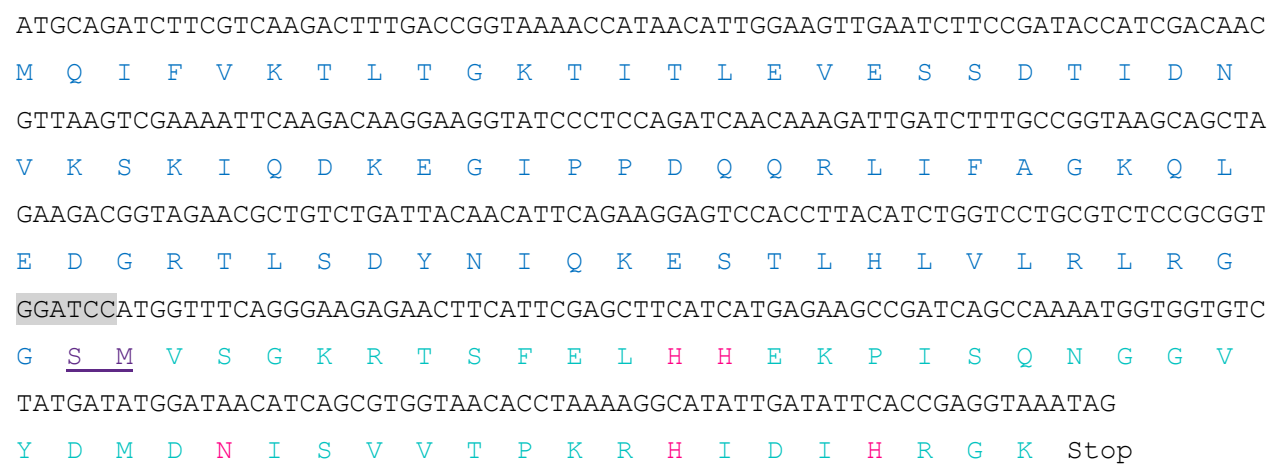

5.1.3.1. ábra: Az Ub-HNH fúziós fehérjét kódoló DNS szekvencia balról jobbra 5 ' $\rightarrow 3$ ' irányban, alatta a bázishármasokhoz tartozó kódolt aminosavak mutatják az Ub-HNH fehérje aminosav-sorrendjét. Lila színnel és aláhúzással jelöltük a specifikus proteáz hasítás után a HNH motívumon maradt aminosavakat (SM), a HNH motívum szekvenciájában megőrződött aminosavakat pedig ciklámen szín jelzi. Szürke háttérrel kiemelve BamHI restrikciós hasítási szekvencia látható.

A beépült két aminosav következtében 45 aminosavból álló $\mathrm{HNH}$ motívum (5102,7 Da) fúziója a 76 aminosavból álló ubikvitinhez (8556,7 Da), tehát egy 13641,4 Da méretü, 121 aminosavat tartalmazó (Ub-HNH) fehérjét eredményez [96].

\subsubsection{Ub-HNH fúziós fehérje kifejezése}

Az Ub-HNH fúziós fehérjét BL21(DE3) E. coli sejtekben fejeztük ki. Az UbHNH termelődését és a proteáz hasításának eredményét SDS-PAGE, illetve tömegspektrometriás módszerrel ellenőriztük. Ehhez megfelelő pórusméretű gélt kellett készíteni, amely alkalmas ilyen kis molekulatömegü fehérje kimutatására. Amint azt az 5.1.4.1. ábra mutatja, a sejtkivonatban megjelenik egy intenzív sáv az Ub-HNH fehérje (1. oszlop) méretének tartományában. A proteáz alkalmazásakor (2. oszlop) ez a sáv eltünik és helyette a $6,5 \mathrm{kDa}$ méretü marker jel alatt jelent meg egy intenzív sáv. 
Mindez arra utal, hogy az Ub-HNH fehérje és proteáz is kifejeződött és az hatékonyan müködött.

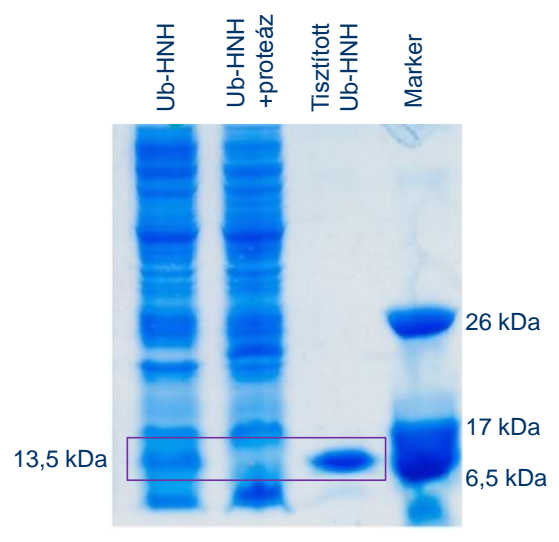

5.1.4.1. ábra: Az Ub-HNH kimutatása SDS-PAGE segítségével proteáz nélkül kifejezve (1.oszlop), valamint az ubikvitin-specifikus pCG1 proteáz párhuzamos kifejezésének és müködésének szemléltetése (2.oszlop).

A továbbiakban a képződött fehérjék kimutatása volt a célunk. Mivel az ubikvitin $(8,7 \mathrm{kDa})$ SDS-PAGE képen nem a molekulatömegének megfelelö helyen jelenik meg, hanem épp a 6,5 kDa markerjel alatt, kizárólag poliakrilamid gélen történő elektroforézissel nem dönthető el, hogy a proteázzal történő hasítás eredményeként az Ub és a HNH is jelen van-e a sejtkivonatban. Ennek ellenőrzésére tömegspektrometriás mérést végeztünk. A tömegspektrum alapján igazoltuk az ubikvitin jelenlétét, azonban a HNH motívumot nem tudtuk kimutatni (5.1.4.2. ábra), tehát a sejt azt valószínúleg ebben az esetben is lebontotta.

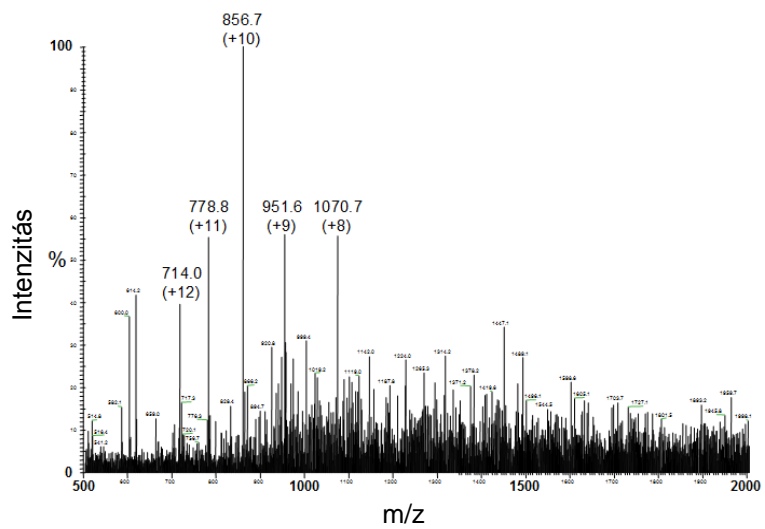

5.1.4.2. ábra: Az Ub-HNH fúziós fehérjét és a pCG1 proteázt kifejező sejtkivonat ESI-MS spektruma, ahol csak az Ub fehérje jelenléte igazolható $\left(\mathrm{M}_{\mathrm{r}}=8556,7 \mathrm{Da}\right)$. 


\subsubsection{Ub-HNH fúziós fehérje tisztítása}

A fentiek alapján a pCG1 a proteáz enzimmel párhuzamosan kifejezve elhasította az Ub-HNH fehérjét, majd a sejtek a $\mathrm{HNH}$ részt lebontották. A HNH motívum előállításához vezető következő lépés így az Ub-HNH fehérje és az ubikvitinspecifikus proteáz külön-külön történő előállítása, tisztítása, majd ezt követően a sejten kívüli hasítás és újabb tisztítás kivitelezése lett volna. Mivel ez hosszadalmas és bonyolult feladatnak ígérkezett, elöször az Ub-HNH fehérje nagymennyiségü kifejezését kezdtük el további vizsgálatok céljából. A fúziós fehérje tisztítását két lépésben végeztük. Elsőként egy foszfocellulóz, majd egy gélszürő oszlopon választottuk el a fehérjét a baktérium egyéb fehérjéitől. $\mathrm{E}$ folyamat $25 \mathrm{mg}$ tiszta UbHNH-t eredményezett egy liter tápoldatból. A második tisztítási lépés, azaz a gélszüréses oszlopon végzett elválasztás kromatogramja, illetve a frakciókhoz tartozó SDS-PAGE gél képe az 5.1.5.1. ábrán látható. A gélképen egy fehérje jelenléte detektálható az Ub-HNH 13641,5 Da molekulatömegének megfelelően.
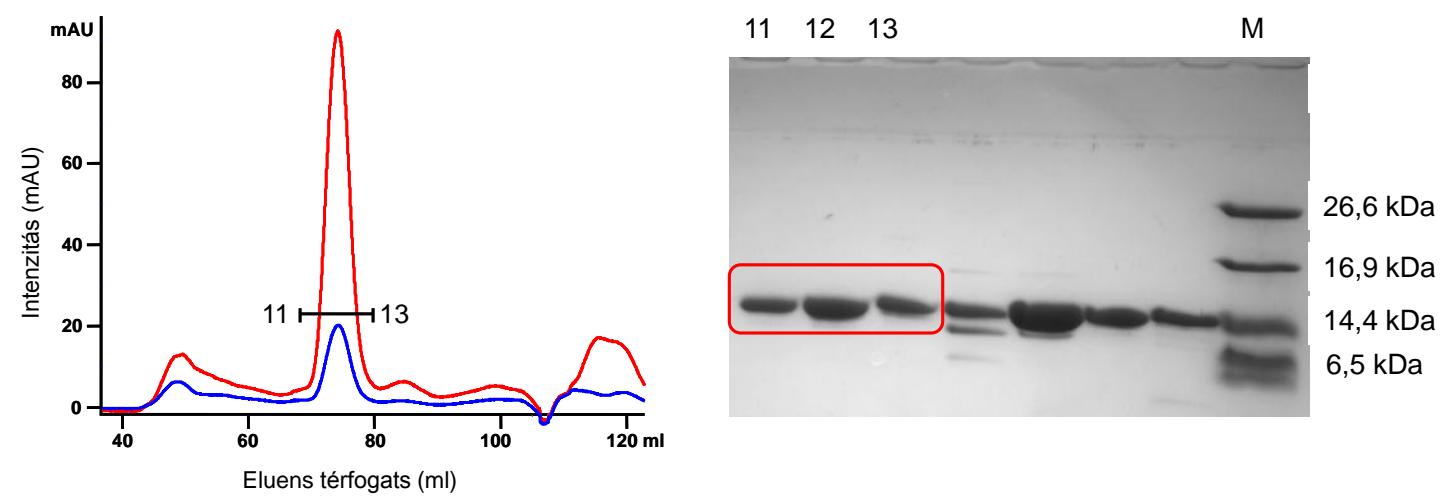

5.1.5.1. ábra: $\mathrm{Az}$ Ub-HNH második tisztítási lépésének kromatogramja (Superdex 75 oszlop), illetve a frakciókat ábrázoló SDS-PAGE gél képe. A kromatogramon a fekete szakasz jelöli 10, 11, 12 frakciókat. A gélen két tisztítás eredménye látható, ahol piros keretes rész jelöli a megfelelő frakcióhoz tartozó mintákat. Az adatgyüjtés két hullámhosszon történt 280 nm (kék), 236 nm (piros).

\subsubsection{Ub-HNH $\mathrm{Zn}^{2+}$-kötésének vizsgálata}

Egy ilyen nagy mennyiségben kifejeződő fehérje nem lehet toxikus a sejtek számára, azaz nem rendelkezik nukleáz aktivitással. Ennek több oka is lehet, mint pl. az, hogy nem köt meg $\mathrm{Zn}^{2+}$-iont, amiröl tudjuk, hogy elengedhetetlen a katalitikus aktivitás kifejétéséhez. Elsőként ezért a megtisztított Ub-HNH fúziós fehérje $\mathrm{Zn}^{2+}$ 
kötését vizsgáltuk meg tömegspektrometriás és $\mathrm{CD}$ spektroszkópiás eljárással. A fehérjeoldatunkat négyszeres $\mathrm{Zn}^{2+}$-felesleg jelenlétében inkubáltuk 0,1 M ammóniumacetát pufferben ( $\mathrm{pH}=8,0)$. Az ESI MS spektrum különböző töltésü ionok jellegzetes mintázatát mutatta. A tömegspektrum kiemelt részletét 5.1.6.1. ábra mutatja.

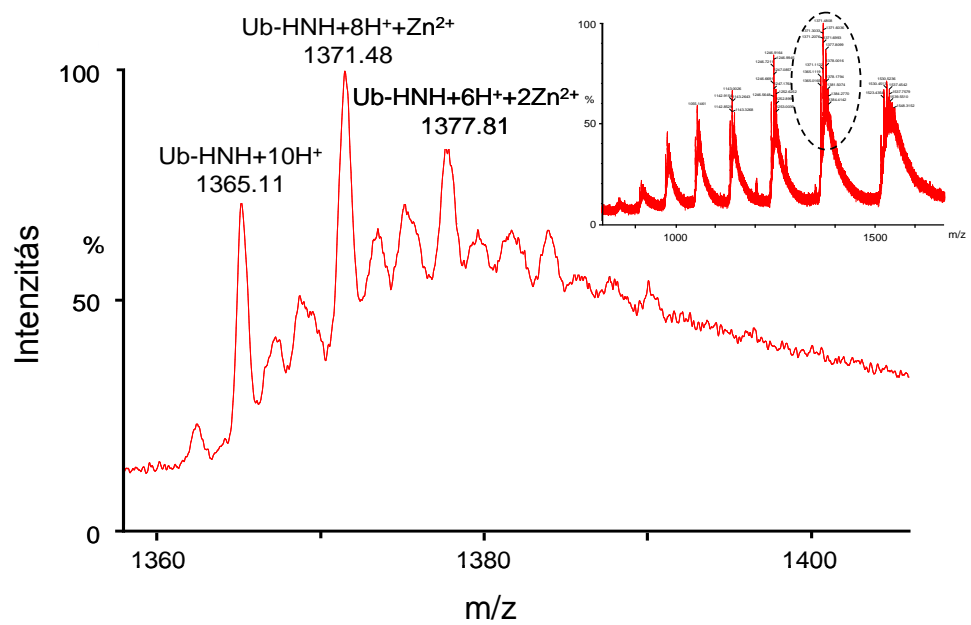

5.1.6.1. ábra: Ub-HNH fehérje tömegspektrumának részlete, négyszeres feleslegben alkalmazott $\mathrm{Zn}^{2+}$ ionok jelenlétében $0,1 \mathrm{M}$ ammónium-acetát pufferben $(\mathrm{pH}=8,0)$. Az inzert a teljes $\mathrm{m} / \mathrm{z}$ spektrumot mutatja.

A tömegspektrum (5.1.6.1. ábra) kiemelt részlete intenzív csúcsot mutat 1365,1 $\mathrm{m} / \mathrm{z}$ értéknél, ami a fémion nélküli Ub-HNH $+10 \mathrm{H}^{+}$fehérjéhez rendelhető. Emellett $1371,4 \mathrm{~m} / \mathrm{z}$ értékhez tartozó intenzív csúcs ugyanakkora töltésnél, de eltérő molekulatömegnél a fémion-tartalmú Ub-HNH $+8 \mathrm{H}^{+}+\mathrm{Zn}^{2+}$ kialakulására enged következtetni. A fenti értékekböl számított molekulatömegek 13641,1 Da, illetve 13706,8 Da, amelyek közötti különbség megfelel egy $\mathrm{Zn}^{2+}$-ion tömegének.

A hisztidin oldalláncok deprotonálódása $\mathrm{pH}$ 5,3-7,5 tartományba esik, ami egybevág a $\log k$ 6,3-6,5 értékekkel ( $k$ mikrokonstans NMR mérések alapján [91]). Tehát $\mathrm{pH}=8,0$ értéknél ezek az oldalláncok deprotonálódnak, koordinációs helyet biztosítva ezzel a $\mathrm{Zn}^{2+}$-ionnak, azaz feltételezhető, hogy a $\mathrm{Zn}^{2+}$-komplexek nem protoncserélődéssel alakulnak ki. Az Ub-HNH $+10 \mathrm{H}^{+}$pozitív töltéssel tehát nem feltétlenül az $\mathrm{Ub}-\mathrm{HNH}+8 \mathrm{H}^{+}+\mathrm{Zn}^{2+}$ komplex prekurzora. 1371,4 m/z értéknél lévő csúcshoz rendelhető komplexek a következő egyensúlyok alapján képződhetett:

$$
\mathrm{Zn}^{2+}+\mathrm{LH}_{\mathrm{x}}^{\mathrm{a}+} \rightleftharpoons \mathrm{Z} n \mathrm{~L}_{x-b}^{\left(a+H^{-b)+}\right.}+\mathrm{bH}^{+}
$$

ahol $\mathrm{a}=7-16, \mathrm{~b}=0-3$ az 5.1.6.1. táblázatban. A kérdéses $1371,4 \mathrm{~m} / \mathrm{z}$ érték a11,3; 10,2; 9,1; 8,0 a,b párokból egyaránt kiszámítható. 
5.1.6.1. táblázat: $A z$ Ub-HNH fehérjére vonatkozó számított $\mathrm{m} / \mathrm{z}$ értékek a kölünbözö protonáltsági állapotokban, fémion hiányában és jelenlétében, feltételezve, hogy a fémion három (a), kettő (b), egy (c) protont cserél le, illetve egyet sem, azaz a már deprotonálódott hisztidin oldalláncokhoz koordinálódik, nem pedig proton leszorítása útján jön létre a komplex $(\mathrm{d})$.

\begin{tabular}{|c|c|c|c|c|c|c|c|c|c|c|c|}
\hline $\begin{array}{l}\text { Protonok } \\
\text { kezdeti } \\
\text { száma }\end{array}$ & 16 & 15 & 14 & 13 & 12 & 11 & 10 & 9 & 8 & 7 & 6 \\
\hline Ub-HNH & 853,59 & 910,43 & 975,39 & 1050,35 & 1137,79 & 1241,14 & 1365,15 & 1516,72 & 1706,19 & 1949,79 & 2274,58 \\
\hline$+\mathrm{Zn}^{2+a}$ & 914,57 & 979,82 & 1055,12 & 1142,96 & 1246,77 & 1371,35 & 1523,61 & 1713,94 & 1958,64 & 2284,92 & 2741,70 \\
\hline$+\mathrm{Zn}^{2+\mathrm{b}}$ & 857,47 & 914,57 & 979,82 & 1055,12 & 1142,96 & 1246,77 & 1371,35 & 1523,61 & 1713,94 & 1958,64 & 2284,92 \\
\hline$+\mathrm{Zn}^{2+\mathrm{c}}$ & 807,09 & 857,47 & 914,57 & 979,82 & 1055,12 & 1142,96 & 1246,77 & 1371,35 & 1523,61 & 1713,94 & 1958,64 \\
\hline$+\mathrm{Zn}^{2+d}$ & 762,31 & 807,09 & 857,47 & 914,57 & 979,82 & 1055,12 & 1142,96 & 1246,77 & 1371,35 & 1523,61 & 1713,94 \\
\hline$+2 \times \mathrm{Zn}^{2+d}$ & 689,28 & 725,50 & 765,75 & 810,74 & 861,34 & 918,70 & 984,25 & 1059,88 & 1148,13 & 1252,41 & 1377,55 \\
\hline
\end{tabular}

Az ESI-MS spektrumon (5.1.6.1. ábra) olyan csúcs is látható melynek alapján az Ub-HNH fehérjéhez két $\mathrm{Zn}^{2+}$-ion is kötődik. Ennek a csúcsnak az intenzitása azonban jóval kisebb, mint a monokomplexé. Még húszszoros fémion-felesleg esetében is csak nyomokban tapasztaltuk ezen forma megjelenését. A $\mathrm{Zn}^{2+}$-ion kötésének $\mathrm{pH}$ függését $\mathrm{pH}=8,0$ és $\mathrm{pH}=3,5$ értéknél vizsgáltuk, összehasonlítva az Ub-HNH, illetve $\mathrm{Ub}-\mathrm{HNH}-\mathrm{Zn}^{2+}$ rendszerek ESI MS spektrumát. Ahogy az a 5.1.6.2. ábrán látható 3,5-ös $\mathrm{pH}-\mathrm{n}$ mind $\mathrm{Zn}^{2+}$-ionok jelenlétében, mind pedig hiányában felvettük a tömegspektrumokat +16 protonáltsági állapotig. A tömegspektrumokon csak a szabad fehérjéhez tartozó jelek azonosíthatók. Tehát az Ub-HNH fehérje nem képes megkötni a $\mathrm{Zn}^{2+}$-iont abban a $\mathrm{pH}$ tartományban, ahol hisztidin oldalláncok protonálva vannak. Azonban ha a $\mathrm{pH}=8,0$ értékre növeljük a fehérjéhez tartozó csúcs-csoportok eltolódnak az alacsonyabb töltöttségi állapotok irányába, a +10 -es protonáltsági állapotnál jelentkezik a maximum. Ezzel párhuzamosan megjelennek a $\mathrm{Zn}^{2+}$-komplexhez tartozó csúcsok is. 

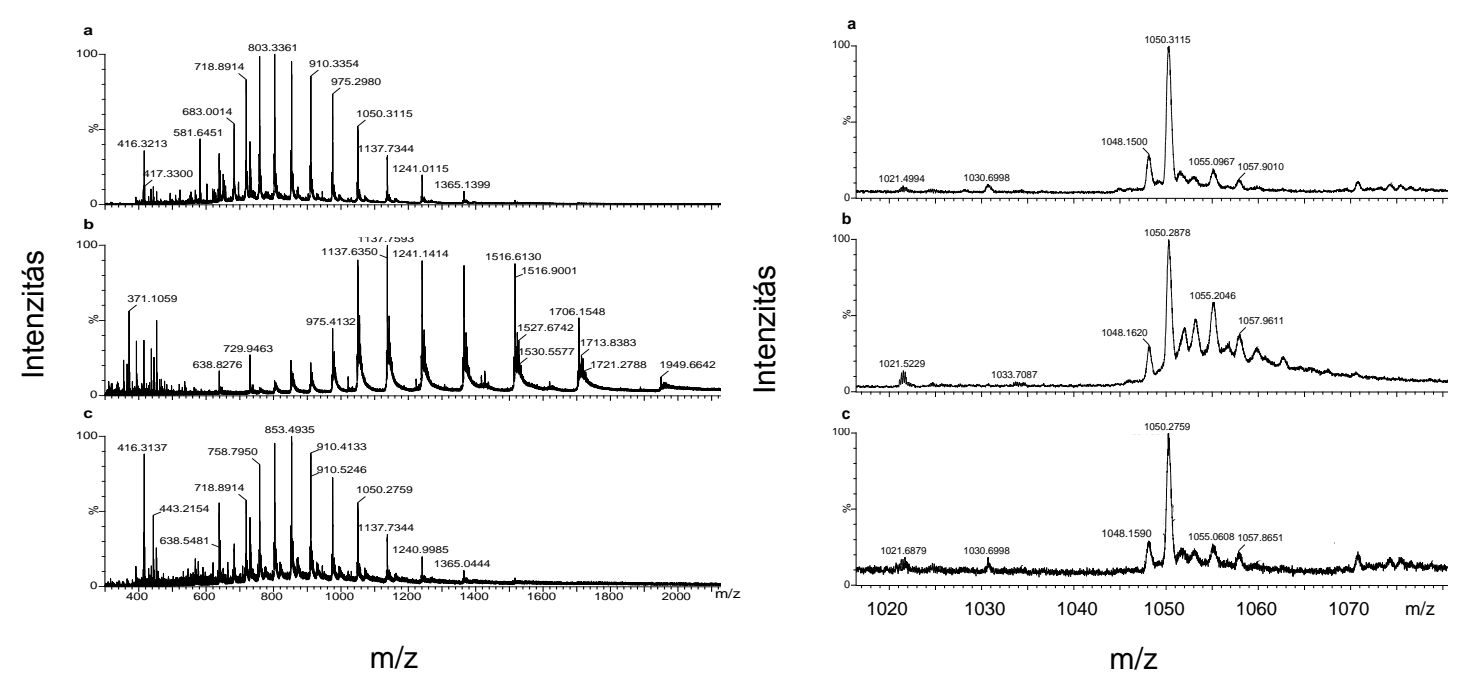

5.1.6.2. ábra: $A z$ Ub-HNH fehérje különböző $\mathrm{pH}$ értékeknél felvett ESI-MS spektrumai: fémion hiányában $\mathrm{pH}=3,5$-nél (a), két ekvivalens $\mathrm{Zn}^{2+}$-ion jelenlétében $\mathrm{pH}=8,0$ értéknél (b), két ekvivalens fémion $\mathrm{pH}=3,5$ értéknél (c). Bal oldalon a teljes spektrum látható, jobb oldalon pedig egy kinagyított részlete +13 -as töltésnél.

A fehérje $\mathrm{Zn}^{2+}$-kötését $\mathrm{CD}$ spektroszkópiás módszerrel is nyomon követtük. Az első CD mérések nem mutattak szignifikáns különbséget az Ub-HNH fehérje fémion jelenlétében és hiányában tapasztalt spektrumában $(\mathrm{pH}=7,5)$. Ezen készülék megbízhatósága azonban $200 \mathrm{~nm}$ alatt megkérdőjelezhető. Ezért ugyanezeket a méréseket SRCD berendezésen megismételtük, és kicsi, de reprodukálható eltérést tapasztaltunk fémion jelenlétében és hiányában: $\mathrm{Zn}^{2+}$-ionok hozzáadása a fehérjeoldathoz a jel intenzitásának potitív irányú eltolódását eredményezte a 190-200 nm-es tartományban (5.1.6.3. ábrán ).

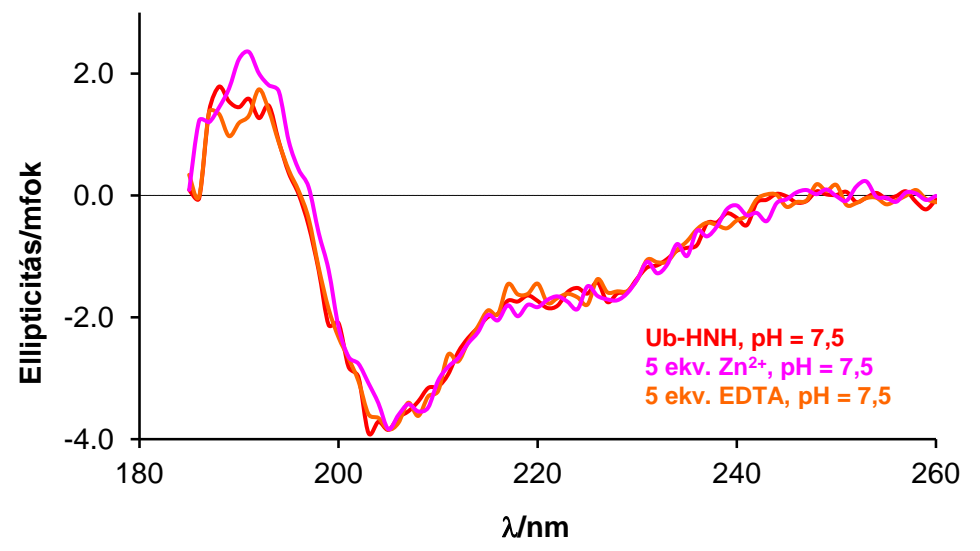

5.1.6.3. ábra: $\mathrm{Az} \mathrm{Ub}-\mathrm{HNH}$ fehérje $\mathrm{SRCD}$ spektrumai $(\mathrm{pH}=7,5) \mathrm{Zn}^{2+}$-hiányában (piros), ötszörös fémion felesleg jelenlétében (ciklámen), illetve EDTA feleslegben történő hozzáadására (narancssárga). 
Hasonló változást tapasztaltak az irodalomban a ColE9 nukleáz domén esetében $\mathrm{Zn}^{2+}$-ion megkötödésekor [58], ami utalhat a $\mathrm{Zn}^{2+}$-ion hatására történő kismértékü másodlagos szerkezeti változásokra a NHN motívumban. A $\mathrm{Zn}^{2+}$-ion hatására bekövetkező változás visszafordítható EDTA hozzáadásával, aminek következtében a fémionmentes Ub-HNH spektrumát kaptuk vissza.

\subsubsection{A HNH motívum előállítása ubikvitin-HNH (Ub-HNH) fúziós fehérjéből}

Hogy meggyőzödhessünk arról, hogy a fentiekben mért változások valóban a $\mathrm{HNH}$ motívum és a $\mathrm{Zn}^{2+}$-ion kölcsönhatásának következménye, a $\mathrm{HNH}$ motívum tulajdonságainak további vizsgálata céljából előállítottuk a fehérjét fúziós fehérje jelenléte nélkül is. Mint azt már az 5.1.4. fejezetben láttuk egy specifikus proteáz hasítással ugyan az ubikvitin fehérje lehasítható, de ez a folyamat a sejten belül a HNH fehérje lebontásához vezetett. Erre a problémára megoldást jelentene, ha in vitro hasítást végezhetnénk. Ehhez azonban a tisztított Ub-HNH fehérjének és tisztított specifikus proteáznak is rendelkezésünkre kell állnia. Ennek érdekében döntöttünk úgy, hogy mindkét fehérjét egy olyan toldalékkal állítjuk elő, mely affinitás kromatográfiával történő tisztítást tesz lehetővé. (A fentiekben részletezett in vivo hasítás utáni sikertelen detektálás után a HNH fehérje tisztítását két lépésben lehetett volna megvalósítani, egy ioncserés és egy gélszüréses módszerrel. Ebben az esetben magának a fúziós fehérjének a tisztítása két lépés, majd a proteáz hasítás után mind a proteáztól, mind az ubikvitintől meg kell szabadulnunk, hogy tiszta HNH-t kapjunk. Azaz minimum háromlépéses a tisztítás, amely minden egyes lépése optimalizálást igényel.)

Ezért az Ub-HNH génjét új plazmidba ültettük át: a pHUE vektorban (F.6. ábra) jelenlévő hexahisztidin toldalék az Ub-HNH N-terminális részére került további fúziós részként. A hasítás után His-Ub rész a $\mathrm{Ni}^{2+}$-ionokat, mint kötőhelyeket tartalmazó affinitás-oszlopon kötődve marad, míg a HNH szabadon lemosható. Az elválasztás során pHUE/pHUsp2-cc rendszer előnye még, hogy a hasítást végző specifikus proteáz (Sp2-cc) is rendelkezik His fúziós résszel (His-pHUsp2), így szintén felkötődik az oszlopra. A tisztítást lényegesen megkönnyíti ezen Ni-affinitás kromatográfiás lépés bevezetése [62].

Az új HUE-HNH fúziós fehérjét E. coli sejtekben fejeztük ki. Az első Niaffinitás tisztítás után HUE-HNH fehérjét választottuk el a baktérium többi fehérjéjétől majd a pHUsp2-cc enzimmel emésztettük. A HNH részt elválasztottuk a lehasított 
fúziós résztől illetve a proteáztól (5.1.7.1.ábra). Ezzel az eljárással végül 2,5 mg tiszta HNH fehérjét kaptunk 1 liter baktérium-tenyészetből.

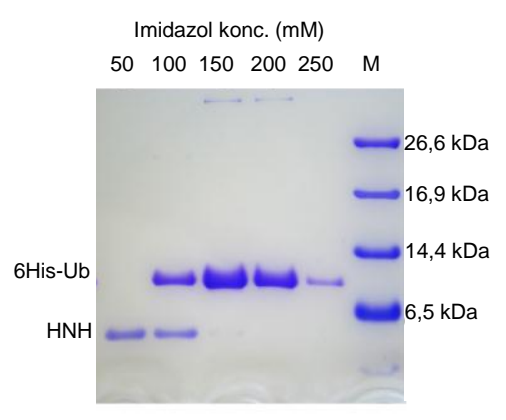

5.1.7.1. ábra: SDS-PAGE gélkép a HNH fehérje tisztításának eredményéröl a fúziós részek eltávolítása után. Az első oszlop a hasítás utáni elúciós frakció, amely a HNH motívumot tisztán tartalmazza. Mivel a HNH motívumban jelenlévő négy hisztidin képes gyenge kölcsönhatás kialakítására az oszlopon kötött $\mathrm{Ni}^{2+}$-ionokkal, már itt is szükség volt kis koncentrációjú $(50 \mathrm{mM})$ imidazol alkalmazásra az elúciós folyamatban. Nagyobb imidazol koncentrációjú (100-250 mM) eluens hatására már a hexahisztidin résszel kötődő HUE fúziós rész is detektálható, illetve magasabb molekulatömegnél az alkalmazott proteáz látható.

\subsubsection{A HNH motívum $\mathrm{Zn}^{2+}$-kötésének vizsgálata}

A $\mathrm{HNH}$ motívum $\mathrm{Zn}^{2+}$-kötését tömegspektrometriás módszerrel követtük nyomon (ESI-MS, MALDI-MS). $\mathrm{pH}=3,5$ és $\mathrm{pH}=8,0$ kémhatású oldatok mérését végeztük el. A magasabb $\mathrm{pH}-\mathrm{n}$ a $\mathrm{Zn}^{2+}$-iont kötésben tartó fehérje aránya jelentősen nőtt, de mindkét esetben mind az apo-, mind a holofehérje detektálható volt (5.1.8.1.ábra).
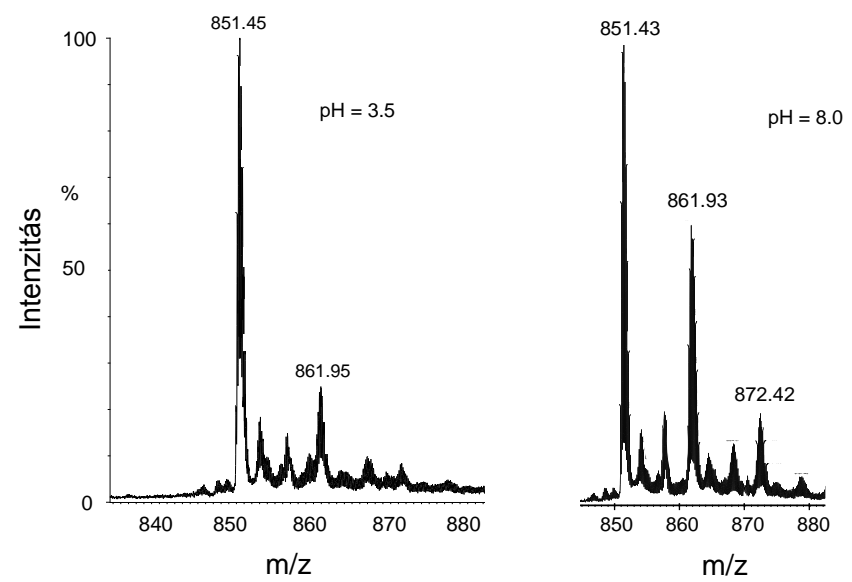

5.1.8.1. ábra: $\mathrm{A} H \mathrm{HNH}$ fehérje ESI-MS spektruma négyszeres $\mathrm{Zn}^{2+}$-felesleg jelenlétében $\mathrm{pH}=3,5$ (bal oldal) és $\mathrm{pH}=8,0$ (jobb oldal) körülmények között. 
A MALDI MS spektrumban húszszoros fémionfelesleg jelenlétében is a tömegspektrum fő csúcsa a szabad HNH-hoz rendelhető. Emellett egyetlen további csúcs volt detektálható, mely a HNH-Zn-fehérje komplexnek felelt meg (nincs az ábrán bemutatva). Az SRCD mérések szerint $\mathrm{Zn}^{2+}$-ion távollétében nincs szignifikáns különbség a fehérje szerkezetében $\mathrm{pH}=3,0$, illetve $\mathrm{pH}=7,5$ kémhatású oldatokban (5.1.8.2. ábra). Ugyancsak nem tapasztaltunk változást $\mathrm{pH}=3,5$-nél a $\mathrm{Zn}^{2+}$-ion hozzáadása következtében. Viszont a $\mathrm{HNH}$ fehérje $\mathrm{pH}=7,5$ kémhatású oldatához két ekvivalens $\mathrm{Zn}^{2+}$-iont adva, kismértékű változás figyelhető meg a $\mathrm{CD}$ spektrumban $\mathrm{pH}=$ 7,5-nél, ami arra utal, hogy ilyen körülmények között változás történt a fehérje másodlagos szerkezetében a fémion hatására (5.1.8.2. ábra).

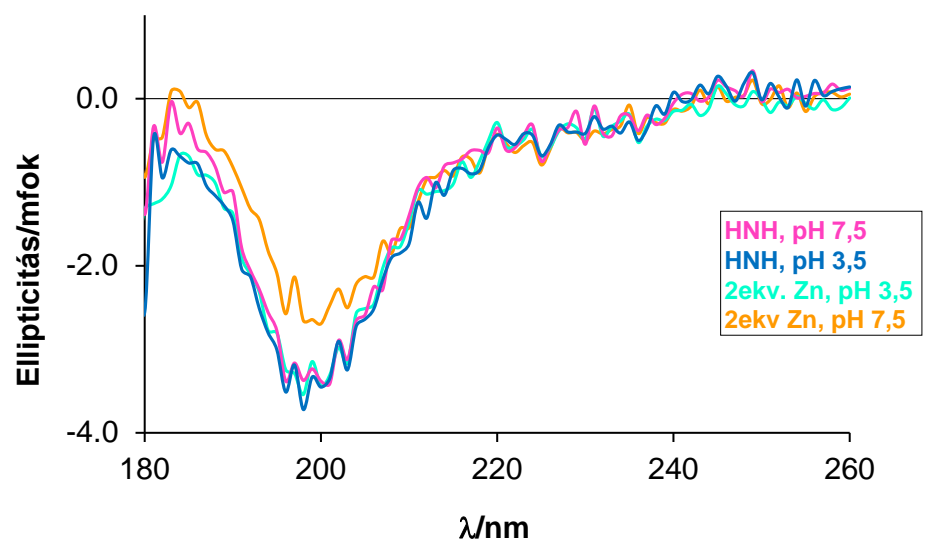

5.1.8.2. ábra: A HNH motívum $S R C D$ spektrumai. A $p H$ hatása $(\mathrm{pH}=3,5$ ill. $\mathrm{pH}=7,5)$ a peptid konformációjára $\mathrm{Zn}^{2+}$-ion jelenlétében és hiányában.

Ez jó visszaigazolása annak, hogy az Ub-HNH esetében tapasztalt változások valóban a HNH részlet szerkezeti változásából erednek, azaz az ubikvitin fúziós rész zavaró hatása elhanyagolható. A CDPro programcsomag [92] segítségével végzett számítások szerint a nagyobb mértékben rendezett szerkezeti elemek, mint az $\alpha$-hélix, illetve a $\beta$-redő arányainak növekedése tapasztalható a fémion koordiánciójakor vizes oldatban 20\% TFE (trifluoro-etanol) jelenlétében (5.1.8.1. táblázat). Ugyanakkor $80 \%$ TFE jelenlétében, ahol a HNH fehérje főként $\alpha$-helikális szerkezetet vesz fel, fémion hozzáadására e másodlagos szerkezeti elem arányának csökkenése tapasztalható a $\beta$ redők javára. Ezek alapján valószínüsíthető, hogy függetlenül az oldószertől, fémion hozzáadására a kristályszerkezethez közelítő oldatszerkezet kialakulása a kedvezményezett $[53,55,75,78]$. 
5.1.8.1. táblázat: A CDPro programcsomag segítségével [92] másodlagos szerkezeti elemek számított aránya százalékban kifejezve.

\begin{tabular}{|l|c|c|c|c|c|c|}
\hline & \multicolumn{2}{|c|}{ puffer } & \multicolumn{2}{c|}{$20 \%$ TFE } & \multicolumn{2}{c|}{$80 \%$ TFE } \\
\hline & HNH & $\begin{array}{c}\text { Zn- } \\
\text { HNH }\end{array}$ & HNH & $\begin{array}{c}\text { Zn- } \\
\text { HNH }\end{array}$ & HNH & $\begin{array}{c}\text { Zn- } \\
\text { HNH }\end{array}$ \\
\hline $\boldsymbol{\alpha}$-hélix & 6.0 & 7.0 & 16.0 & 21.0 & 40.0 & 34.0 \\
\hline $\boldsymbol{\beta}$-redő & 16.0 & 28.0 & 20.0 & 23.0 & 11.0 & 17.0 \\
\hline kanyar & 23.0 & 24.0 & 23.0 & 22.0 & 22.0 & 20.0 \\
\hline egyéb & 55.0 & 41.0 & 41.0 & 34.0 & 27.0 & 29.0 \\
\hline
\end{tabular}

Fluoreszcencia spektroszkópiás méréseket is végeztünk, hogy kiderítsük vajon a $\mathrm{HNH}$ fehérje képes-e versenyezni a TFLZn fluoreszcens festékkel a $\mathrm{Zn}^{2+}$-ion megkötésében. Amennyiben a Zn(TFLZn $)_{2}$ komplexből a HNH képes elvonni a fémiont, annak fluoreszcencia intenzitása csökken. A Zn:TFLZn:HNH 1:2:2 arányú rendszerben a fehérje jelenléte kismértékü floureszcencia csökkenést eredményezett.

\section{(5.1.8.3. ábra)}

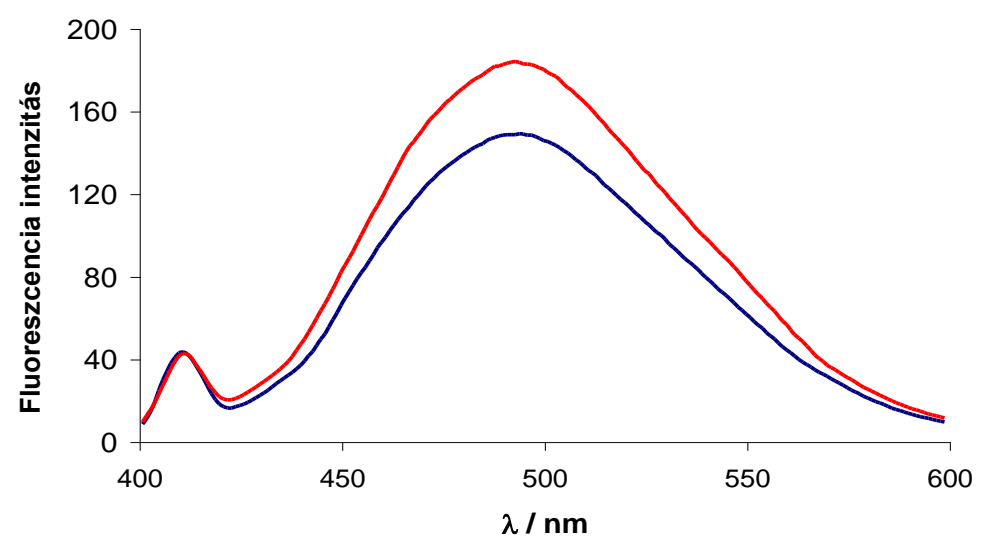

5.1.8.3. ábra: $A H N H$ motívum hatása a Zn-TFLZn rendszer fluoreszcencia spektrumára. A TFLZn oldatához fél ekvivalens $\mathrm{Zn}^{2+}$-iont adtunk egy ekvivalens $\mathrm{HNH}$ fehérje jelenlétében (kék), illetve hiányában (piros). 


\subsubsection{A HNH motívum DNS kötése és nukleáz aktivitása}

A pHUE-HNH plazmidból kifejezett és megtisztított $\mathrm{HNH}$ fehérjét $\mathrm{Zn}^{2+}$-ion jelenlétében és hiányában DNS-sel inkubálva különböző körülményeket alkalmazva, nem tapasztaltunk DNS kötést, ill. nukleáz aktivitást (5.1.9.1. ábra).

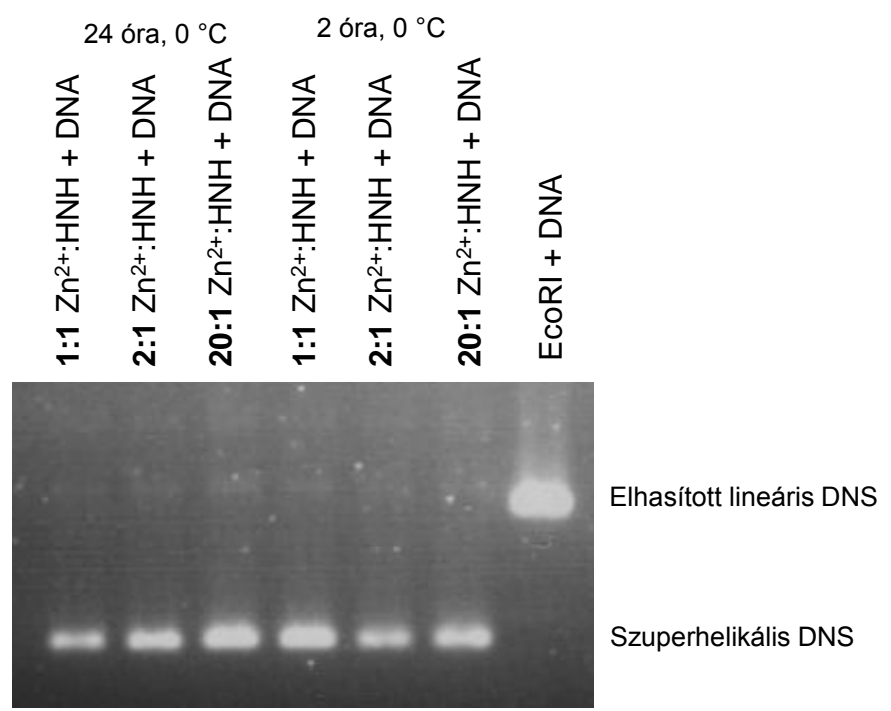

5.1.9.1. ábra: A $\mathrm{HNH}$ motívum $(0,05 \mathrm{M}$ Tris- $\mathrm{HCl}, \mathrm{pH}=7,5)$ DNS kötésének és nukleáz aktivitásának vizsgálata különböző körülmények között agaróz gélelektroforézis segítségével. Szubsztrátként pUC18 szuperhelikális DNS-t használtunk, melynek sávja az ábrán látható szuperhelikális DNS-sel megegyező helyen volt detektálható. 


\subsubsection{Az eredmények tárgyalása}

A colicin E7 aktív központját alkotó HNH motívumtól azt vártuk, hogy mint az evolúció során jól megőrzött szerkezeti egység nemspecifikus nukleázként müködhet. Így specifikus DNS szekvenciát felismerő fehérjékkel összefüzve, a későbbiekben egy újfajta mesterséges metallonukleáz alapját képezheti. Egy ilyen fehérje kifejezése potenciális citotoxikus hatás miatt gondos körültekintést igényel. Kísérleteink során végül nem a nukleáz aktivitás, hanem a 42 aminosavas $\mathrm{HNH}$ motívum kis mérete miatt adódtak nehézségeink. Ezeket leküzdve kerülő úton jutottunk el a fehérje fúziós fehérjeként történő kifejezéséig (5.1.5.1. ábra). Az, hogy az Ub-HNH fehérjét nagy mennyiségben sikerült kifejeznünk egyben azt is jelenti, hogy e fehérjének nincs nukleáz aktivitása. Az aktivitás hiányának egyik valószínűsíthető oka a fémion-kötés hiánya volt, ezért elsőként a fehérje- $\mathrm{Zn}^{2+}$-ion kölcsönhatást vizsgáltuk meg ESI-MS, CD és fluorimetriás módszerekkel.

Irodalmi adatok alapján a colicin E7 fehérjével nagy szekvenciaazonosságot mutató colicin E9 fehérje nukleáz doménjének ESI-MS spektrumán kettős töltöttségi állapot jelenléte figyelhető meg [58], azaz két különböző konformációban létezhet a fehérje. A fémion hozzáadása kompaktabb konformációba történő átalakulást indukált. Ezzel ellentétben az Ub-HNH fehérjénél nem tapasztaltunk hasonló jelenséget, ami arra utal, hogy az ubikvitin fúziós rész nincs kölcsönhatásban a $\mathrm{HNH}$ résszel sem $\mathrm{Zn}^{2+}$-ion jelenlétében, sem pedig hiányában. Ezt támasztják alá az 5.1.6.1. ábrán, illetve az 5.1.6.2. ábrán látható ESI-MS tömegspektrumok. Az irodalomban olvashatunk [57] olyan szerkezetre vonatkozó feltevést, miszerint a colicin nukleázok katalitikus doménje $\mathrm{N}$-terminális részének szerepe lehet a fémion megkötésben. Az ubikvitin fúziós rész nem tölt be szerepet a fúziós fehérjében. Mivel az ubikvitin jól definiált szerkezete intenzív CD jelet eredményez eltávolítása a HNH fehérje szerkezetének megváltozását $\mathrm{Zn}^{2+}$-ion hozzáadására követhetővé teszi $\mathrm{CD}$ spektroszkópiás módszerrel. Az 5.1.8.2. ábrán hasonló pozitív irányú változások tapasztalhatók, mint az Ub-HNH fehérje esetében az 5.1.6.3. ábrán, de a relatív változás jóval nagyobb mértékü a spektrumban. Ezeket szerkezeti változásokat a 5.1.8.1. táblázatban foglaltuk össze, ami alapján elmondhatjuk, hogy a kristályszerkezet alapján várt szerkezet részben kialakul vizes oldatban is. $[53,55,75,78]$.

$\mathrm{Az}$ 5.1.6.1. ábrán látható tömegspektrumok nyomnyi mennyiségü kétmagvú $\mathrm{Zn}^{2+}$-komplex jelenlétét is igazolták, egy második, gyengébb fémkötő-helynek 
megfelelően a HNH motívumban. Ez összevethető azzal az irodalmi adattal, mely szerint $\mathrm{Zn}^{2+}$-felesleg jelenlétében megszünik a ColE7 fehérje nukleáz aktivitása. Ennek ugyanis valószínűleg az az oka, hogy a HNH motívumban lévő negyedik hisztidinhez koordinálódó második fémion megakadályozza, hogy az általános bázisként betöltse szerepét a katalízisben. [72]

A fluoreszcencia spektroszkópiás mérések (5.1.8.3. ábra) alapján megállapítottuk, hogy a HNH motívum a fémion belső koordinációs szféráját nem tölti be, a negyedik koordinációs hely szabadon marad, ahová például egy vízmolekula vagy a szubsztrát kötődhet be.

A fentiek alapján sem az Ub-HNH sem pedig a $\mathrm{HNH}$ motívum nem mutat az irodalomban olvasott [75] nagy affinitást a $\mathrm{Zn}^{2+}$-ion megkötése során. Ennek oka a HNH fehérje szerkezeti felépítésében keresendő. Mind a DNS-kötést illető, mind pedig a nukleáz aktivitásra (5.1.9.1. ábra) vonatkozó negatív eredmények mégis nehezen magyarázhatóak pusztán a $\mathrm{Zn}^{2+}$-ion gyenge kötődésével. Ugyanis még akkor is van $\mathrm{Zn}^{2+}$-HNH komplex az oldatban, ha feltételezhetően annak kialakulása nem 100\%-os. Eszerint a katalitikus aktivitás hiánya nagy valószínüséggel a DNS-kötő rész hiányának tudható be. 


\subsection{Különböző NColE7 mutánsok előállítása és vizsgálata}

A C-terminális HNH motívum önmagában nem mutatott nukleáz aktivitást, ezért az N-terminális vég felé haladva több lépésben építettük vissza a ColE7 nukleáz domént azzal a céllal, hogy megtaláljuk a nukleáz aktivitásért felelős minimális méretü fehérjerészletet. A HNH motívum, a már meglévő NColE7 szerkezet alapján mindig egy-egy nagyobb szerkezeti egységgel bővült a különböző mutánsokban. Az 5.2.1. ábrán az elöállított mutánsok szekvenciája és kristályszerkezetek alapján feltételezett szerkezete látható. A szerkezet az egyes részletek hiányában természetesen a valóságban más lehet, így az ábra csak a nagyobb szerkezeti egységek visszaépítésének szemléltetését szolgálja.

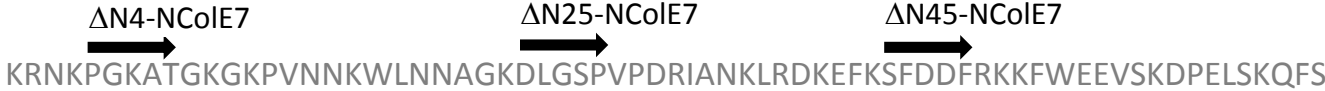

\section{RNNNDRMKVGKAPKTRTQDVSGKRTSFEL $\underline{H}$ HEKPISQNGGVYDMDNISVVTPKRㅂIIDIㅌRGK \\ $\triangle$ N69-NColE7}

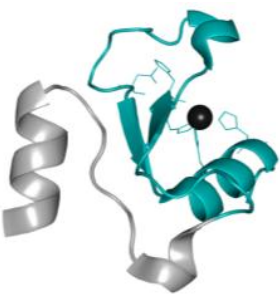

$\triangle$ N69-NColE7

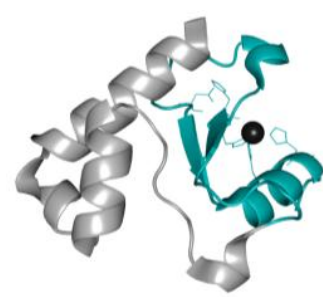

$\triangle N 45-N C O I E 7$

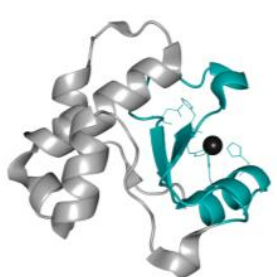

$\triangle N 25-N C O l E 7$

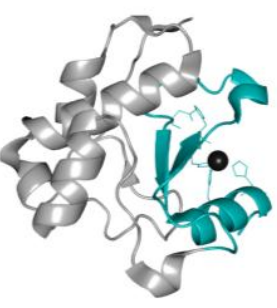

$\triangle \mathrm{N} 4-\mathrm{NCOlE7}$

5.2.1. ábra: A különböző NColE7 mutánsok aminosav szekvenciája és a hozzájuk tartozó feltételezett szerkezet.

5.2.1. táblázat: $\mathrm{Az} \mathrm{N}$-terminális $\mathrm{NColE7}$ mutánsok génjeinek előállitásához felhasznált primerek. Aláhúzva az EcoRI (GAATTC), XhoI (CTCGAG) restrikciós endonukleázok felismerési helyeit ábrázoltuk. (Az NColE7 fehérje DNS szekvenciája az F.7. ábrán látható.)

\begin{tabular}{|c|c|}
\hline Név & Szekvencia $\left(5^{\prime} \rightarrow 3^{\prime}\right)$ \\
\hline$\Delta$ N69-NColE7 & GCGAATTCAGGAACAATAATGATCGAATGAAGG \\
\hline$\Delta \mathrm{N} 45-\mathrm{NCO} E 7$ & GCGAATTCAGTTTCGATGATTTTTCGTAAGAAATTC \\
\hline$\Delta \mathrm{N} 25-\mathrm{NCO} E 7$ & GGAATTCGACTTAGGTTCTCCTGTTCCA \\
\hline$\Delta \mathrm{N} 4-\mathrm{NCOIE7}$ & GGAATTCCCAGGGAAGGCAACAGGTA \\
\hline ColE7 inverz & GCCGCTCGAGCTATTTACCTCGGTGAATATCAATATGC \\
\hline
\end{tabular}


A mutáns fehérjék génjeit polimeráz láncreakcióval állítottuk elö az általunk tervezett primerekkel (5.2.1. táblázat), majd az előállított génszakszokat pGEX-6P-1 vektorba ligáltuk. A vektor tartalmazza a glutation-S-transzferáz (GST) fehérje génjét, amely a későbbi elválasztás megkönnyítését szolgálja. Ezen fehérje C-terminális végéhez hozzáfüzve a mutáns fehérjéket, GST-fúziós fehérjék állíthatók elő. A mutáns fehérjék génjét tartalmazó plazmidokat klónozás céljából E. coli (DH10B vagy Mach1) baktériumsejtekbe jutattuk. DNS szekvenálás segítségével (Japánban, témavezetőm által elvégzett kísérletek során) ellenőriztük az N-terminális részen végrehajtott módosításokat. A pozitív szekvenálási eredmények után megkezdtük e mutáns fehérjék BL21(DE3) E. coli baktériumokban történő kifejezését. Amennyiben a képződő fehérje rendelkezik az NColE7 által is képviselt nukleáz aktivitással, a fehérjekifejezés indukálása (IPTG) után a baktériumok elpusztulnak, a tápoldat optikai sürüsége $\left(\mathrm{OD}_{600}\right)$ csökken. A nukleáz aktivitással rendelkező fehérje toxikus hatása, a baktériumsejtek számának, azaz $\mathrm{OD}_{600}$ csökkenését okozza. Mint az az 5.2.2. ábrán látható, nukleáz aktivitást nem tapasztaltunk mindaddig, amíg a teljes nukleáz domént vissza nem építettük, tehát még a $\Delta \mathrm{N} 4-\mathrm{NC}$ ColE7 mutánsból elhagyott négy $\mathrm{N}$-terminális aminosav jelenléte is szükséges az enzim működéséhez.

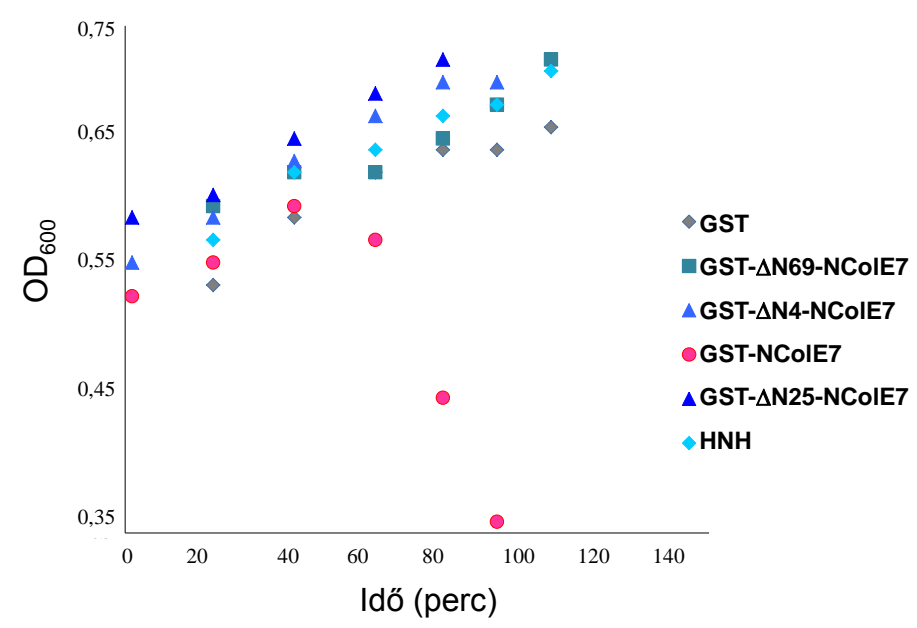

5.2.2. ábra: A GST-fúziós fehérjeként előállított NColE7 mutánsok toxicitásának vizsgálata az $\mathrm{OD}_{600}$ változásán keresztül a fehérjekifejezés indukálása után. A GST fehérjét önmagában, negatív (nem toxikus) összehasonlító kísérletben használtuk fel. Látható, hogy a GST- $\mathrm{N} 25-\mathrm{NColE7}$, GST- $\Delta$ N4NColE7 mutáns ezen, nem toxikus fehérjéhez hasonlóan viselkedik, míg a toxikus GST-NColE7 fehérje kifejeződése esetén drasztikusan lecsökkent a baktériumok száma. 
A fenti eredmények fényében megállapíthatjuk, hogy az N-terminális aminosavak jelenléte elengedhetetlenül szükséges a nukleáz aktivitás meglétéhez, még abban az esetben is, ha a fehérje már a sejten belül található [82]. Ez a megállapítás egy olyan jövőbeli mesterséges metallonukleáz fejlesztésére nyújt lehetőséget, amely pozitív allosztérikus szabályozás mellett képes müködni, tehát ha a fehérje sejten belüli degradáció révén bármilyen sérülést szenved, elveszíti aktivitását. Amennyiben a C-, és az N-terminális rész megfelelő térbeli elrendeződése biztosítja az aktivitást, a közbülső rész mutációjával vagy cseréjével specifikus DNS szekvencia felismerése válna lehetségessé. Egy ilyen enzim megtervezéséhez első lépésként az N-terminális aminosavak szerepét kell tisztáznunk: az N-terminális aminosavak hiányában van-e és ha van milyen mértékü a szerkezet változása? A DNS kötés erőssége hogyan változik az N-terminális mutációk hatására? A katalitikus hatás kifejtéséhez elengedhetetlenül szükséges fémion megkötését a C-terminális aktív központban befolyásolja-e az Nterminális végen végrehajtott változtatás? E kérdések megválaszolására a továbbiakban a $\Delta$ N25-NColE7, $\Delta$ N4-NColE7 mutáns fehérjék előállításának és tisztításának optimalizálására és tulajdonságaik vizsgálatára összpontosítottunk.

\subsubsection{A $\Delta$ N25-NColE7 és $\Delta$ N4-NColE7 fehérjék előállítása és tisztítása}

A mutánsok génjét tartalmazó pGEX-6P-1 plazmidot fehérje termelésre alkalmas BL21(DE3) E. coli törzsbe jutattuk, majd indukálószer hozzáadásával fejeztük ki a fehérjéket, melyek jelenlétét SDS-PAGE segítségével ellenőriztük. A fehérjekifejezést mindkét fehérje esetében optimalizáltuk, hogy ki tudjuk választani a legjobb kitermelést nyújtó körülményt. Az 5.2.1.1. ábrán a GST- $\Delta N 25-N C o l E 7$ mutáns kifejezésének optimalizálásával kapcsolatos SDS-PAGE képet mutatjuk be.

Látható, hogy a $30{ }^{\circ} \mathrm{C}$-on, 16 órán át tartó fehérjekifejezés során az összes mutáns fehérje kicsapódik (az oldhatatlan fázisban detektálható), ami jelentősen nehezíti a tisztítását. Ezen eredmények alapján az első körülményt találtuk megfelelőnek, így a továbbiakban 3 órán keresztül $30^{\circ} \mathrm{C}$-on történt a fehérjekifejezés. 


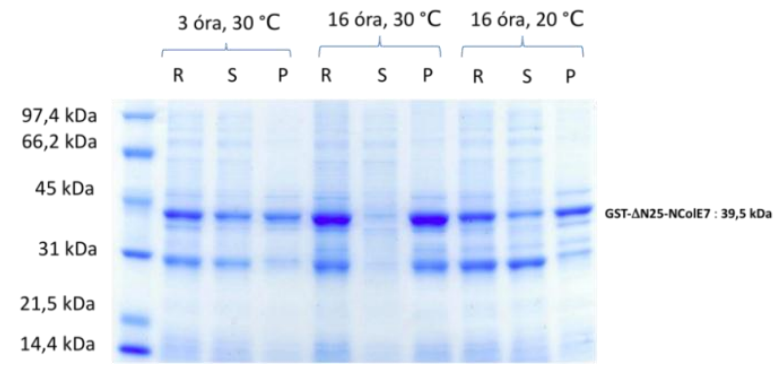

5.2.1.1. ábra: A GST- $\triangle \mathrm{N} 25-\mathrm{NC}$ ColE7 mutáns fehérje kifejezésének optimalizálására vonatkozó SDSPAGE kép $E$. coli sejtekben különböző hőmérsékletek, időtartamok alkalmazásával, de ugyanazon IPTG koncentráció jelenlétében $50 \mathrm{ml}$ LB tápoldatban. $\mathbf{R}$ betú jelöli minden esetben az ultrahangos roncsolást követően kapott szuszpenziót. $\mathbf{S}$ betűvel a centrifugálás után kapott felülúszó frakciót, azaz az oldható fázisban maradt fehérjéket jelöltük, amelyből a célfehérje megtisztítható. $\mathbf{P}$ betű jelöli a centrifugálás után kapott sejttörmeléket, amelyben az oldhatatlan fehérjék találhatóak.

A megfelelő fehérjekifejezési körülmény alkalmazásával elöállított nagyobb mennyiségü oldható fázisban maradt célfehérjék megtisztítása, azaz elválasztása a baktérium saját fehérjéitől nem egyszerű feladat. Több lépéses kromatográfiás elválasztást igényel, melyeket szintén optimalizálni kellett. Esetünkben a második lépésben alkalmazott ioncserés elválasztás megfelelő körülményeinek megtalálása ütközött nehézségekbe. A baktériumsejtekből a kísérleti részben leírtak alapján kinyertük az oldható fehérjéket. A tisztítási folyamat első lépése GST-affinitás kromatográfia volt (5.2.1.2. ábra, 5.2.1.3. ábra).

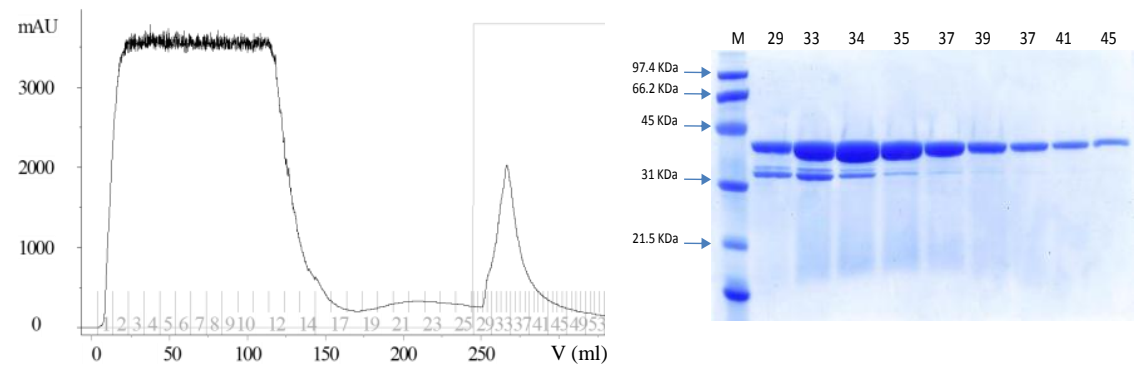

5.2.1.2. ábra: A GST- $\Delta N 25-N C o l E 7$ fehérje $\left(M_{r}=39,5 \mathrm{kDa}\right)$ tisztítása GST-affinitás kromatográfiával. Bal oldalon a kromatogram, jobb oldalon pedig a frakciók fehérjetartalmának ellenörzésére végrehajtott SDS-PAGE képe látható. Az utóbbin az oszlopok számozása megegyezik a kromatogram X tengelye felett feltüntetett frakciók sorszámával. A 280 nm-en detektált kromatogram 1-17 frakciója a baktérium összes olyan fehérjéjét tartalmazza, melyek GST-fúziós rész hiányában nem képesek megkötődni az oszlopon. A számunkra fontos GST- $\Delta \mathrm{N} 25-\mathrm{NColE7}$ fehérje az elúció során gyűjtött 28-46 frakciókban található. A redukált glutation megjelenését az eluensben szürke függőleges vonal jelzi a kromatogramon. 


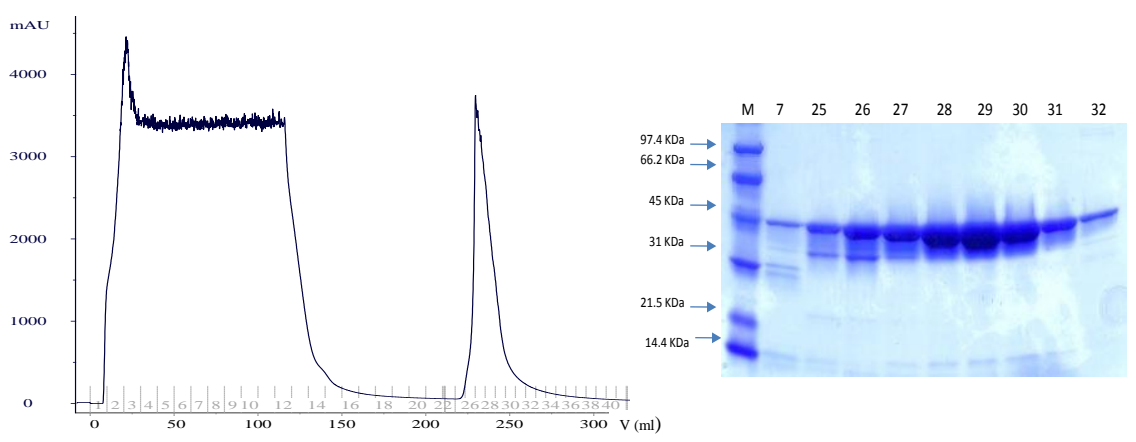

5.2.1.3. ábra: $A$ GST- $\triangle N 4-N C o l E 7$ fehérje GST-affinitás oszlopon végrehajtott tisztításának eredménye. A kromatogram 1-16 frakciói az átfolyó fehérjéket, 26-36 frakciók az eluált GST- $\Delta$ N4-NColE7 fehérjét $\left(\mathrm{M}_{\mathrm{r}}=40,5 \mathrm{kDa}\right)$ tartalmazzák. A bal és a jobb oldali képek azonosítása megegyezik az előző ábránál leírtakkal.

Az SDS-PAGE képeken jó látszik, hogy már az első lépésben a szennyező fehérjék többségét sikerült eltávolítanunk. Az így megtisztított GST- $\Delta$ N25-NColE7, GST- $\triangle$ N4-NColE7 fehérjékről egy specifikus (GST-3C) proteáz hasítással a GST rész eltávolítható. A proteázt már ismert eljárás szerint állítottuk elő és szintén GST oszlopon tisztítottuk. (5.2.1.4. ábra)

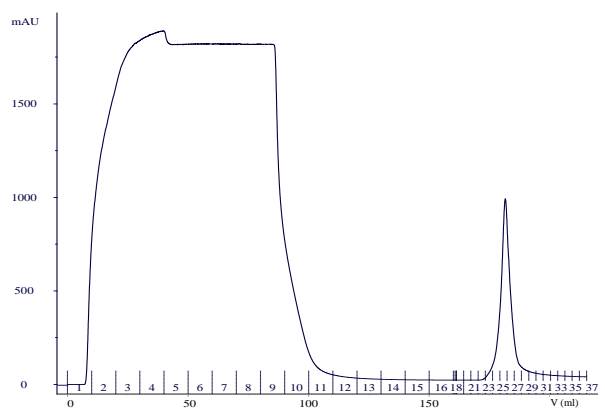

5.2.1.4. ábra: GST-3C proteáz tisztításának kromatogramja. Az 1-11 átfolyó frakció a baktérium egyéb fehérjéjéit tartalmazza, az eluált 23-29 frakciókat összeöntöttük. Ebből az enzimet NColE7 mutáns fehérje, a fehérje:proteáz 7:1 moláris arányban adtuk a GST fúziós fehérjékhez.

Fúziós fehérjéinket a GST lehasítása után, szintén GST affinitás oszlop segítségével különítettük el a lehasított GST fehérjétől, valamint magától a GSTproteáztól. A célfehérjéket ez esetben az átfolyó frakcióban gyüjtöttük. Az így kapott $\triangle \mathrm{N} 4-\mathrm{NColE7}$ (5.2.1.5. ábra) és $\triangle \mathrm{N} 25-\mathrm{NColE7}$ (5.2.1.6. ábra) fehérjék további tisztítást igényeltek, ezért a következő lépésben kationcserélő oszlopon tisztítottuk, majd SDS-PAGE segítségével ellenőriztük a különböző frakciók tisztaságát. 


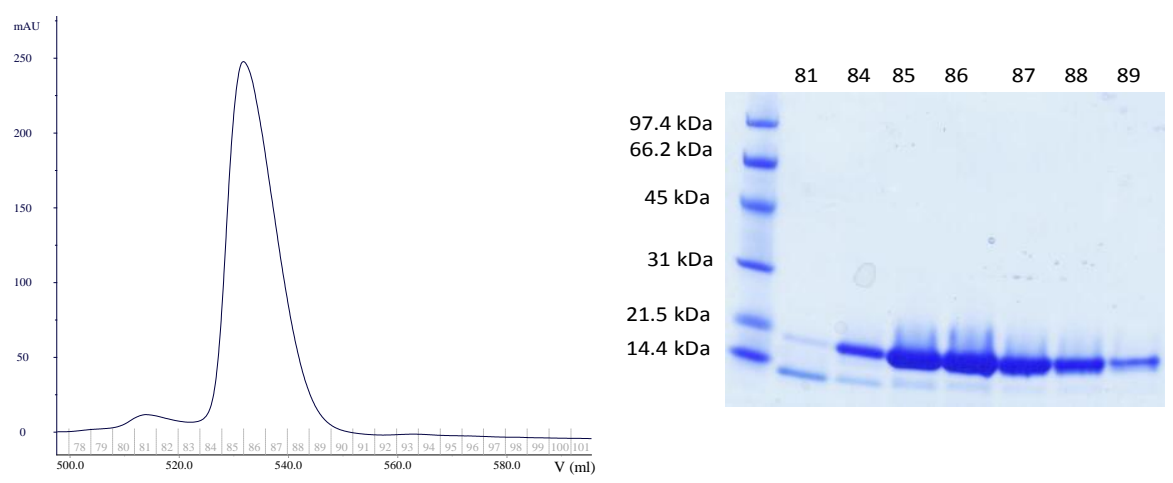

5.2.1.5. ábra: $\triangle \mathrm{N} 4-\mathrm{NColE} 7$ fehérje tisztítása ioncsere kromatográfiával: a kromatogram célfehérje elúcióját mutató részlete és a megfelelő frakciókhoz tartozó SDS-poliakrilamid gél képe. A 81-es frakcióhoz tartozó kisebb csúcs a célfehérjénél kisebb méretű, valószínűleg részben lebomlott fehérje. 8589 frakciók a megtisztított $\Delta \mathrm{N} 4-\mathrm{NC}$ ColE7 fehérjét $\left(\mathrm{M}_{\mathrm{r}}=15,4 \mathrm{kDa}\right)$ tartalmazzák.

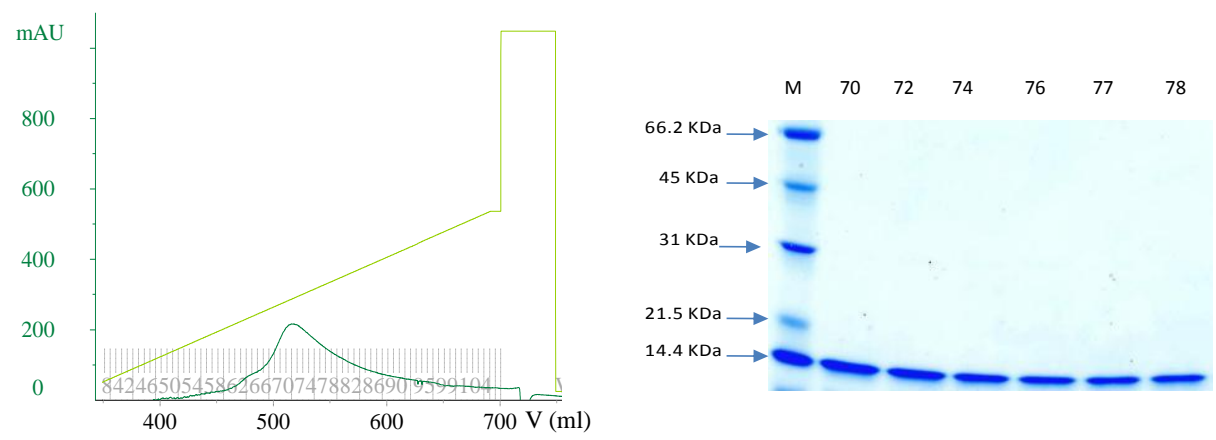

5.2.1.6. ábra: $\triangle N 25-N C o l E 7$ fehérje $\left(M_{r}=13,9 \mathrm{kDa}\right)$ ioncsere kromatogramján látható, hogy a fehérjét gradiens elúciót alkalmazva választottuk el a szennyeződésektől. Jobb oldalon a kromatogram frakcióinak SDS-poliakrilamid gél képe látható.

\subsubsection{Fehérje- $\mathrm{Zn}^{2+}$ kölcsönhatás vizsgálata tömegspektrometriával}

Az ioncsere kromatográfiával történő elválasztás után az egyes frakciókat SDSPAGE ellenőrizve, alátámasztottuk az egyes fehérjék tisztaságát majd MS mérésekkel egyértelmüen azonosítottuk őket. A $\Delta \mathrm{N} 25-\mathrm{NColE7}$ fehérje esetében az apo fehérjére számított és mért molekulatömeg jó egyezést mutatott, vagyis a tisztított fehérje nem tartalmaz $\mathrm{Zn}^{2+}$-iont. A továbbiakban a fehérje oldatát $\mathrm{Zn}^{2+}$-ionok oldatával titráltuk. 120 ekvivalensnyi $\mathrm{Zn}^{2+}$-ion hozzáadása közben követtük a holo-fehérje megjelnését. $\mathrm{E}$ vizsgálatok alapján a fehérje mintegy $50 \%$-a képes megkötni a fémiont $10 \times$, és $\sim 80 \%$-a $20 \times \mathrm{Zn}^{2+}$-felesleg jelenlétében (5.2.2.1. ábra) 


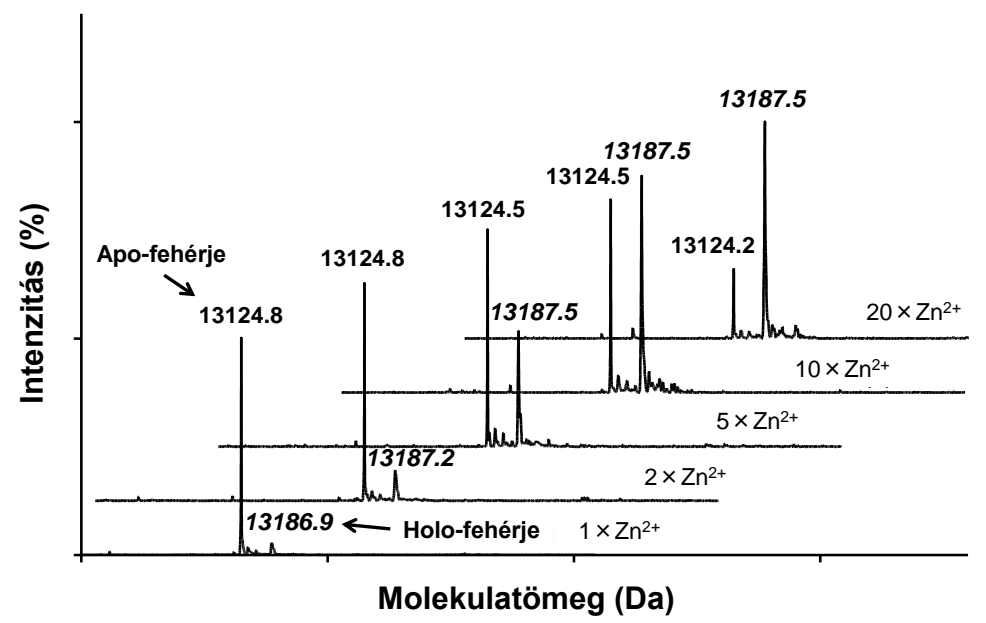

5.2.2.1. ábra: Növekvő $\mathrm{Zn}^{2+}$-koncentráció mellett tapasztalt apo-, és holo-fehérje arány változása a $\Delta \mathrm{N} 25-\mathrm{NColE} 7$ fehérje tömegspektruma alapján. A holo-fehérje aránya folyamatosan növekszik a $\mathrm{Zn}^{2+}$ ionok hozzáadásának hatására, azonban még húszszoros fémion-felesleg jelenlétében sem kvantitatív a képződése. (A $\triangle \mathrm{N} 25-\mathrm{NColE7}$ számolt molekulatömege $\mathrm{Zn}^{2+}$-ion távollétében 13123,7 $\mathrm{Da}, \mathrm{Zn}^{2+}$-ion jelenlétében pedig 13189,08 Da).

Ugyanakkor a $\Delta \mathrm{N} 4-\mathrm{NColE7}$ mutáns fehérje (4 N-terminális aminosav hiány) a tisztítási folyamatok során is képes volt a $\mathrm{Zn}^{2+}$-iont kötésben tartani (5.2.2.2. ábra). Ez annál inkább figyelemreméltó, mivel a GST oszlopról $15 \mathrm{mM}$ redukált glutation jelenlétében - mely tiolcsoportja révén jó fémionkötő sajátsággal bír - is a fehérjéhez kötve maradt a $\mathrm{Zn}^{2+}$-ion. Eszerint a $\Delta \mathrm{N} 25-\mathrm{NColE7}$ fehérje gyengébb fémkötő tulajdonsággal rendelkezik, mint a $\triangle \mathrm{N} 4-\mathrm{NColE7}$.

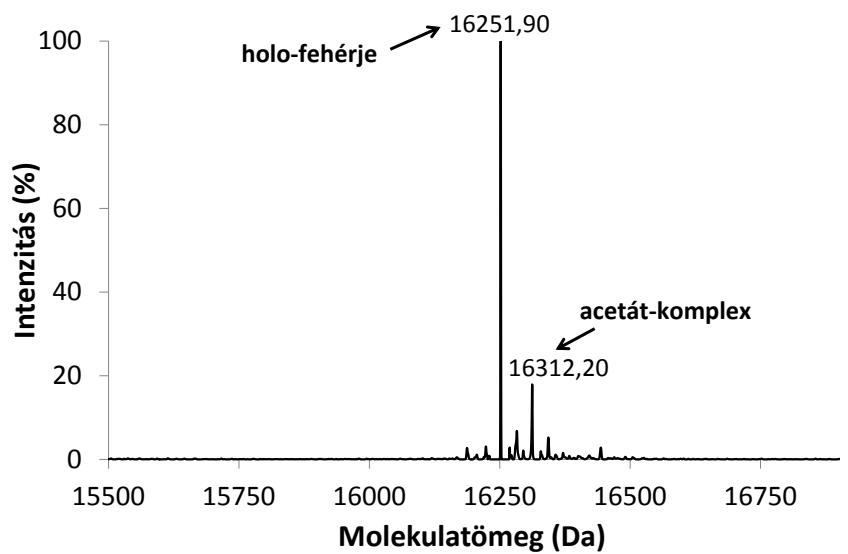

5.2.2.2. ábra: $\triangle \mathrm{N} 4-\mathrm{NC}$ ClE7 fehérje tisztítás után mért tömegspektruma. Az apo $\Delta \mathrm{N} 4-\mathrm{NColE} 7$ számított molekulatömege $16188,0 \mathrm{Da}$, a $\mathrm{Zn}^{2+}$-ionokat is tartalmazó holo fehérjére vonatkozó számított érték $\mathrm{Zn}^{2+}$ ion jelenlétében pedig 16253,5 Da (A molekulatömegekre vonatkozó magyarázat ld. a következő fejezetben). 
A $\triangle$ N4-NColE7 fehérje 5.2.1. ábrán feltüntetett szekvenciája alapján várt molekulatömege 15258,2 Da. Viszont a $\mathrm{Zn}^{2+}$-ion nélküli fehérje mért molekulatömege 16188,1 Da volt. Ennek magyarázata, hogy a C-terminális végen nem várt mutáció jelent meg (5.2.2.3. ábra). Ez a mellékreakció a PCR során játszódott le egy hibás ColE7 inverz (ld. 5.2.1. táblázat) oligonukleotid molekula hibridizációja során.

Mivel annak a valószínüsége, hogy a gyártó (Hokkaido System Science Co., Ltd., Japán) által forgalmazott primer frakcióban hibás oligonukleotidok lehetnek nagyon kicsi, azt kell feltételezünk, hogy a transzformálás során azok az E.coli baktériumok, melyek a hibátlan GST- $\triangle \mathrm{N} 4-\mathrm{NColE7}$ gént tartalmazták, annak toxikus hatása miatt nem tudtak elszaporodni. Ez vezetett oda, hogy az életképes bakériumokból egy további mutációt tartalmazó nem toxikus fehérjét izoláltunk. A hibás primer az olvasási keret eltolódását eredményezte, így a kifejezett fehéje C-terminális vége a pGEX-6P1 vektorban található első STOP kodon eléréséig meghosszabbodott. Az új fehérje szekvenciája a vektor segítségével meghatározható, aminek alapján a számított molekulatömeg megegyezett a mért értékkel.

A fentiek igazolására többféle baktériumsejtet is traszformáltunk a $\Delta \mathrm{N} 4-\mathrm{NColE} 7$ fehérje génjét tartalmzó pGEX-6P1 plazmiddal. Ezek közül az XL10 Gold (Stratagene) baktériumtörzsből sikerült izolálni a hibátlan gént, azonban ennek segítségével nem sikerült a fehérjét kifejezni, ami alátámasztotta annak citotxikus hatását. Mivel a munkának ebben a fázisában nagymennyiségű tisztított fehérje állt rendelkezésünkre és a HNH motívumot, azaz a számunkra fontos aminosavakat nem érintette a mutáció, így feltételezésünk szerint ez nincs lényeges hatással a fehérje fémion, ill. DNS-kötésére nézve. Ezért a továbbiakban ezen fehérjével dolgoztunk tovább, és ezen szekvenciát értem a $\triangle \mathrm{N} 4-\mathrm{NColE7-C*}$ jelölés alatt. A későbbiekben a C-terminális mutáció hatására is kitérek majd (5.3.3. fejezet).

$\begin{array}{ll}\Delta \text { N4-NCoIE7-C* } & \text { GPLGSPEFPGKATGKGKPVNNKWLNNAGKDLGSPVPDRIANKLRDKEFK } \\ 16188,1 \mathrm{Da} & \text { SFDDFRKKFWEEVSKDPELSKQFSRNNNDRMKVGKAPKTRTQDVSGKRT } \\ & \text { SFELHHEKPISQNGGVYDMDNISVVTPKRHIDIHQVNSSSGRIVTD } \\ & \\ & \\ \text { NN4-NColE7 } & \text { GPLGSPEFPGKATGKGKPVNNKWLNNAGKDLGSPVPDRIANKLRDKEFK } \\ 15285,2 \mathrm{Da} & \text { SFDDFRKKFWEEVSKDPELSKQFSRNNNDRMKVGKAPKTRTQDVSGKRT } \\ & \text { SFELHHEKPISQNGGVYDMDNISVVTPKRHIDIHRGK }\end{array}$

5.2.2.3. ábra: A $\triangle N 4-N C o l E 7-C^{*}$ mutáns aminosav-szekvenciája összehasonlítva a várt szekvenciával. A C-terminális végen fellépő mutációt rózsaszínnel jelöltük. Kékkel, a GST fúziós rész eltávolítása után a proteáz felismerési helyet magába foglaló maradvány szekvencia látható. $\triangle$ N4-NColE7 jelöli a Cterminális mutáció nélküli szekvenciát. 


\subsubsection{Fehérje $-\mathrm{Zn}^{2+}$ kölcsönhatás tanulmányozása fluorimetrás mérésekkel}

A fehérje-fémion kölcsönhatására nézve kvalitatív információkhoz juthatunk a 490 nm-nél mért maximális fluoreszcencia intenzitás vizsgálatával.

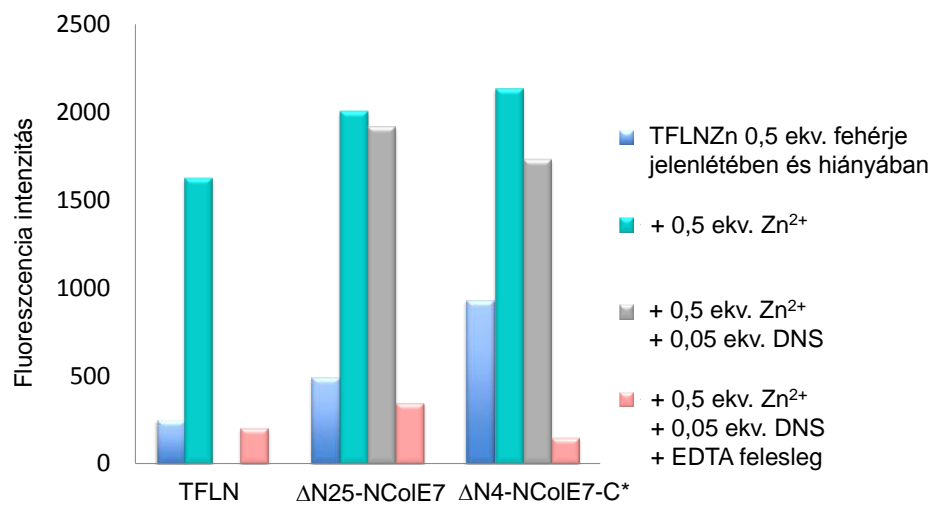

5.2.3.1. ábra: A TFLZn festék 490 nm-nél mérhető maximális fluoreszcenciájának intenzitása különböző reaktánsok jelen-, ill. távollétében.

$\mathrm{Az}$ 5.2.3.1. ábra első két oszlopa a TFLZn festék maximális fluoreszcencia intenzitását mutatja $\mathrm{Zn}^{2+}$-ion távollétében, illetve fél ekvivalensnyi $\mathrm{Zn}^{2+}$-ion hozzáadására. Látható, hogy az intenzitás jelentősen megnő $\mathrm{Zn}^{2+}$-ionok jelenlétében a Zn(TFLZn) $)_{2}$ összetételü komplex kialakulásának következtében, majd visszatér az eredeti állapotba EDTA hozzáadására. Ez utóbbi reaktáns multidentát ligandum révén képes a fluoreszcens festéket kiszorítani a $\mathrm{Zn}^{2+}$-ion koordinációs szférájából. A TFLZn festéket tartalmazó oldatok fél ekvivalensnyi NColE7 mutáns hozzáadása után különböző viselkedést mutattak. $\Delta \mathrm{N} 25-\mathrm{NColE7}$ fehérje jelenléte nem okozott jelentős változást a fluoreszcenciában, míg a $\Delta \mathrm{N} 4-\mathrm{NColE7}-\mathrm{C}^{*}$ mutánst a festékhez hozzáadva megnőtt az intenzitás. Mindkét így létrehozott oldathoz a fehérjével ekvivalens mennyiségü $\mathrm{Zn}^{2+}$-ionokat adva nőtt az intenzitás. Ezek az eredmények a már bemutatott tömegspektrumokkal jó egyezést mutatnak. Azaz a $\Delta \mathrm{N} 25-\mathrm{NColE7}$ fehérjét $\mathrm{Zn}^{2+}$-ion nélkül sikerült tisztítanunk, és a hozzáadott fémiont is gyengén kötötte. $\mathrm{A} \mathrm{Zn}^{2+}$-ion koordinációs szférájából nem képes a festékmolekulát (TFLZn) kiszorítani. Ebben az esetben Zn(TFLZn) $)_{2}$ komplex képződik, hasonló módon, mint a Zn-TFLZn biner rendszerben. Azonban a fluoreszcencia intenzitása nagyobb a fehérje jelenlétében, mint a biner rendszerben. 
A $\Delta$ N4-NColE7-C* fehérjéröl tudjuk, hogy 1 ekvivalens $\mathrm{Zn}^{2+}$-iont köthet meg, mégis a fluoreszcencia intenzitásának növekedését tapasztaltuk a fehérjét a TFLZn festékhez hozzáadva. Magyarázat lehet erre, valamint a megnövekedett intenzitásra a $\triangle \mathrm{N} 25-\mathrm{NColE7}$ jelenlétében, hogy ezen fehérjékben a $\mathrm{Zn}^{2+}$-ionnak csak 3 koordinációs helyét töltheti ki a három His oldallánca, így a szabadon maradt hely(ek)re beköthet egy festékmolekula, azaz Zn-fehérje-TFLZn terner komplex kialakulása is lehetséges. Ebben ez esetben további $\mathrm{Zn}^{2+}$-ion hozzáadására az intenzitás tovább növelhető, mivel a TFLZn próba feleslegben van az 2:1:1 oldatban.

EDTA felesleg hozzáadása a fenti rendszerekhez minden esetben a fémion nélküli festékmolekula intenzitásához hasonló értékre csökkentette a fluoreszcenciát csakúgy, mint fehérje nélkül ugyanebben az összeállításban. Tehát az EDTA erősebben köti a $\mathrm{Zn}^{2+}$-iont, mint a fehérjéink.

\subsubsection{Cirkuláris dikroizmus a fehérje- $\mathrm{Zn}^{2+}$-ion kölcsönhatás vizsgálatában}

$\mathrm{Az}$ NColE7 mutánsainak a fémion megkötését $\mathrm{Zn}^{2+}$-ionok, illetve EDTA hozzáadására bekövetkező spektrális változások alapján vizsgáltuk egy szinkrotron sugárzást alkalmazó $\mathrm{CD}$ spektroszkóp segítségével. A $\Delta$ N4-NColE7-C* fehérje spektrumait az 5.2.4.1. (A) ábra mutatja.

(A)

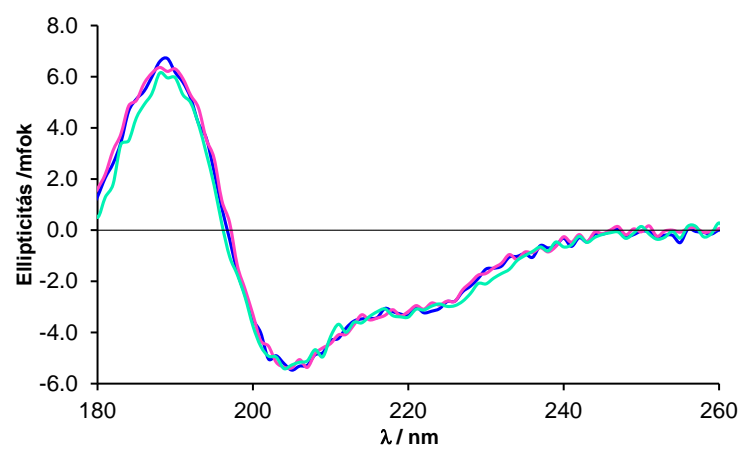

(B)

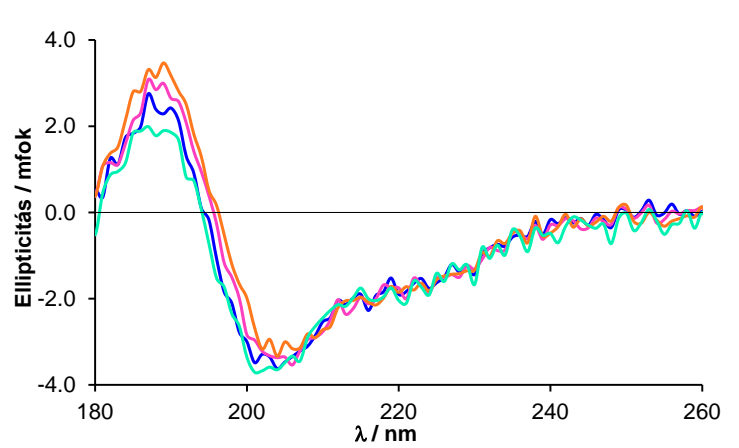

5.2.4.1. ábra: $A \Delta N 4-N C o l E 7-C *(A)$ illetve a $\triangle N 25-N C o l E 7$ (B) fehérjék $S R C D$ spektrumai különböző körümények között. A fehérjék vizes oldatának spektrumát kék, egy ekvivalens $\mathrm{Zn}^{2+}$-ion jelenlétét a fehérje mellett ciklámen szín jelöli. A GST- $\Delta \mathrm{N} 25-\mathrm{NColE7}$ fehérje esetében narancs színnel $10 \times \mathrm{Zn}^{2+}$ felesleg jelenlétében felvett spektrumot ábrázoltuk. Zölddel jelöltük azokat a spektrumokat, melyeket EDTA-felesleg hozzáadása után rögzítettünk. 
A $\triangle$ N4-NColE7-C* fehérje SRCD spektrumain jól látható, hogy nem történik számottevő változás $\mathrm{Zn}^{2+}$-ionok hozzáadása után, de még $5 \times \mathrm{Zn}^{2+}$-felesleg jelenlétében sem (utóbbi nem szerepel az ábrán). Ez alátámasztja a fentieket, miszerint $\Delta \mathrm{N} 4$ NColE7-C* fehérjét $\mathrm{Zn}^{2+}$-komplexe formájában sikerült tisztítani. EDTA felesleg hozzáadása alig észrevehető változást okoz a spektrumban. Ennek oka, hogy bár az EDTA felesleg képes a fémiont elvonni a fehérjétöl, ez a mérési körülményeink között vagy nem valósult meg teljes mértékben, vagy a fémion elvonása nem okozott jelentős szerkezetváltozást.

A $\triangle$ N25-NColE7 fehérje viselkedése eltér a fentiektől. Az SRCD spektrumok intenzitása és alakja folyamatosan változott a növekvő $\mathrm{Zn}^{2+}$-ion koncentráció hatására egészen a 10× feleslegig. EDTA felesleg hozzáadásakor jó közelítéssel ugyanazt a spektrumot mértük, mint $\mathrm{Zn}^{2+}$-ion hiányában. Ez az eredmény ugyancsak alátámasztja, hogy a rövidebb $\Delta \mathrm{N} 25-\mathrm{NColE7}$ fehérje jelentősen gyengébb fémkötő tulajdonsággal rendelkezik, mint a $\Delta \mathrm{N} 4-\mathrm{NColE7}-\mathrm{C}^{*}$ fehérje. Azaz az N-terminális 21 aminosavak hiánya hatást gyakorol a C-terminális vég $\mathrm{Zn}^{2+}$-kötésére. Ugyanakkor az is jól látható, hogy a $\triangle \mathrm{N} 25-\mathrm{NColE7}$ fehérje szerkezeti változást szenved a fémion hozzáadására, azaz fémion nélkül nem képes a natív szerkezetét megtartani. Ez a változás nagyrészt valószínűleg a C-terminális részen található aktív központhoz rendelhető, amiből arra következtethetünk, hogy az N-terminális rész befolyásolja az aktív központ szerkezetét.

\subsubsection{Fehérje-DNS kölcsönhatás vizsgálata SRCD spektroszkópiával}

Az SRCD spektroszkópiát felhasználtuk fehérje-DNS kölcsönhatás tanulmányozására is. A DNS jelenlétében mért spektrumokat a 5.2.5.1. ábra mutatja. A komponensek spektrumait a mérési körülményeknek megfelelő arányban összegezve kiszámítottunk egy olyan spektrumot, mely a kölcsönhatás nélküli keverékre jellemző. Ezt a számított spektrumot hasonlítottuk össze a mért spektrummal. 
(A)

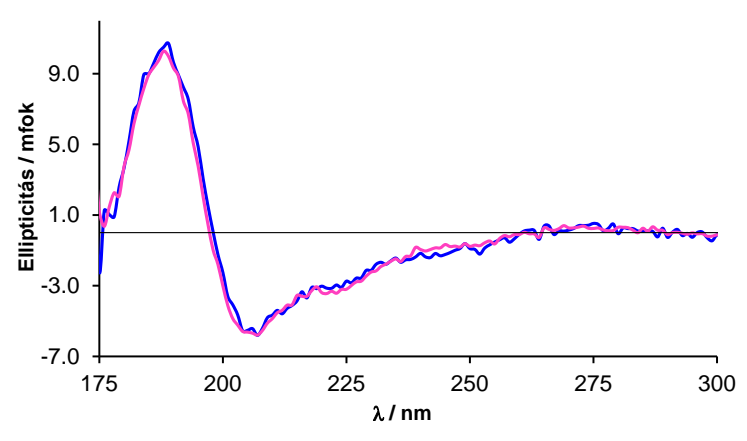

(B)

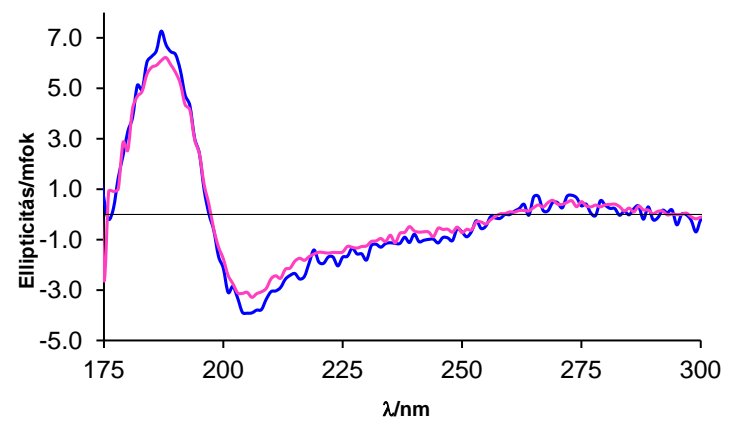

5.2.5.1. ábra: $\Delta \mathrm{N} 4-\mathrm{NColE7}-\mathrm{C}^{*}$ (A) és $\Delta \mathrm{N} 25-\mathrm{NColE7}$ (B) fehérjék SRCD spektrumai DNS jelenlétében. Az ábrákon kékkel jelöltük a komponensek spektrumai alapján számított, ciklámennel pedig a mért spektrumokat.

A $\triangle$ N4-NColE7-C* fehérje esetében a két spektrum jó egyezést mutat, ami kétféleképpen értelmezhető: nincs szignifikáns szerkezetváltozás a kölcsönhatás következtében, vagy nincs kölcsönhatás a molekulák között. EDTA hozzáadása ehhez a rendszerhez sem okozott jelentős változást (nincs ábrázolva), ami az első verzió megvalósulása esetén arra utal, hogy a $\mathrm{Zn}^{2+}$-ion eltávolítása nem von maga után szerkezetbeli változást, illetve nem hiúsítja meg a DNS megkötését.

A $\triangle$ N25-NColE7 fehérje esetében eltérést tapasztaltunk a mért és a számított spektrumok között. Eszerint a fehérje konformációja kismértékben megváltozik a DNSsel kialakított kölcsönhatás során: valószínüleg a mutáns flexibilis szerkezete az NColE7 szerkezetet közelítve stabilizálódik. E változás azonban mindenképpen arra utal, hogy a fehérje képes a DNS-hez kötődni.

\subsubsection{Gél mobilitás vizsgálatok}

A colicin E7 nukleáz doménjének (NColE7) nem-specifikus DNS kötése és hasítása ismert. Irodalmi adatok alapján legalább 8 bp hosszúságú DNS molekula jelenléte szükséges a kötődéshez. Agaróz gélben a fehérjéhez kötődött DNS molekula mobilitása megváltozik, így a kölcsönhatásuk követhető. Az ilyen jellegü vizsgálatokat egy 196 bp és 2700 bp hosszúságú DNS molekulákat tartalmazó DNS keverékkel végeztük. A kisebb DNS fragmens, akár 20 fehérjemolekulát is megköthet, míg a nagyobb molekula több mint 250 kötőhelyet tartalmazhat. Kísérleteinkben különböző fehérje:DNS-kötőhely (ahol a DNS kötőhelyet a fentiek alapján 10 bp hosszúságúnak 
tekintettük) arányokat vizsgáltunk 0,5:1 és 50:1 között. Különböző sókoncentráció $(\mathrm{NaCl})$, feszültség, puffer (PBS, Tris), festék, a glutation fúziós rész meglétének vagy hiányának, illetve $\mathrm{Zn}^{2+}$-ionoknak a DNS-fehérje kölcsönhatásra gyakorolt hatását vizsgáltuk. A különböző körülmények között elvégzett gélelektroforézis során nem tapasztaltunk szignifikáns változást a fehérjék okozta sáveltolódásban. Az eredmények alapján a (GST)- $\Delta \mathrm{N} 4-\mathrm{NColE7}-\mathrm{C}^{*}$ fehérje képes mind a rövidebb, mind a hosszabb DNS fragmens megkötésére (5.2.6.1. ábra). Az itt megfigyelteknél jóval kisebb mértékü eltolódás tapasztalható az agaróz gélen, GST- $\Delta$ N25-NColE7 esetében. Kis fehérje:DNS aránynál nem tapasztaltunk géleltolódást, a fehérje növekvő feleslegének hatására viszont (10:1) látható az eltolódás mértéke. A kötődés aspecifikusságát elmaszatolódás jelzi az agaróz gélen, ahogy az az 5.2.6.1. (A) ábrán a 7-es oszlopban jól látható. A fehérje feleslegének további növekedése (50:1), jelentős aggregáció lépett fel megakadályozva a migrációt a gélben (ábrán nincs feltüntetve).

(A)

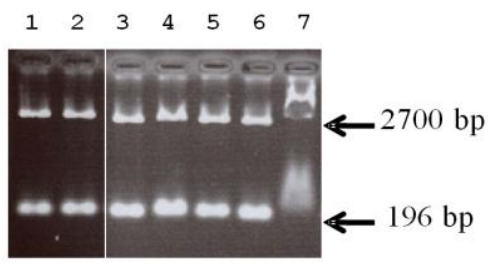

(B)

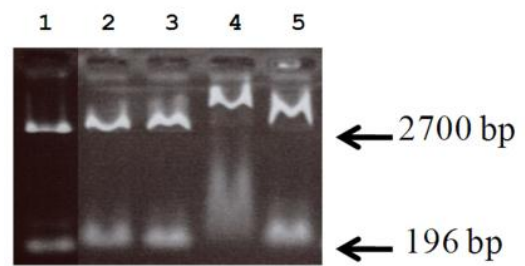

5.2.6.1. ábra: Gél-mobilitás vizsgálatok a GST- fúziós fehérje-DNS kölcsönhatás felderítése céljából. Szubsztrátként 100 ng emésztett 5SrDNS-t használtunk, amely két elkülönült sávot alkot a gélen, 196 bp és egy 2700 bp méretben. A fehérje koncentrációja 0,4-2,0 mg/ml között változott a különböző mutánsok esetében. (A) Az oszlopok sorrendjében: (1) GST:DNS, 1,5:1; (2) GST:DNS, 15:1; (3) GST- $\Delta$ N25-

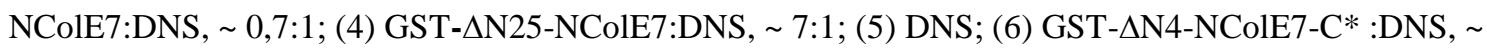
1:1; (7) GST- $\triangle$ N4-NColE7-C*: DNS, 10:1. (B) Fehérje-DNS kölcsönhatás a GST fúziós rész eltávolítása - PreScission proteázzal való emésztés - után. A reakció körülményei megegyeztek az (A) ábrán feltüntettekkel. A zsebek tartalma az oszlopok sorrendjében: (1) DNS; (2) GST- $\Delta$ N25NColE7:DNS, 9:1; (3) $\Delta$ N25-NColE7:DNS, 9:1 (4) GST- $\triangle$ N4-NColE7-C* :DNS, 28:1; (5) $\Delta$ N4NColE7-C* :DNS, 28:1.

A GST fúziós rész nélküli fehérjemutánsok DNS kötését is megvizsgáltuk. Ehhez a megtisztított fúziós fehérjéket PreScission proteázzal hasítottuk, majd a megfelelő affinitás alapú kromatográfiás eljárást alkalmazva megtisztítottuk. A különböző mutáns fehérjék kölcsönhatását DNS-sel ugyanolyan körülmények között vizsgáltuk, mint a fúziós részt tartalmazó fehérjék esetén. A gél-mobilitás változásokból látható, hogy a GST- $\triangle \mathrm{N} 4-\mathrm{NColE7}-\mathrm{C}^{*}$ fehérje (5.2.6.1. (A) ábra 7. oszlop és 5.2.6.1. 
(B) ábra 4. oszlop) erősen kötődik a DNS molekulához. Az eltolódás mértéke ugyan a GST-t tartalmazó fehérjéhez képest csökkent, ami ezen fúziós rész hiányából adódó méretcsökkenés következményeként magyarázható (5.2.6.1. (B) ábra 4-es, 5-ös oszlop). Kismértékű sáveltolódás a GST- $\Delta$ N25-NColE7 mutáns esetében is tapasztalható (5.2.6.1. (B) ábra 3-as oszlop).

A $\quad \Delta \mathrm{N} 25-\mathrm{NColE7}, \quad \Delta \mathrm{N} 4-\mathrm{NC}$ ColE7-C* mutánsok DNS-kötő képességének összehasonlítása céljából további kísérleteket végeztünk. Egyre növekvő mennyiségü fehérje jelenléte mellett vizsgáltuk a fehérje-DNS komplexek mobilitását agaróz gélen (400 bp hosszúságú DNS, $0,874 \mu \mathrm{M}$ 5.2.6.2. ábra). A $\Delta \mathrm{N} 25-\mathrm{NColE7}$ fehérjéből tízszer nagyobb fehérje-koncentrációt kellett alkalmaznunk, mint a $\triangle \mathrm{N} 4-\mathrm{NColE} 7-\mathrm{C}^{*}$ esetében, az előbbi gyengébb kötődésének megfelelően.

(A)

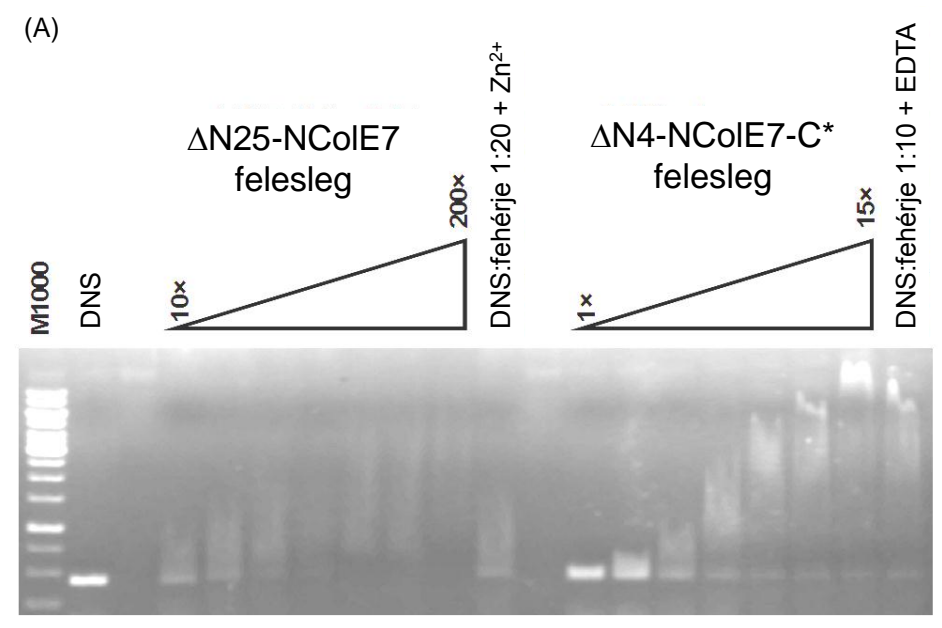

(B)

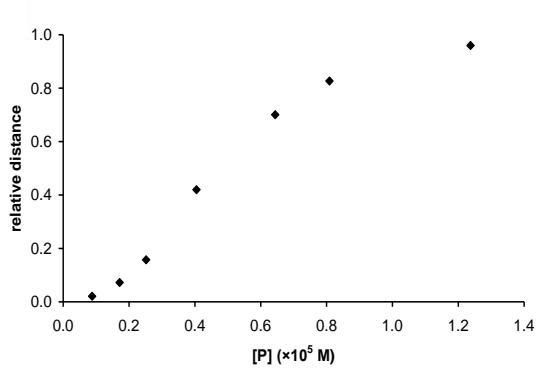

5.2.6.2. ábra (A) rész: A gél-mobilitás vizsgálatok gélelektroforézis képe: a $\Delta \mathrm{N} 25-\mathrm{NColE} 7$ és $\Delta \mathrm{N} 4-$ NColE7-C* fehérjék DNS kötésének tanulmányozása. Az első oszlop 1000 bp-os marker DNS elegyet tartalmaz. A második oszlopban a DNS minta látható fehérje távollétében, a harmadik oszloptól kezdve azonos mennyiségű DNS-t egyre növekvő mennyiségű fehérjével inkubáltunk. A $\Delta$ N25-NColE7 fehérjét sorrendben 10, 20, 30, 50, 80, 100, 200-szoros a $\Delta$ N4-NColE7-C* fehérjét pedig rendre 1,3,5,8,10,20szoros mennyiségben alkalmaztuk a 10 bp hosszúságú DNS kötőhelyekre vetítve.

(B) rész: A $\triangle \mathrm{N} 4-\mathrm{NColE7-C} *$ fehérje DNS-sel kialakított kölcsönhatása következményeként megfigyelhető relatív géleltolódás mértékét ábrázolja az egyensúlyi fehérjekoncentráció függvényében. A gélen lévő szabad DNS és a fehérjével telített DNS sávja közötti távolságot egységnyinek tekintettük.

$\mathrm{Zn}^{2+}$-iont adva a $\Delta \mathrm{N} 25-\mathrm{NColE7} 20$-szoros feleslegét tartalmazó oldathoz, nem történt jelentős változás a sáv helyzetében a $\mathrm{Zn}^{2+}$-iont nem tartalmazó azonos összetételü elegy sávjához képest. Ennek oka lehet az, ha a fehérje már kötött fémiont 
tartalmaz. Ez azonban ellentmondana az előző eredményeinknek. Ebből következik, hogy a $\mathrm{Zn}^{2+}$-ion kötése nem szükséges a DNS kötéshez, hasonlóan a NColE7-hez [73]. Ez utóbbit igazolandó EDTA-felesleget adtunk a $\triangle \mathrm{N} 4-\mathrm{NColE7-C} *$ - DNS rendszerhez, ami szintén nem okozott változást a DNS sáv helyzetében. A $\triangle \mathrm{N} 4-\mathrm{NColE7-C} *$ fehérje esetében egy közelítő látszólagos disszociációs állandó becsülhető a gél-mobilitás vizsgálatok alapján. Feltéve, hogy a fehérje 1:1 arányban alkot komplexet (P-DNS) a 10 bp hosszúságú DNS- szakaszokkal minden kötőhelyre fehérje kötődhet. Az 5.2.6.2. (B) ábrán a gélmobilitás vizsgálatok alapján a relatív sáveltolódást ábrázoltuk az egyensúlyi fehérjekoncentráció $[\mathrm{P}]$ függvényében. Ez utóbbit $[\mathrm{P}]=\mathrm{c}_{\mathrm{P}}-[\mathrm{P}-\mathrm{DNS}]$ alapján becsültük meg, ahol $\mathrm{c}_{\mathrm{P}}$ a teljes fehérjekoncentráció és [P-DNS] a fehérje-DNS egyensúlyi koncentrációja, ami arányos a kötésben nem lévő DNS-től mért géleltolódás mértékével. Mivel $\mathrm{K}_{\mathrm{D}}=([\mathrm{P}] \times[\mathrm{DNS}]) /[\mathrm{P}-\mathrm{DNS}]$, az inflexiós pontban, a DNS $50 \%$-a a fehérjével komplexet alkot $([\mathrm{DNS}]=[\mathrm{P}-\mathrm{DNS}])$, és így $[\mathrm{P}]=K_{D}$, ahol $K_{D}$ a látszólagos disszociációs állandó. Ennek a fentiek alapján becsült értéke pedig $\sim 5,0 \mu \mathrm{M}\left(\mathrm{pK}_{\mathrm{D}} \sim\right.$ 5,3) a $\Delta$ N4-NColE7-C* -DNS kötésére nézve. 


\subsubsection{Eredmények és tárgyalásuk}

Miután a HNH motívumról bebizonyítottuk, hogy nem rendelkezik nukeláz aktivitással, 4 különböző NColE7 N-terminális részen rövidített mutánst fejeztünk ki a citotoxikus hatás vizsgálata céljából. Az 5.2.2. ábrán látható, hogy a mutáns fehérjék kifejezésének hatására a baktériumsejtek nem pusztulnak el, azaz a fehérjék valószínűleg nem rendelkeztek nukleáz aktivitással, mindaddig amíg az utolsó $4 \mathrm{~N}$ terminális aminosavat is vissza nem építettük. Az, hogy a DNS kötésében szerepet játszó aminosav oldalláncok visszaépítése során sem sikerült visszanyernünk a nukleáz aktivitást, váratlan eredmény volt. Következésképpen a fehérje aminosavszekvenciájában távol eső szakaszok jelenléte szükséges az enzimatikus aktivitás kialakításához, ami előre vetíti egy allosztérikus aktiválás lehetőségét. Ez nagy jelentőséggel bírhat egy mesterséges metallonukleáz fejlesztésében. Éppen ezért a továbbiakban arra kerestük a választ, hogy mi a szerepe az N-terminális aminosavaknak. Ehhez elsőként az N-terminális végen 4, illetve 25 aminosavval csonkított mutánsok vizsgálatát tüztük ki célul, hogy megfigyeljük, milyen változásokat von maga után az N-terminális részek eltávolítása. A fehérjekifejezés és tisztítás optimalizálása után (5.2.1. fejezet) a tiszta fehérjék $\mathrm{Zn}^{2+}$-kötését vizsgáltuk meg elsőként, tudván, hogy a HNH motívum gyengén kötötte a $\mathrm{Zn}^{2+}$-ionokat. A $\Delta \mathrm{N} 4$ NColE7 mutáns génje a pGEX-6P-1 vektorba ligálva a természetes NColE7-hez hasonlóan mérgezőnek bizonyult, így a baktériumsejtekből egy C-terminális módosítással sikerült azt izolálni. Mivel ez a módosítás fehérje funkciója szempontjából lényeges aminosavakat nem érintette, ezzel a fehérjével a $\Delta N 4-N C o l E 7-C^{*}$ néven foglalkoztunk tovább. A $\Delta \mathrm{N} 4-\mathrm{NColE7-C} \mathrm{C}^{*}$ mutánst $\mathrm{Zn}^{2+}$-kötött formában detektáltuk a tömegspektruma alapján (5.2.2.2. ábra), azaz a fehérje a tisztítási folyamat során végig képes volt a fémiont kötésben tartani. Ugyanakkor a tisztított $\Delta \mathrm{N} 25-\mathrm{NColE7}$ mutáns nem tartalmazott $\mathrm{Zn}^{2+}$-iont. A tömegspektrumok alapján még $20 \times \mathrm{Zn}^{2+}$-felesleg hozzáadására is csak a fehérje $80 \%$-a volt képes fémiont megkötni. Meglepő, hogy az eltávolított flexibilis hurokszerü N-terminális fehérjerészlet milyen nagy hatással van a C-terminális végen történő, jól megőrzött $\mathrm{HNH}$ motívum $\mathrm{Zn}^{2+}$-kötésére. Elképzelhető, hogy a két vég közötti kölcsönhatások, a HNH motívum ilyen mértékü szerkezetbeli stabilitását eredményezik? Erre nézve a két fehérje eltérő $\mathrm{Zn}^{2+}$-, és DNS-kötését, illetve ezek szerkezetre gyakorolt hatását CD spektroszkópiás módszerrel is megvizsgáltuk 
(5.2.4.1. ábra). Kimutattuk, hogy a rövidebb mutáns gyengébb fémion-kötő képessége valószínüleg a szerkezet megváltozásának tudható be.

Ahogy az már a legelső kísérleteinkből kiderült, egyik mutáns sem rendelkezett nukleáz aktivitással, de arról, hogy a DNS-sel kölcsönhatásba lépnek-e nem kaptunk információt. Erre nézve további kísérleteket végeztünk (5.2.5.1. ábra). A DNS és a fehérje komponens CD spektrumokból kiszámítottuk a kölcsönhatásmentes, kísérleti körülményeknek megfelelö összetételü elegy $\mathrm{CD}$ spektrumát, amelyet összehasonlítottunk a mért görbével. A $\Delta$ N4-NColE7 mutáns esetében a számított és a mért érték nagyon jó egyezést mutatott (5.2.5.1. (A) ábra), míg a $\triangle \mathrm{N} 25-\mathrm{NColE7}-\mathrm{C}^{*}$ mutáns esetén eltérések tapasztalhatók. Ezek alapján gondolhatunk arra is, hogy a $\Delta \mathrm{N} 4$ NColE7-C* fehérje nem képes a DNS-hez kötődni. Valójában az irodalmi adatok arra utalnak, hogy az NColE7 fehérje olyan stabil szerkezettel bír, hogy a DNS-hez való kötődése nem von maga után szerkezet-változást. Ugyanakkor a $\Delta$ N25-NColE7 esetében a DNS kötődésekor szerkezet változást-detektáltunk. Tehát a $\Delta \mathrm{N} 25-\mathrm{NColE7}$ fehérje esetében az eltávolított aminosavak egy rendezetlenebb szerkezetet eredményeznek, amelyet a DNS-hez kötődés (részben) helyreállít. A fehérje-DNS kölcsönhatást agaróz gélelektroforézissel (5.2.6.2. ábra) vizsgáltuk. A rövidebb mutáns esetén még a 200× feleslegben alkalmazott fehérje sem tudta telíteni a DNSkötőhelyeket, míg a $\Delta \mathrm{N} 4-\mathrm{NColE7-C*}$ mutáns esetében már $15 \times$ fehérje feleslegnél elértük a DNS telítését. Tehát a $\triangle \mathrm{N} 25-\mathrm{NColE7}$ fehérje esetén, az eltávolított aminosavak a $\mathrm{Zn}^{2+}$, és a DNS-kötés mértékét is jelentősen csökkentették, ami az eltávolított rész fontos szerepére utal. Ugyanakkor a két mutáns fehérje viselkedésében megmutatkozó különbség azt is sugallja, hogy az N-terminális hurok szerkezete a $\Delta \mathrm{N} 4$ NColE7-C* mutánsban az NColE7 fehérjében lévő szerkezethez hasonló lehet.

Az azonban, hogy a $\Delta \mathrm{N} 4-\mathrm{NColE7-C} *$ fehérje bár köti a fémiont, és DNS-t is, de mégsem képes elhasítani ez utóbbit, az N-terminális pozitív töltésű oldalláncok eltávolításának következménye lehet. E feltételezéseket a fehérje szerkezet meghatározásán keresztül szándékoztunk igazolni. 


\subsection{A $\Delta$ N4-NColE7 szerkezetmeghatározás vizsgálatai}

\subsubsection{A fehérjék kristályosítása}

Hogy tisztázzuk az N-terminális aminosavak, illetve azok hiányának katalitikus központra gyakorolt hatását, a fehérje pontos térszerkezetének meghatározását tüztük ki célul. Első lépésben kristályosítási kísérleteket végeztünk. Ehhez szükséges nagymennyiségü, tiszta fehérjét állítottunk elö a $\Delta \mathrm{N} 25-\mathrm{NColE7}$ és $\Delta \mathrm{N} 4-\mathrm{NColE7-C} *$ mutánsokból. Számos kristályosítási körülmény kipróbálása után, végül a JCSG+ screenben (F.8. táblázat) találtunk olyan körülményt, amely fehérje egykristályt eredményezett a $\triangle \mathrm{N} 4-\mathrm{NColE7}-\mathrm{C}^{*}$ fehérje esetében (5.3.1.1. ábra).
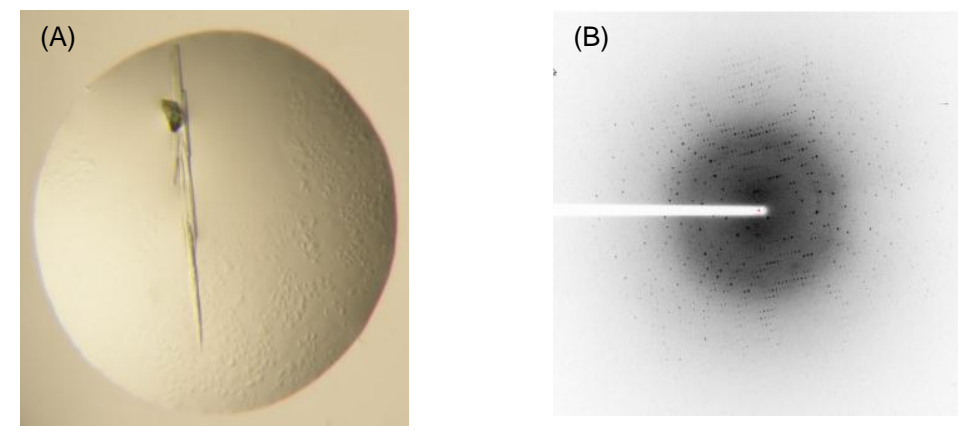

5.3.1.1. ábra: $\triangle \mathrm{N} 4-\mathrm{NColE7- \textrm {C } ^ { * }}$ fehérje egykristály fényképe és a kristályról készült röntgendiffraktogram. A kristályosító oldat tartalma: 0,2 $\mathrm{M}$ lítium-szulfát, $0,1 \mathrm{M}$ nátrium-acetát $\mathrm{pH}=4,5,50 \%$ w/v, PEG 400, a fehérje-koncentráció $28 \mathrm{mg} / \mathrm{ml}$. A kristály mérete $500 \times 50 \times 50 \mu \mathrm{m}$.

Ez a kristály alkalmas volt röntgen-diffrakciós mérésre. A diffraktogram alapján a fehérje szerkezetének megfejtésében dán együttmüködő partnereinkre támaszkodtunk. A $\triangle$ N4-NColE7-C* fehérje $\mathrm{P} 3{ }_{2} 21$ kristálytér szimmetriát mutat, ahol az elemi cella méretei $\mathrm{a}=55,3, \mathrm{~b}=55,3, \mathrm{c}=73,1 \AA$ A. Ahogy, azt már az 5.2.2. fejezetben említettük, a $\Delta$ N4-NColE7-C* fehérje szekvenciája további aminosavakat tartalmaz az N-terminális végen, a GST-fúziós rész lehasítása miatt, illetve a C-terminális végen, a nem várt mutáció miatt (5.2.2.3. ábra). Az $\mathrm{N}$-terminális rész első-, illetve a $\mathrm{C}$-terminális rész utolsó 9 aminosava nincs jelen a megfejtett szerkezetben, ezeknek a részeknek a rendezetlensége miatt. Az aktív központban egy $\mathrm{Zn}^{2+}$-ion és egy szulfátion elektronsürüsége látható. A kristályosításhoz $0,2 \mathrm{M} \mathrm{Li}_{2} \mathrm{SO}_{4}$ oldatot használtunk, így az NColE7 publikált kristályszerkezeteinek többségében jelenlévő foszfátion helyett itt szulfátion épült be a kristályosítási folyamat alatt. A fehérje hidrofób magjában apoláros 
és aromás oldalláncok jelenléte mutatható ki, míg a felület általában töltött vagy poláros aminosavakkal fedett.

\subsubsection{A colicin E7 nukleáz domén és a $\Delta$ N4-NColE7 szerkezetének összehasonlítása}

A colicin E7 nukláz doménjével (PDB kód: 1M08) hasonlítottuk össze a $\Delta$ N4NColE7-C* fehérje szerkezetét. Elsősorban arra voltunk kiváncsiak, hogy az Nterminális végen megrövidített fehérje megőrzi-e a szerkezetét a pozitív töltésű $\mathrm{R}$ és $\mathrm{K}$ aminosavak elvesztése ellenére. Amint az az 5.3.2.1. ábrán látható a közös aminosavak szuperpozíciója kis $(0,359 \AA)$ rmsd értéket eredményezett, ami a két szerkezet jó egyezésére utal, tehát a $\Delta \mathrm{N} 4-\mathrm{NColE7}-\mathrm{C}^{*}$ nukleáz aktivitása nem egy jelentős konformáció-változás következtében szünt meg. Mindössze a módosult C-terminális részen lévő katalitikus központot nem érintő aminosavak helyzetében figyelhető meg szignifikáns eltérés az NcolE7 fehérjéhez képest.

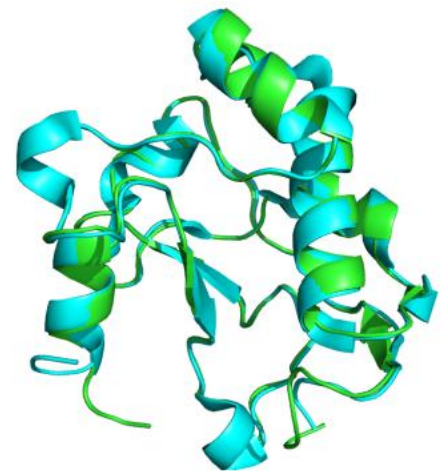

5.3.2.1. ábra: A $\triangle \mathrm{N} 4-\mathrm{NColE7}-\mathrm{C}^{*}$ fehérje szerkezete (zöld), illetve a NColE7 (PDB kód: 1M08) fehérje szerkezete (kék). A két szerkezet jó egyezést mutat, jelentős különbség csak a C-terminális végen látható.

Az aktív központot vizsgálva a két szerkezetben a H573 imidazolgyürü kissé kifordult helyzetében, illetve a hozzá koordinálódó $\mathrm{Zn}^{2+}$-ion helyzetében figyelhető meg különbség (5.3.2.2. ábra). Hasonló jelenség figyelhető meg az inaktív H545 mutáns fehérje aktív központjában, ahol a H544 imidazolgyürüjének kismértékü rotációja látható [55]. E megfigyelés alapján a pozitív töltésü $\mathrm{N}$-terminális aminosavak eltávolítása, bár a fehérje egészének szerkezetét nem változtatja meg szignifikánsan, kihatással van a C-terminális aktív központ fémion körüli szerkezetére. Az 5.2. fejezetben részletezett másik, katalitikus aktivitással nem rendelkező mutánsnál ( $\Delta \mathrm{N} 25$ NColE7), ahol az utolsó 25 N-terminális aminosav került eltávolításra, jelentősen gyengébb fémion és DNS-kötést detektáltunk. Ez a tény szintén alátámaszthatja, hogy 
az N-terminális hurok az aktív központ szerkezetére is befolyással van. Az 5.3.2.2. ábra azt is mutatja, hogy ez az N-terminális hurok, amely nem rendelkezik jól definiált másodlagos szerkezeti elemekkel, szintén megtartja az NColE7-ben kialakított szerkezetet. Ez utóbbi fehérjében kézenfekvő lett volna a hurok megfelelő szerkezetének stabilizálását az N-terminális végen lévő pozitív töltések és a $\mathrm{Zn}^{2+}$-ionhoz kötött negatív töltésű szubsztrát kölcsönhatásának tulajdonítani. A foszfátion az 5.3.2.2. ábrán láthatóan ugyanis hídként köti össze a $\mathrm{Zn}^{2+}$-iont és az R447 aminosavat. A $\Delta \mathrm{N} 4$ NColE7-C* fehérjében azonban a pozitív töltésű N-terminális aminosavak hiánya ellenére az N-terminális hurok az NColE7-ben megfigyelhető szerkezetet vesz fel.

(A)

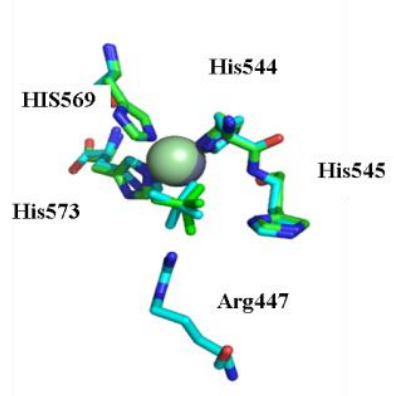

(B)

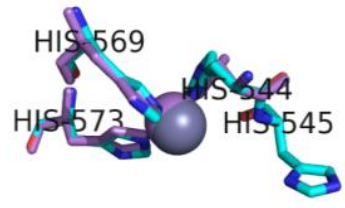

5.3.2.2. ábra: $A$ hisztidin oldalláncok koordinációja a $\mathrm{Zn}^{2+}$-ionhoz a $\triangle \mathrm{N} 4-\mathrm{NColE7}-\mathrm{C}^{*}$, illetve az NColE7 aktív központjában. (A) A $\triangle$ N4-NColE7-C* (zöld) és NColE7 (kék) fehérjék megőrzött hisztidinjeire számított rmsd 0,439 Å. (B) A H545 mutáns (lila) és NColE7 (kék) fehérjék esetében az érték 0,303 Å. A fémiont gömb jelképezi, míg a szulfát/foszfát iont pálcika modellel ábrázoltuk. (Inaktív NColE7 mutáns PDB kód: 2IVH)

Ha viszont nem az utolsó $4 \mathrm{~N}$-terminális aminosav játszik fontos szerepet a két vég egymáshoz közeli szerkezetében, akkor milyen molekulán belüli kölcsönhatások segítik a $\Delta \mathrm{N} 4-\mathrm{NColE7}-\mathrm{C}^{*} \mathrm{~N}$-terminális végén lévő 35 aminosavat tartalmazó hurok megfelelö feltekeredését? Ezen rész szerkezetét és a fehérje többi részéhez viszonyított térbeli helyzetét nem érinti a DNS, illetve az $\operatorname{Im} 7$ fehérje megkötése a különböző NColE7 kristályszerkezetekben. [75,53,55,60,78,77]. Ugyanígy azt is tapasztalhattuk az 5.2. fejezetben, hogy a $\Delta \mathrm{N} 4-\mathrm{NColE7-C} *$ fehérje viszonylag erösen köti a DNS-t. Továbbá a négy N-terminális aminosav törlése nem befolyásolta lényegesen az aktív központ $\mathrm{Zn}^{2+}$-ion affinitását: a $\Delta \mathrm{N} 4-\mathrm{NColE7}-\mathrm{C}^{*}$ fehérje olyan erősen köti a fémiont, hogy a tisztítási folyamatok során az végig kötve marad. 
Megvizsgáltuk tehát az N-terminális hurok aminosavjait érintő kölcsönhatásokat a hidrogénkötések helyzetén keresztül a Hbonds PyMol (Queen's University) program segítségével (5.3.2.3. ábra).
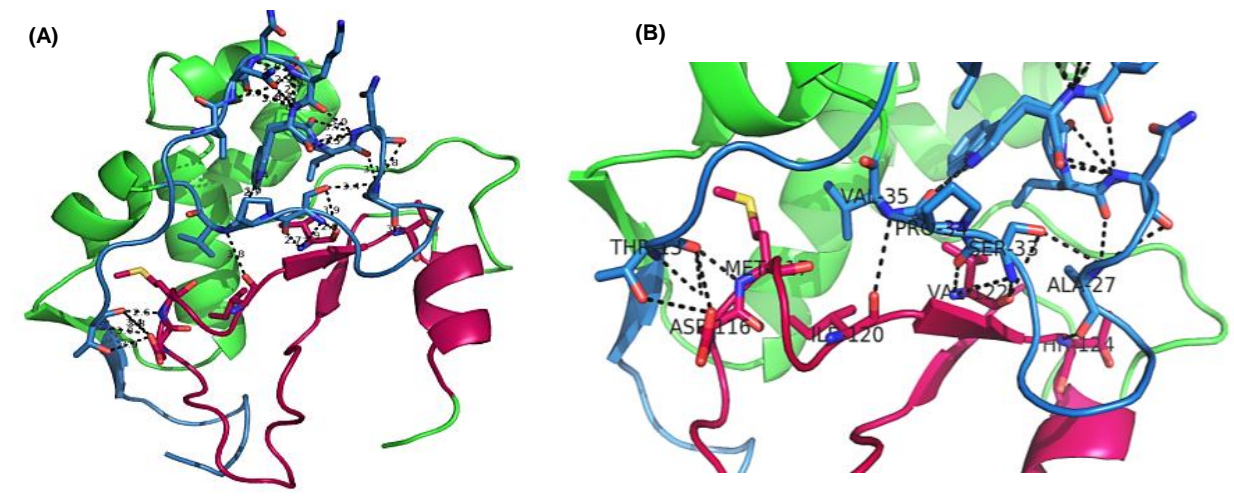

5.3.2.3. ábra: $\triangle \mathrm{N} 4-\mathrm{NColE7}-\mathrm{C}^{*}$ szerkezete. A fehérje $\mathrm{N}$-terminális részét kékkel jelöltük, a $\mathrm{HNH}$ motívumot pedig pirossal. Az N-terminális hurok lehetséges hidrogénkötéseit fekete szaggatott vonalakkal jelöltük (Hbonds).

Látható, hogy az N-terminális hurok térbeli szerkezetének stabilizációja a hidrogénkötések, poláris és hidrofób kölcsönhatások révén valósul meg. A W464 aminosav hidrofób kölcsönhatást alakít ki a közelben lévő hidrofób oldalláncokkal és hidrogénkötéseket az N-terminális hurok aminosavaival (A természetes NColE7 fehérje szerinti számozás alapján). A colicinek és piocinek szekvenciájának összehasonlításakor láthatjuk, hogy W464 a jól megőrzött aminosavak között szerepel, rögzített helyzete fontos szerepet tölthet be az N-terminális hurok szerkezetének kialakításában. Az Nterminális hurok kapcsolatot alakít továbbá ki a HNH motívumban lévő flexibilis hurokkal és az egyik $\beta$ redőjében lévő aminosavakkal. Kölcsönhatások a következő aminosavak között jöhetnek létre: T454-D557, T454-M558, V476-I561, S471-V563, A468-T565 (5.3.2.3. ábra). Fontos megemlíteni, hogy a T454, D557 és V476 jól megőrzött aminosavak. A fentiek alapján nyilvánvaló, hogy az $\mathrm{N}$-terminális hurok jelenléte és kölcsönhatásai stabilizálják a HNH motívum szerkezetét, elősegítve ezzel a $\mathrm{Zn}^{2+}$-ion megkötését és a katalitikus aktivitás kifejtését. A 3.3.3. fejezetben már láthattuk, hogy a HNH motívumban lévő N560 is meghatározó jelentőségü a HNH motívum szerkezetének kialakításában. Ez a szerep a $\Delta$ N4-NColE7-C* mutánsban is megmaradt. Az N560 több hidrogénkötést alakít ki a HNH motívum aminosavjaival stabilizálva a $\mathrm{HNH}$ hurok szerkezetét. Ez biztosítja azt is, hogy az egyik hisztidin oldallánc, bázisként részt vehet a katalitikus folyamatban. Az N560 oldallánc mutációja 
az aktivitás teljes elvesztéséhez vezet [78]. A kiterjedt kölcsönhatások ellenére a magasabb hőmérsékleti faktorokat összehasonlítva a szomszédos fehérje egységgel, a HNH motívum nagy flexibilitását figyelhetjük meg (5.3.2.4. ábra).

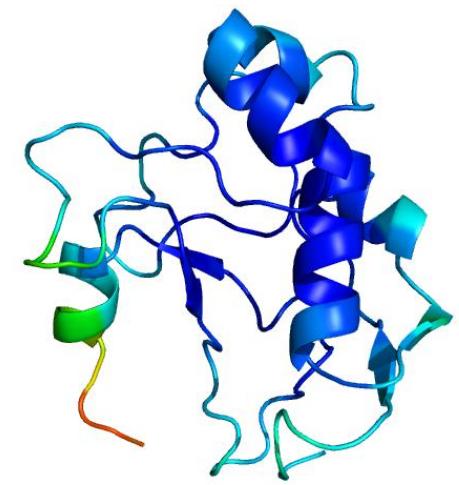

5.3.2.4. ábra: $\triangle N$ N-NColE7-C* fehérje szerkezete a hőmérsékleti faktorok szerint ábrázolva. Nagyobb mértékű flexibiliáts figyelhető meg a végeken. Az N-terminális utolsó aminosavak (piros) különösen mozgékonyak.

\section{Az R447 szerepe}

A colicinek és piocinek szekvenciáinak összehasonlításából az is kiderül, hogy az N-terminális R447 szintén jól megőrzött. Ezek a fehérjék szerkezeti felépítésükben is hasonlóságot mutatnak. Ahol megjelenik a kristályszerkezetben, az R447 közel kerül az aktív központhoz és kölcsönhatást alakít ki a foszfátionnal. (5.3.2.5. ábra).

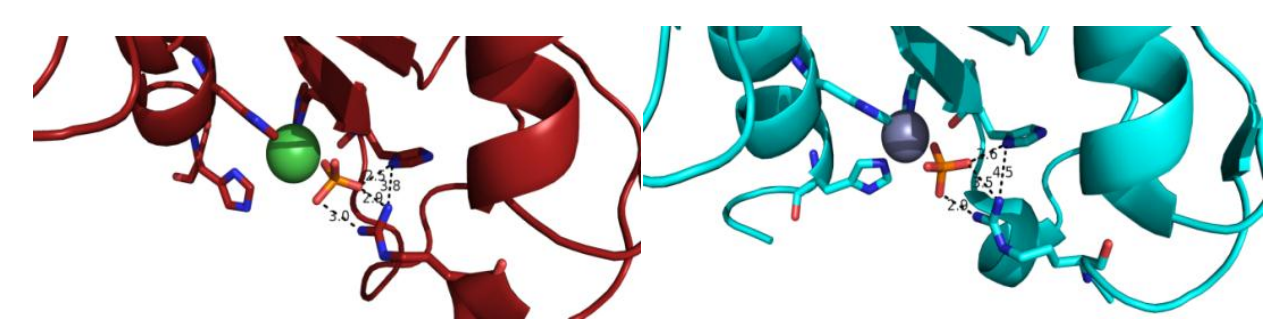

5.3.2.5. ábra: Az N-terminális argining (R447) lehetséges kölcsönhatásai és a ColE9 illetve ColE7 aktív központjában. NColE9 pirossal (1BXI), NColE7 kékkel (1M08). Mindkét kristályszerkezetben látható a fémionhoz koordinálódó foszfátion. $\mathrm{A} \mathrm{Ni}^{2+}$-iont a ColE9 aktív központjában kékkel, míg a $\mathrm{Zn}^{2+}$-iont a ColE7 aktív központjában szürke színnel jelöltük. Az rmsd a két fehérje összehasonlításánál 0,559 Å.

Ezek alapján az R447 arginin szerepe lehet az, hogy megkösse és a megfelelő helyzetben tartsa, valamint elektrosztatikusan aktiválja a DNS hasadó foszfodiészter csoportját. Ez az N-terminális rész stabilitását is maga után vonhatná. Ezzel a feltevéssel ellentétes, hogy a DNS molekulát is tartalmazó kristályszerkezetekben az N- 
terminális aminosavak helyzetét nem tudták meghatározni [53,77,55]. Egyetlen kristályszerkezet esetében látható az N-terminális vég és a DNS, de ebben az esetben a $\mathrm{Zn}^{2+}$-iont távolították el EDTA segítségével a D493Q mutáns fehérjéből [77]. $\mathrm{Zn}^{2+}$-ion hiányában az aktív központ torzult szerkezettel rendelkezik. Az N-terminális arginin az elektrosztatikus kölcsönhatás mellett hidrogénkötéseket is létesít a DNS molekula foszfodiészter csoportjaival, bár túl nagy flexibilitással rendelkezik a hőmérsékleti faktorok alapján (5.3.2.6. ábra).

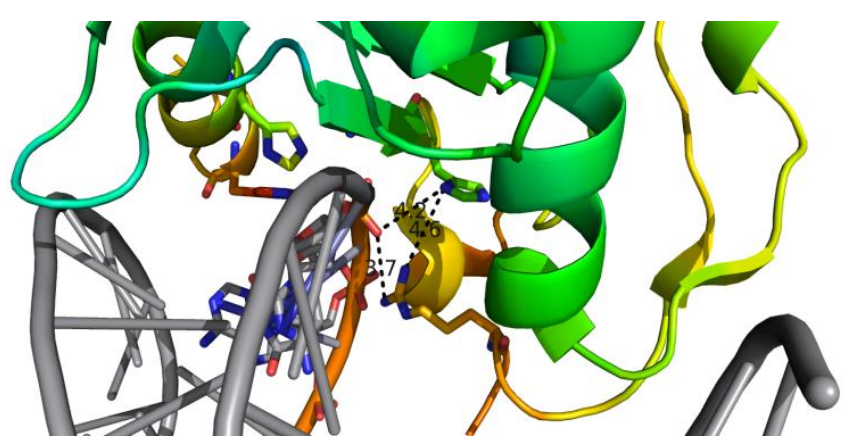

5.3.2.6. ábra: A colicin E7 aktív központjának kristályszerkeze DNS (szürke) jelenlétében, kiemelve az aktív központot $\mathrm{Zn}^{2+}$-ion távollétében (3FBD). A DNS hasadó foszfátcsoportját narancssárgával jelöltük.

A hőmérsékleti faktor értékét többféle paraméter is befolyásolja, mint a kristály minősége, a diffrakciós kép felbontása, mérési zaj, intermolekuláris kölcsönhatások a kristályban. A terminális aminosav oldalláncok általában flexibilisebbek. Habár a hőmérsékleti faktor értéke 60-70 Å az R447 esetében magasnak tekinthető, összehasonlítva a molekula többi részével. Ha ezen aminosav oldallánc szerepe a DNS kötés lenne, úgy azt várnánk, hogy a helyzete sokkal inkább rögzítetté válik DNS jelenlétében. $\mathrm{A}_{\mathrm{Zn}^{2+}}$ és $\mathrm{Ni}^{2+}$-ionok erős koordinatív kötést létesítenek a foszfátionnal, feltehetőleg a DNS hasadó foszfodiészter csoportjának megkötése a központi fémionhoz rendelhető, és az N-terminális argininnek kisebb szerep tulajdonítható.

\section{A távozó csoport protonálása}

A colicin DNáz toxinok müködési mechanizmusának érdekessége, hogy nem ismert, mi szolgál általános savként. Egy vízmolekula vagy valamely aminosav oldallánc felelős a távozó csoport protonálásáért. A ColE9 és E2 esetében az R544, E548 és H575 míg ColE7 esetében az R538, E542 és H569 aminosavak mutációi megszüntetik a nukleáz aktivitást, azaz ezeknek az aminosavaknak jelentős szerep 
tulajdonítható a müködési mechanizmusban. Találunk olyan irodalmat, amely szerint [95,96] ezek az aminosavak protoncsatornát alakíthatnak ki, segítve a távozó csoport protonálódását. Mind az NColE7 kristályszerkezet, mind pedig a $\Delta \mathrm{N} 4-\mathrm{NColE7}-\mathrm{C}^{*}$ szerkezet azt mutatja, hogy a H569 jelentős szerepet játszik a $\mathrm{Zn}^{2+}$-kötésben, illetve ezen aminosav mutációja csökkent $\mathrm{Zn}^{2+}$-kötést és csökkent aktivitást eredményezett (5.3.2.7. ábra).

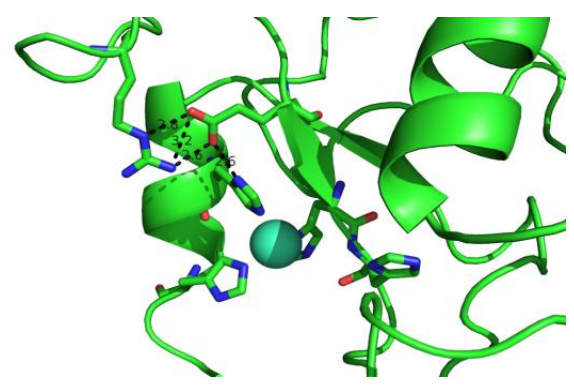

5.3.2.7. ábra: Hidrogénkötések hálózata a $\Delta \mathrm{N} 4-\mathrm{NColE7-C*}$ kristályban az R97, E101 és H128 aminosavak között. A colicin E7 megfelelő aminosavjai rendre: R538, E542, H569.

A fémionhoz koordinálódó imidazol oldallánc kisebb $\mathrm{pK}_{\mathrm{s}}$ értékkel rendelkezik, a protonálódás nem kedvezményezett, és a sztérikus helyzete sem megfelelő a távozó csoport protonálásához. Az E542 hidrogénkötéseket alakít ki a H569, R538 aminosavvakkal rögzítve az E542 helyzetét. Ezeknek az aminosavaknak a szerepe a H569 megfelelő térbeli elhelyezése a fémion-kötéshez. Az R538 a DNS-kötő hurkon helyezkedik el, ennek hiányában a DNS felé hajlás, illetve a foszfodiészter kötés hasadása is kisebb mértékben játszódik le (5.3.2.8. ábra).

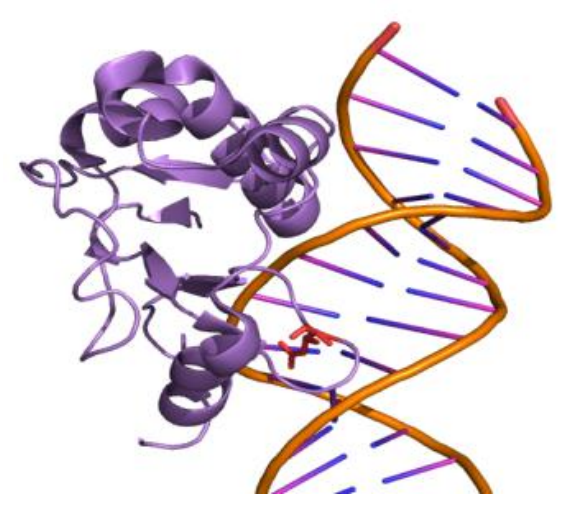

5.3.2.8. ábra: A colicin $E 7$ fehérje nukleáz doménjének DNS kötése $2 I V H$ kristályszerkezet alapján, ahol az R538 aminosav látható piros színnel jelölve. Az ábra jól mutatja a DNS kettős spirál torzulását a fehérjével kialakított kölcsönhatás következményeként. 
Hogy alternatív protoncsatornákat találjunk, az összes lehetséges hidrogénkötést számbavettük a $\triangle \mathrm{N} 4-\mathrm{NColE7}-\mathrm{C}^{*}$ és az NColE7 aktív központjában (5.3.2.9. ábra). Az NColE7 esetében az R447 kapcsolatot alakít ki a foszfátcsoporttal és közel kerül az általános bázis H545 aminosavhoz. Így lehetséges, hogy egy vízmolekula közremüködésével hidrogénkötés létesül közöttük. A $\Delta$ N4-NColE7-C* fehérjében ugyanez a kapcsolat lehetséges lenne, mivel a vízmolekula jelen van, viszont nincs az eltávolított $\mathrm{N}$-terminális Arg. Más protonálható aminosavat, vagy hidrogénion-csatornát nem találtunk az aktív központban.
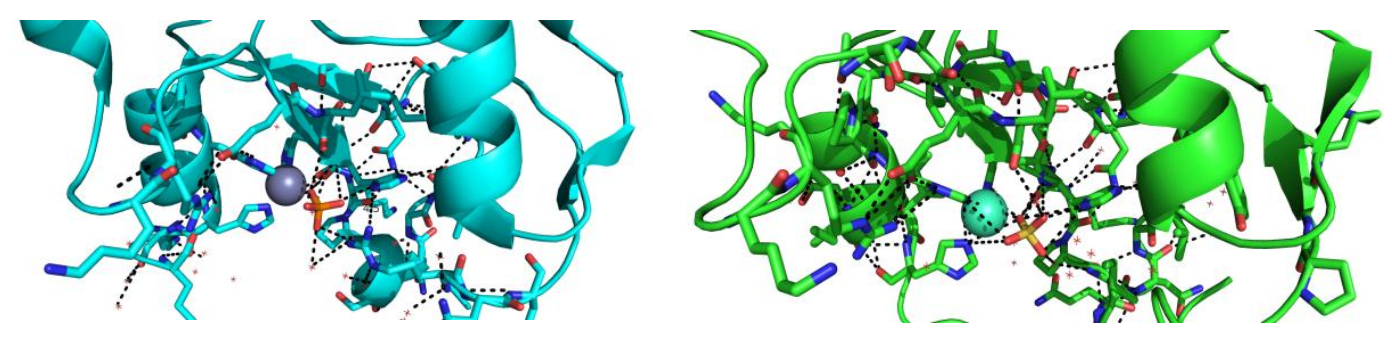

5.3.2.9. ábra: Hidrogénkötések az NColE7 aktív központjában (kék), illetve $\Delta \mathrm{N} 4-\mathrm{NC}$ ColE7-C* fehérjében (zöld). A lehetséges hidrogénkötéseket 3,9 Å-ig jelöltük. Vízmolekulákat piros csillagok reprezentálják. Az ábra a Hbonds PyMol segítségével készült.

\section{Általunk feltételezett mechanizmus}

Ezen eredmények alapján felmerül, hogy az R447 lehet felelős a bázikus távozó csoport protonálásáért. Az Arg oldallánc ezután nagyon gyorsan újraprotonálódhat a protonált H545 aminosavtól protont átvéve a közöttük lévő vízmolekula közremüködésével. H545, mint általános bázis ezután deprotonálja a közelében lévő másik vízmolekulát, majd az így képződött hidroxidion nukleofil támadást hajt végre a parciális pozitív töltéssel rendelkező foszforatomon, és a katalitikus ciklus ismétlődhet. Az R447 tehát egy flexibilis proton-szállító szerepet láthat el a H545 aminosav és a DNS molekula között. Habár az Arg oldalánc ritkán viselkedik savként, biológiai rendszerekben ez a mechanizmus elképzelhető, hiszen a szénhidrát rész 3'alkoholátcsoportja még az argininnél is erősebb bázis. Amint azt a következő fejezetben látni fogjuk, az N-terminális pozitív töltéssel rendelkező oldalláncnak nem szükséges egy rögzített pontban elhelyezkednie a katalitikus aktivitás létrejöttéhez. 


\subsection{3. ${ }^{13} \mathrm{C}$ és ${ }^{15} \mathrm{~N}$ izotópokkal dúsított fehérje előállítása NMR mérések céljából}

A $\triangle$ N4-NColE7-C* fehérje $\mathrm{N}$-terminális végén 8 , nem a természetes szekvenciából származó aminosav jelenlétével kell számolni a GST fúziós rész proteázzal történő lehasítása után. Továbbá, mint azt már említettük, nem várt mutáció lépett fel a C-terminális végen, ahol az utolsó 3 aminosav helyett 12 aminosav épült be (5.2.2.3. ábra). A helyes szekvencia elöállítása, illetve a jövőben tervezett NMR mérések érdekében, GST fúziós rész nélkül próbáltuk meg előállítani a fehérjét. Erre a célra a pET21a vektort választottuk, mivel a klónozó régiójában található restrikciós endonukleáz hasítási helyek a pGEX-6P-1 vektorhoz hasonló elrendezést mutattak. A $\triangle$ N4-NColE7 fehérje génjét az EcoRI, XhoI hasítási helyeket használva ültettük át a pET21a vektorba (F.9. ábra), azonban ezt a fehérjét nem tudtuk kifejzeni, mivel a sejtek már a táptalajon elpusztultak. E klónozás eredményeként 16 N-terminális aminosavval bővült a szekvencia, ahol az ötödik helyen lévő aminosav éppen egy Arg (5.3.3.1. ábra). Ez a természetes NColE7 szekvenciához viszonyítva, két aminosavnyi eltolódást jelent az N-terminális irányba. Így bár nem az NColE7 szekvencia szerint rögzített helyen, de annak közelében lévő Arg elegendőnek bizonyult a nukleáz aktivitás visszanyeréséhez.

\section{MASMTGGQQMGRGSEF PGKATGKGKPVNNKWLNNAGKDLGSPVPDRIANKLRDKEFK $\mathbf{R}^{\star}$ - $\triangle$ N4-NCOIE7 SFDDFRKKFWEEVSKDPELSKQFSRNNNDRMKVGKAPKTRTQDVSGKRTSFELHHEK PISQNGGVYDMDNISVVTPKRHIDIHRGK}

5.3.3.1. ábra: $\triangle \mathrm{N} 4-\mathrm{NColE7}$ fehérje aminosav-szekvenciája a pET21a vektorban az EcoRI/XhoI restrikciós hasítási helyek közé illesztett génszekvencia alapján. A vektor által hordozott szekvencia szürkével jelölve a fehérje N-terminális végéhez füzve. A jelentős szereppel bíró Arg aminosavat ciklámennel jelöltük.

Hasonló citotoxicitást figyeltünk meg akkor, amikor a GST- $\Delta$ N4-NColE7 fehérjét, azaz a C-terminális részen mutációt nem tartalmazó fehérjét próbáltuk meg kifejezni (5.2. fejezet). Ezek alapján valószínüsíthető, hogy a GST fúziós fehérje felületén található számos pozitív töltésű aminosav oldallánc valamelyike hasonlóan 
elősegíti a GST- $\Delta$ N4-NColE7 fehérje nukleáz aktivitását, míg a GST- $\Delta$ N4-NColE7-C** mutánsban ezt a megváltozott C-terminális szekvencia sztérikusan gátolja.

A fenti tapasztalatok alapján a következő kísérletben az NdeI, XhoI hasítási helyek közé klónoztuk be a fehérje génjét, így az 5.3.3.2. ábrán látható, többlet aminosavakat nem tartalmazó $\Delta \mathrm{N} 4-\mathrm{NColE7} *$ fehérjét tudtuk kifejezni. E fehérje már nem mutatott sejtmérgező hatást LB tápoldatban ami alátámasztja, hogy a $\Delta \mathrm{N} 4$ NColE7-C* fehérje GST fúziós rész nélkül nem a C-terminális mutáció miatt inaktív. A fehérjék tisztításának kidolgozásában a korábban GST-fúziós rendszer ioncsere kromatográfiában alkalmazott körülményei szolgáltak kiindulási alapul, hiszen ott már a fúziós résztől megszabadított, hasonló fehérjeszekvenciákat tisztítottuk. Így a fehérjét első lépésben egy Sepharose Fast Flow ioncserélő oszlopon (5.3.3.3. ábra), majd a GST-fúziós rendszer második lépéseként is alkalmazott Source $30 \mathrm{~S}$ kolonnán tisztítottuk meg (5.3.3.4. ábra).
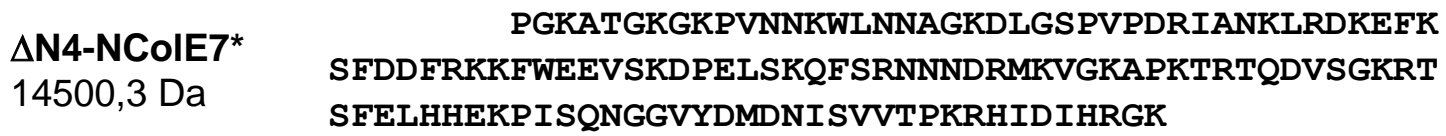

5.3.3.2. ábra: $\triangle \mathrm{N} 4-\mathrm{NColE7} *$ fehérje szekvenciája többlet aminosavak nélkül.

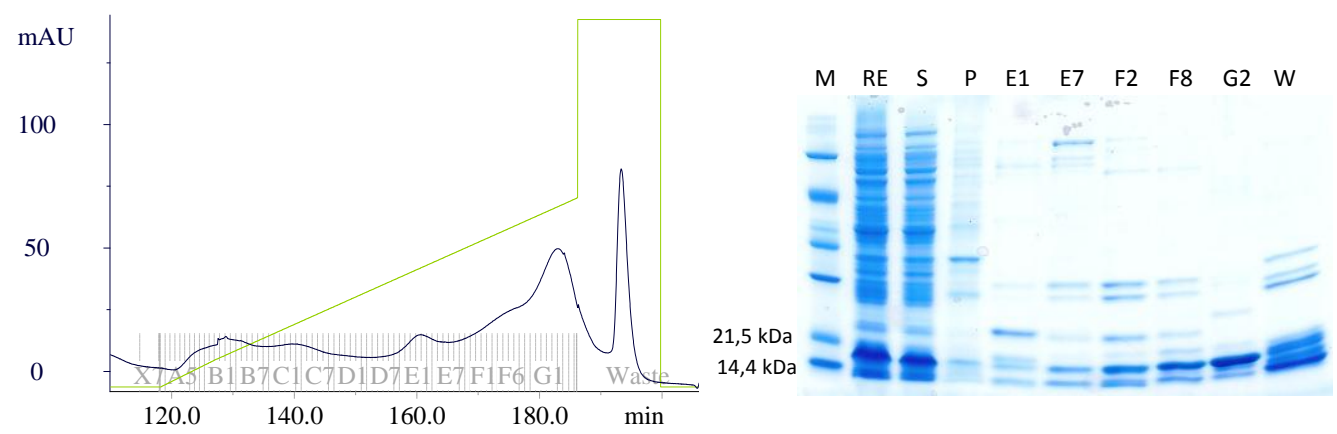

5.3.3.3. ábra: $\triangle \mathrm{N} 4-\mathrm{NC}$ ColE7* fehérje tisztítása HPLC eljárással Sepharose Fast Flow ioncsere oszlopon. Az ábrán a kromatogram részlete látható. Zöld vonallal az eluciós oldat gradiensét jelöltük. Az eluált frakciókhoz tartozó gélelektroforézis képe jobb oldalon látható $\left(\mathrm{M}_{\mathrm{r}}=14,5 \mathrm{kDa}\right)$. Az E7-G2 frakciókat gyüjtöttük és második lépésben tovább tisztítottuk. 

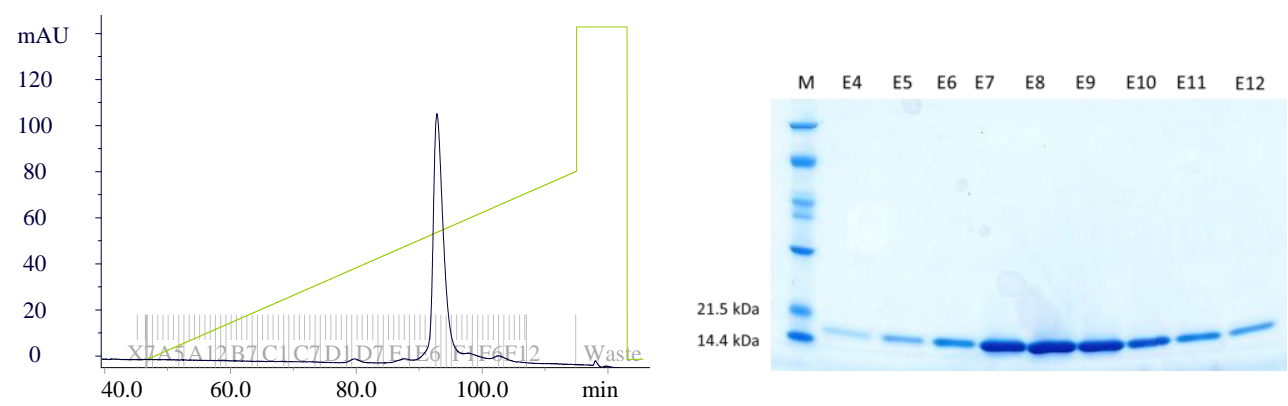

5.3.3.4. ábra: $\triangle \mathrm{N} 4-\mathrm{NColE7} 7^{*}$ fehérje tisztítása HPLC-s eljárással Source $30 \mathrm{~S}$ ioncsere oszlopon. Az ábrán a gradiens elúcióhoz tartozó (zöld vonal) kromatogram részlete látható, illetve az eluált frakciókhoz tartozó gélelektroforézis képe $\left(\mathrm{M}_{\mathrm{r}}=14,5 \mathrm{kDa}\right)$.

A későbbi NMR mérések olyan ún. minimál-tápoldatban (M9 összetétel: F.2. táblázat) történő fehérjekifejezést igényelnek, mely elkészítéséhez ${ }^{15} \mathrm{~N}$, és ${ }^{13} \mathrm{C}$-tartalmú vegyületek szükségesek. Ebbe a tápoldatba nem tettünk $\mathrm{Zn}^{2+}$, vagy egyéb fémiont, így a baktérium azt nem is tudta beépíteni a képződő fehérjébe. A $\Delta$ N4-NColE7* tömegspektrometriás mérése is alátámasztotta a fehérje tisztaságát, illetve azt, hogy a tisztított fehérje fémion nélküli formában van jelen. Ugyanezt a fehérjét LB tápoldatban növesztett sejtekben is kifejeztük. Mivel itt lehetőség volt $\mathrm{Zn}^{2+}$-ion felvételére a fehérjét $\mathrm{Zn}^{2+}$-komplexe formájában sikerült kinyernünk (5.3.3.5. ábra). Amennyiben az M9 tápoldatból kifejezett és tisztított $\triangle \mathrm{N} 4-\mathrm{NColE7} *$ oldatához egy ekvivalensnyi $\mathrm{Zn}^{2+}$-iont adtunk, a $\mathrm{Zn}^{2+}$-komplexnek megfelelő molekulatömeget nyertünk az MS mérésekből.

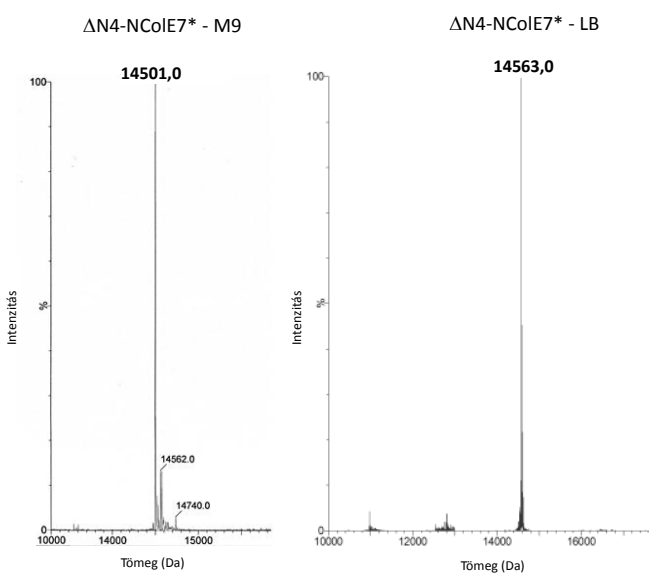

5.3.3.5. ábra: $\triangle \mathrm{N} 4-\mathrm{NColE7} 7$ fehérje $\mathrm{M} 9$ és LB tápoldatból történt tisztításának tömegspektrumai. Az M9 minimál tápoldathoz nem adtunk fémiont, így a tisztított fehérje nem tartalmazott fémiont (a számított molekulatömeg $\left.\mathrm{M}_{\mathrm{r}}=14500,3 \mathrm{Da}\right)$. Az LB tápoldatból megtisztított $\Delta \mathrm{N} 4-\mathrm{NColE7} *$ fehérje $\mathrm{Zn}^{2+}$ komplexeként detektálható, amelynek számított molekulatömege: $\mathrm{M}_{\mathrm{r}}=14565,3 \mathrm{Da}$. 
Ezek alapján valóban az M9 tápoldat összetételéből adódott a fémion hiánya a tisztított fehérjében. Ugyanakkor érdemes itt megjegyezni, hogy az 5.2. és 5.3.1. fejezetekben vizsgált C-terminális mutációt tartalmazó fehérje $\left(\triangle \mathrm{N} 4-\mathrm{NColE} 7-\mathrm{C}^{*}\right) \mathrm{Zn}^{2+}$. kötésében nem mutatott számotevő különbséget a $\triangle \mathrm{N} 4-\mathrm{NColE7} 7$ fehérjéhez képest. Ez arra utal, hogy a C-terminális mutációnak nem volt lényeges hatása a fémionnal kialakított kölcsönhatásra.

A $\triangle \mathrm{N} 4-\mathrm{NColE7*}$ M9 minimál tápoldatból történő kifejezésének és tisztításának optimalizálása után e folyamatokat ${ }^{13} \mathrm{C}^{*}$ és ${ }^{15} \mathrm{~N}^{*}$ tartalmú tápoldatból (M9*) is megismételtük NMR mérésekre alkalmas fehérje előállítása céljából. Így 2,7 mg ${ }^{13} \mathrm{C},{ }^{15} \mathrm{~N}-\Delta \mathrm{N} 4-\mathrm{NColE} 7 *$ fehérjét sikerült tisztítani $500 \mathrm{ml}$ jelzett M9* tápoldatból.

Az első ${ }^{15} \mathrm{~N}$-HSQC NMR mérések $\mathrm{Zn}^{2+}$-ion hiányában és jelenlétében (5.3.3.6. ábra) jó egyezést mutattak, ami már a $\mathrm{Zn}^{2+}$-ion megkötése előtt is rendezett szerkezet kialakulására enged következtetni. Ez szintén az N-terminális hurok szerkezetstabilizáló hatását, illetve a fehérje két vége közötti kölcsönhatást támasztja alá. Ahhoz, hogy pontosabb következtetéseket tudjunk levonni, az NMR spektrumokban bekövetkezett változásokról a jelek hozzárendelésére van szükség, amit a jövőbeni kutatásaink során tervezünk megvalósítani.

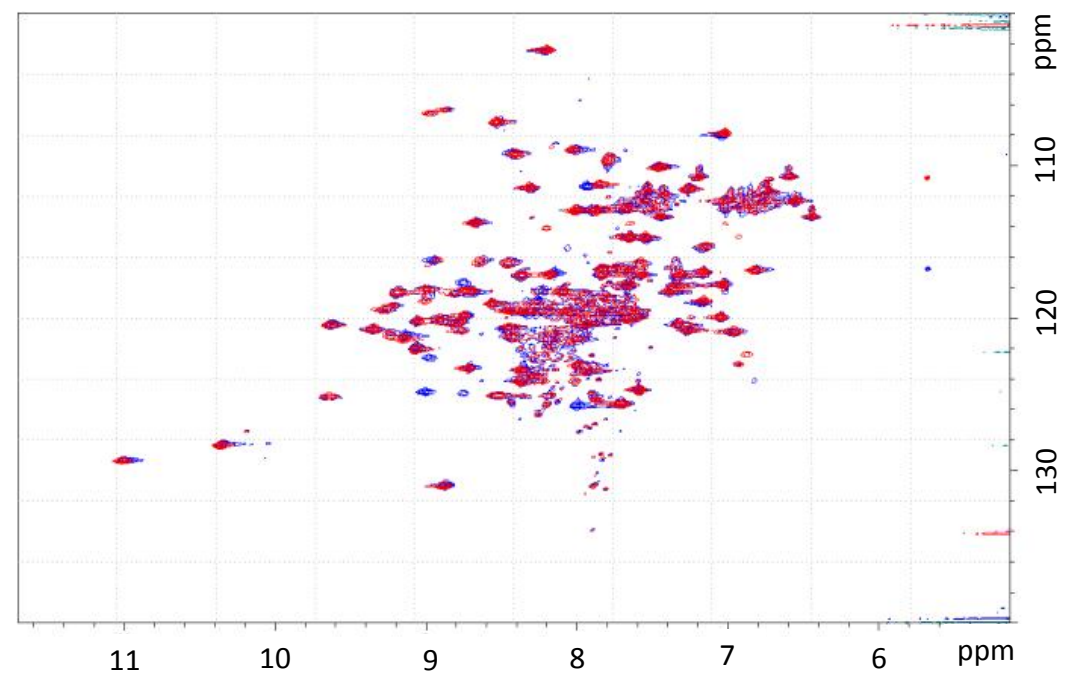

5.3.3.6. ábra: $\mathrm{A}^{13} \mathrm{C},{ }^{15} \mathrm{~N}-\Delta \mathrm{N} 4-\mathrm{NColE} 7 *$ jelzett fehérje ${ }^{15} \mathrm{~N}-\mathrm{HSQC}$ NMR spektruma $\mathrm{Zn}^{2+}$-ion hiányában (piros) és jelenlétében (kék). 


\subsubsection{Eredmények és tárgyalásuk}

A $\triangle \mathrm{N} 4-\mathrm{NColE7-C} *$ és az NColE7 (1M08) kristályszerkezetének összehasonlítása jó egyezést mutat (5.3.2.1. ábra) ami arra utal, hogy a négy $\mathrm{N}$ terminális aminosav eltávolítása nem okoz jelentős konformáció-változást, azaz az aktivitás megszünése nem ennek következménye. Látható az is, hogy a jól definiált másodlagos szerkezeti egységekkel nem rendelkező N-terminális hurok megtartja helyzetét a mutáció ellenére is, ami azt jelenti, hogy nem a pozitív töltésü aminosavak játszanak szerepet szerkezetének stabilizálásában. A kristályszerkezetből látható, hogy az N-terminális hurok a C-terminális HNH motívummal összetett hidrogénkötés hálózatot alakíti ki (5.3.2.3. ábra), melyen keresztül az N-terminális hurok hozzájárul a HNH motívum szerkezetének kialakításához, a $\mathrm{Zn}^{2+}$-kötéshez. Ezt támasztja alá a 5.2. fejezetben vizsgált rövidebb mutáns ( $\triangle \mathrm{N} 25-\mathrm{NColE7}),-$ amelyben ez az $\mathrm{N}$-terminális hurok hiányzik - gyengébb $\mathrm{Zn}^{2+}$ és DNS-kötése is.

Az eltávolított N-terminális R447 arginin aktív központhoz közeli helyzete feltételezésünk szerint, nem pusztán a DNS kötés következménye. Ez a kölcsönhatás ugyanis rögzítené az arginin oldalláncot. Ugyanakkor megfigyelhető, hogy a rendelkezésünkre álló NColE7 a kristályszerkezetek többségében ennek az aminosavnak a helyzete nem határozható meg túl nagy flexibilitása miatt. Ezen tulajdonsága révén viszont, mozgékony protonforrásként, a távozó csoportot protonálhatja, azaz általános savként viselkedhet. A közelében lévő, az első lépésben általános bázisként funkcionáló protonált H545 lehet felelős a leadott proton gyors pótlásáért. E javasolt mechanizmus alátámasztására további NMR vizsgálatokat terveztünk. Az előzetes NMR mérések a $\triangle \mathrm{N} 4-\mathrm{NColE7}$ fehérje szerkezetének stabilitását igazolják, mind $\mathrm{Zn}^{2+}$-ion hiányában, mind jelenlétében (5.3.3.6. ábra). Bár $\mathrm{Zn}^{2+}$-ionok hozzáadására a szerkezetben kismértékű változások detektálhatók, a rendezett szerkezet már enélkül is kialakul, ami szintén alátámasztja az N-, és a C-terminális végek közötti kölcsönhatások jelentőségét. 


\section{6. Összefoglalás}

Kutatócsoportunk távlati célja egy szabályozott módon müködő mesterséges metallonukleáz tervezése genetikai alkalmazásokhoz. PhD munkám során e kutatások első fázisába kapcsolódtam be. Széleskörü irodalmazási folyamat következményeként tanulmányaink célpontjául a colicin E7 bakteriális toxint, illetve ennek nulkeáz doménjét (NColE7) választottuk. Elsőként e fehérje C-terminális végén található, az evolúció során jól megőrződött, $\mathrm{Zn}^{2+}$-ion jelenlétében stabilizálódó HNH motívummal mint nukleáz aktivitásért felelős fehérjerészlettel - foglalkoztam. A 42 aminosavból álló motívum előállítása kihívást jelentett, ugyanis megbízható szilárd fázisú peptidszintézishez mérete már túlságosan nagy, míg a rekombináns DNS technológiában kicsiny fehérjének számít. Amint az kísérleteink során be is igazolódott, az E. coli sejtek e fehérjét lebontották. Ezért a HNH motívumot kerülö úton, ubikvitin-fúziós fehérjeként állítottuk elö, több lépésben tisztítva. A tömegspektrometriás mérések alapján a tisztított fehérje nem tartalmazott $\mathrm{Zn}^{2+}$-iont, és a fémion hozzáadására is csak gyenge kölcsönhatást tapasztaltunk: a fémion nagy feleslege mellett sem volt képes azt kvantitatívan megkötni. A cirkuláris dikroizmus spektroszkópiás vizsgálatok alapján megállapítottuk, hogy a HNH motívum - publikált kristályszerkezetek alapján - várt szerkezete vizes oldatban csak részben alakul ki, amit a fémion koordinációja segít. A HNH motívum nem rendelkezik detektálható DNS-kötő képességgel, illetve nukleáz aktivitással.

A nukleáz aktivitásért felelős minimális fehérjerészlet keresése érdekében 4 különböző - N terminális végen rövidített - NColE7 mutánst állítottunk elő. A $\Delta$ N69-, $\Delta \mathrm{N} 45-, \Delta \mathrm{N} 25-$, és $\Delta \mathrm{N} 4-\mathrm{NColE7}$ mutánsok ( $\Delta \mathrm{NX}$-ben az X a 446-576 NColE7 fehérje $\mathrm{N}$-terminális szekvenciájából hiányzó aminosavak számát mutatja) mind kifejezhetőek baktériumsejtekben, azaz nem rendelkeznek sejtmérgező hatással, mint a természetes szekvenciájú NColE7, melynek génjéről a legtöbb vektorban a fehérjetermelés indukálása nélkül is minimális mértékben kifejeződő fehérje elpusztítja a transzformált baktériumokat. Ennek megfelelően a teljes nukleáz doménnel citotoxikus aktivitást tapasztaltunk. Ez arra utal, hogy az NColE7 C-terminális katalitikus egységének müködőképességéhez mindenképpen szükséges az N-terminális végen megtalálható pozitív töltésü oldallánccal rendelkező aminosavakban gazdag részlet. Az irodalomban már közölt kristályszerkezetek közül néhányban meg is található egy olyan arginin aminosav (R447), mely az aktív központ közelében helyezkedik el, és a szubsztrát- 
molekula hasadó foszfodiészter kötése hídként köti össze a HNH motívumban kötött $\mathrm{Zn}^{2+}$-ionnal. Ez a jelenség egy allosztérikus aktiválás lehetőségét veti fel. Ezért a továbbiakban az $\mathrm{N}$-terminális részek szerepének tisztázása érdekében a $\triangle \mathrm{N} 4-\mathrm{NColE} 7$ és $\Delta \mathrm{N} 25-\mathrm{NColE7}$ mutánsok tulajdonságait vizsgáltuk részletesebben. A $\Delta \mathrm{N} 4-\mathrm{NColE} 7$ mutáns génje a pGEX-6P-1 vektorba ligálva (GST-fúziós fehérjeként kifejezve) a természetes NColE7-hez hasonlóan mérgezőnek bizonyult, így a baktériumsejtekből egy C-terminális módosítással sikerült azt izolálni. Mivel ez a módosítás fehérje funkciója szempontjából lényeges aminosavakat nem érintette, ezzel a fehérjével a (GST fúziós rész eltávolítása után) $\Delta$ N4-NColE7-C* néven foglalkoztunk tovább. A tisztítási lépések során ez a fehérje megtartotta a kifejezés során megkötött $\mathrm{Zn}^{2+}$-iont, míg a $\Delta \mathrm{N} 25-\mathrm{NColE} 7$ fehérjét fémion nélkül detektáltuk, és nagy fémion-felesleg mellett is csak részben alakult ki a $\mathrm{Zn}^{2+}$-fehérje komplex. A cirkuláris dikroizmus spektroszkópiás mérések során a $\Delta \mathrm{N} 25-\mathrm{NColE7}$ mutáns oldatának spektrumai a $\mathrm{Zn}^{2+}$ ion adagolásának hatására folyamatos változást mutatnak, míg a $\Delta$ N4-NColE7-C* szerkezete nem változott lényegesen a fémion koordinációjának hatására, azaz a katalitikus központ szerkezetét az N-terminális végen jelenlévő hurok részlet stabilizálta. Továbbá a $\Delta \mathrm{N} 25-\mathrm{NColE7}$ mutáns sokkal gyengébb DNS-kötést mutatott, mint a $\Delta \mathrm{N} 4-\mathrm{NColE7-C} *$ fehérje. Az N-terminális hurok eltávolítása tehát, mind a $\mathrm{Zn}^{2+}{ }_{-}$, mind pedig a DNS-kötés mértékét jelentősen csökkentették, ami az eltávolított rész fontos szerepére utal.

A $\Delta$ N4-NColE7-C* mutáns annak ellenére sem képes a DNS kétszálú hasítására, hogy mind a $\mathrm{Zn}^{2+}$-iont, mind a DNS molekulát erősen köti. Annak megválaszolására, hogy a nukleáz aktivitás elvesztése pontosan milyen összefüggésben van az utolsó 4 aminosav hiányával, a $\Delta$ N4-NColE7-C* térszerkezetének meghatározását tüztük ki célul. A nagymennyiségü tiszta fehérjéből sikerült egykristályt növesztenünk, mely alkalmas volt röntgen-diffrakciós mérések elvégzésére 1,6 $\AA$ felbontással. A fehérje szerkezetének részletes vizsgálata igazolta, hogy a jól definiált másodlagos szerkezeti elemekkel nem rendelkező N-terminális hurok aminosavjainak helyzete megegyezik az NColE7 fehérjében tapasztaltakkal. Ez annyit jelent, hogy e hurok helyzetét nem az N-terminális pozitív töltésü aminosavak kölcsönhatásai határozzák meg.

A szerkezetből az is kiderült, hogy az N-, és C-terminális vég között e mutáns fehérjében is kialakul egy hidrogénkötés hálózat, amelyen keresztül az N-terminális vég 
hozzájárul a C-terminális aktív központ szerkezetének stabilitásához. Ez a megfigyelés megmagyarázza a $\Delta \mathrm{N} 25-\mathrm{NColE} 7$ mutáns C-terminális aktív központjának gyengébb $\mathrm{Zn}^{2+}$-kötését, rendezetlenebb szerkezetét. A rövidebb mutáns fehérje gyengébb DNSkötésének oka szintén a szerkezeti instabilitásban keresendő, hiszen az irodalmi adatokból tudjuk, hogy az NColE7 fehérje szerkezete nem változik meg DNS kötés hatására, azaz a rendezett szerkezet alkalmas a DNS molekula megkötésére is.

A mutáns fehérjéknél hiányzó pozitív töltésű R447 Arg aminosav jelenléte a fentiek ellenére szükséges a nukleáz aktivitáshoz. Az eddig ismert kristályszerkezetek alapján - mivel helyzete a legtöbb esetben nem határozható meg egyértelmüen feltehetőleg flexibilis általános savként a távozó csoport protonálását végzi. Bár az arginin meglehetősen bázikus tulajdonságú, biológiai környezetben a deprotonált 3'hidroxilcsoportnak átadott protonját könnyen visszanyerheti közvetlenül, vagy egy vízmolekulán keresztül közvetett úton az első lépésben bázisként viselkedő, protonált hisztidin-oldalláncról. Ezen hipotézis igazolására a jövőben további NMR méréseket tervezünk.

A fentiek alapján az NColE7 képezheti egy pozitív allosztérikus szabályozás alatt működő, biztonságos mesterséges metallonukleáz alapját. 


\section{Summary}

The aim of our research group is to design a well-controlled, artificial metallonuclease for genetic purpuse. I joined this research project at its early stage. As a result of reviewing the related papers, the nuclease domain of colicin E7 bacterial toxin (NColE7) have been chosen as the target of our research. First I have performed the examination of the C-terminal sequence of the colicin E7 protein, which is responsible for nuclease activity containing a well conserved $\mathrm{HNH}$ motif stabilized by the presence of $\mathrm{Zn}^{2+}$-ion. The production of these 42 amino acids long protein was a challenge, since it is too big for the solid phase peptide synthesis and too small for the recombinant DNA technology. Indeed, based on our first experiences, this protein has been degraded by the $E$. coli cells so we expressed it as the ubiquitin fusion protein. It was purified in few chromatographic steps. According to the mass spectrometric measurements the purified protein did not contain $\mathrm{Zn}^{2+}$-ion. On addition of metal ion in an excessive amount, weak interaction was detected but no quantitative binding was observed. Circular dichroism (CD) spectroscopy provided information about the structure of the HNH motif. From these measurements we concluded that the formation of the structure - close to that predicted from the available NColE7 crystal structure - was supported by the coordination of the metal ion. Neither nuclease activity nor DNA binding ability of the HNH motif was detected.

To determine the minimal sequence responsible for the nuclease activity, four different N-terminally truncated NColE7 mutants were expressed: $\Delta \mathrm{N} 69-, \Delta \mathrm{N} 45-$, $\Delta \mathrm{N} 25-, \Delta \mathrm{N} 4-\mathrm{NColE7}$ protein $(\mathrm{X}$ in $\triangle \mathrm{NX}-\mathrm{NColE7}$ represents the missing amino acids at the N-terminus of the 446-576 NColE7). All mutants can be expressed in E.coli cells, which proves the lack of their nuclease activity, while even one molecule of the wild type enzyme - expressed without the induction of protein production - is able to kill the cell. Only the whole nuclease domain exposed citotoxic activity, which refers to the fact that the N-terminal positively charged residues are necessary for the function of the $\mathrm{C}$ terminal catalytic unit. In a few among crystal structures of NColE7 published in the literature, the N-terminal R447 residue has been found in the proximity of the Cterminal acitve centre bridging the scissile phosphate of the substrate and the $\mathrm{Zn}^{2+}$-ion of the HNH motif. This phenomenon suggests the possibility of an allosteric activation of the catalytic centre. Further examinations were carried out with $\triangle \mathrm{N} 4-\mathrm{NColE} 7, \Delta \mathrm{N} 25$ NColE7 mutants to get deeper insight into the role of the $\mathrm{N}$-terminal amino acids. The 
gene of the $\triangle \mathrm{N} 4-\mathrm{NColE7}$ mutant ligated into the pGEX-6P1 vector (expressed as GSTfusion protein) had cytotoxic activity, just like the native NColE7. Therefore, a protein with a C-terminal modification was identified. Since none of the functional residue have been affected by this additional mutation (after the cleavage of the GST fusion part) $\triangle \mathrm{N} 4-\mathrm{NColE7}-\mathrm{C}^{*}$ was examined. This mutant was able to retain $\mathrm{Zn}^{2+}$-ion during the whole purification process, while $\Delta \mathrm{N} 25-\mathrm{NColE} 7$ was detected without the metal ion. Not even in the presence of an excess of $\mathrm{Zn}^{2+}$-ions the $\mathrm{Zn}^{2+}$-protein complex was quantitively formed. Small changes were observed in the circular dichroism (CD) spectra of the $\triangle \mathrm{N} 25-\mathrm{NColE} 7$ when we added $\mathrm{Zn}^{2+}$-ion to the protein, while the $\mathrm{Zn}^{2+}$-ion did not cause significant structural changes in the $\Delta \mathrm{N} 4-\mathrm{NColE7}-\mathrm{C}^{*}$ mutant. This suggests that the $\mathrm{N}$-terminal loop has a structure stabilization effect on the C-terminal catalytic centre. Furthermore, the $\Delta \mathrm{N} 25$-NColE7 mutant showed much weaker DNA binding affinity than the $\Delta \mathrm{N} 4-\mathrm{NColE7}-\mathrm{C}^{*}$ mutant. Thus, removal of the $\mathrm{N}$-terminal loop of the protein decreased the $\mathrm{Zn}^{2+}$ and DNA-binding ability, which points to the importance of this structural element.

The $\triangle$ N4-NColE7-C* mutant is not able to cleave the DNA, despite the fact that it is capable of binding both the $\mathrm{Zn}^{2+}$-ion and the double stranded DNA. 3D-structure determination of this protein may provide information about how the removal of the four $\mathrm{N}$-terminal amino acids is related to the missing nuclease activity. A protein single crystal was grown from the purified protein, and X-ray diffraction measurements were carried out up to a resolution of $1.6 \AA$. The structure determination of this protein proved that the steric arrangement of the flexible N-terminal loop - missing secondarystructure elements - is the same as in the strucure of NColE7 native enzyme. That is the position of the $\mathrm{N}$-terminal loop is not determined by the interaction of the $\mathrm{N}$-terminal positively charged amino acids with the substrate or its analogue. According to the determined structure of the mutant protein, an extensive hydrogen bond network is formed between the C-, and the N-termini, which stabilizes the structure of the Cterminal active centre. This observation explains the weaker $\mathrm{Zn}^{2+}$-binding ability of the $\triangle \mathrm{N} 25-\mathrm{NColE7}$ mutant based on the less organised structure of its $\mathrm{C}$-terminal active centre. The reason of the weaker DNA binding ability of this protein lies also in the strucutre instability, hence based on the literature the protein conformation does not change when NColE7 binds to DNA, i.e. the well organised structure is capable of strong DNA binding. Despite the above mentioned information the presence of the 
positively charged amino acids - missing from the mutant proteins - is necessary for the nuclease activity. Based on the published crystal structures, where the determination of the N-terminal Arg residue was not succesfull in most cases, its role as a general acid may be the protonation the leaving group, due its flexibility. Although, arginine is generally a basic residue, in biological systems it may donate its proton to the deprotonated 3'-hydroxy group. The lost proton can be recovered either directly or in an indirect way through a water molecule from the protonated His residue, which behaved as a general base in the first step of the cleavage reaction. In order to prove this hypothesis, further NMR measurments will be carried out.

Based on the above collected information, the NColE7 protein may become a platform of a safe, artificial metallonuclease, which is able to work under positive allosteric control. 


\section{Rövidítések jegyzéke}

EcoRI, BamHI, XhoI, FokI, stb

RNáz

DNáz

NColE7

Im

BtuB

cea, cei, cel

IPTG

GST

SDS-PAGE

PCR

CD

SRCD

MS

bp

rpm

amp

pCG1

LB

kan

DH10B, Mach 1,

XL10 Gold,

BL21(DE3)

ColE7

HNH motívum
A DNS hasítását végző bakteriális eredetü specifikus szekvenciát felismerő restrikciós endonukleázok jelölése

RNS molekula hasítását végző fehérje

DNS molekula hasítását végző fehérje

colicin E7 fehérje nukleázdoménje

A colicinek immunitás-fehérjeinek jelölése

Sejtfelszíni receptor

Gének jelölései

izopropil- $\beta$-D-1-tiogalaktozid

Glutation-S-transzferáz

Sodium Dodecyl Sulfate Polyacrylamide Gel Electrophoresis

Polymerase Chain Reaction - Polimeráz láncreakció

Cirkuláris Dikroizmus

Synchrotron Radiation Circular Dichroism

Mass Spectromety

bázispár

round per minute - fordulat/perc

ampicillin antibiotikum

specifikus szekvenciát felismerő proteáz

Luria Broth típusú baktériumok tenyésztésére szolgáló közeg

kanamicin antibiotikum

E. coli törzs

E. coli törzs

E. coli törzs

colicin E7 fehérje, amelyet baktériumok állítanak elő saját védelmükre Hisztidin, aszparagin, hisztidin aminosavakat meghatározott sorrendben tartalmazó, jól megőrzött 42 aminosavból álló szerkezeti egység 


\section{Hivatkozott közlemények jegyzéke}

[1] B. Gyurcsik, A. Czene: Towards artificial metallonucleases for gene therapy: recent advances and new perspectives. Future Med. Chem., 3, 1935-1966 (2011)

[2] Jolly CJ, Cook JLA, Manis JP: Fixing DNA breaks during class switch recombination. JEM. 205, 509-513 (2008).

[3] Raynard S, Niu H, Sung P: DNA double-strand break processing: the beginning of the end. Genes Dev. 22, 2903-2907 (2008).

[4] Shrivastav M, De Haro LP, Nickoloff JA: Regulation of DNA double-strand break repair pathway choice. Cell Res. 18, 134-147 (2008).

[5] Jackson SP, Bartek J: The DNA-damage response in human biology and disease, Nature 461, 1071-1078 (2009).

[6] Niu H, Raynard S, Sung P: Multiplicity of DNA end resection machineries in chromosome break repair. Genes Develop. 23, 1481-1486 (2009).

[7] Pontier DB, Tijsterman M: A robust network of double-strand break repair pathways governs genome integrity during C. elegans development. Curr. Biol. 19, 1384-1388 (2009).

[8] Takashima Y, Sakuraba M, Koizumi T, Sakamoto H, Hayashi M, Honma M:

Dependence of DNA double-strand break repair pathways on cell cycle phase in human lymphoblastoid cells. Environ. Mol. Mutagenesis 50, 815-822 (2009).

[9] Mimitou EP, Symington LS: DNA end resection: many nucleases make light work. DNA Repair 8, 983-995 (2009).

[10] Costanzo V, Chaudhuri J, Fung JC, Moran JV: Dealing with dangerous accidents: DNA double-strand breaks take centre stage. EMBO Reports 10, 837-842 (2009).

[11] Rowe BP, Glazer PM: Emergence of rationally designed therapeutic strategies for breast cancer targeting DNA repair mechanisms. Breast Cancer Res. 12:203 (2010).

[12] Lieber MR: The mechanism of human nonhomologous DNA end joining. J. Biol. Chem. 283, 1-5 (2008).

[13] Lieber MR, Lu H, Gu J, Schwarz K: Flexibility in the order of action and in the enzymology of the nuclease, polymerases, and ligase of vertebrate non-homologous DNA end joining: relevance to cancer, aging, and the immune system. Cell Res. 18, 125-133 (2008).

[14] Bibikova M, Carroll D, Segall DJ et al.: Stimulation of homologous recombination through targeted cleavage by chimeric nucleases. Mol. Cell. Biol. 21, 289-297 (2001).

[15] Sung P, Klein H: Mechanism of homologous recombination: mediators and helicases take on regulatoy functions. Nature Rev. Mol. Cell Biol. 7, 739-750 (2006).

[16] Mimitou EP, Symington LS: Nucleases and helicases take center stage in homologous recombination. Trends Biochem. Sci. 34, 264-272 (2009).

[17] Lieberman-Lazarovich M, Levy AA: Homologous recombination in plants: an antireview. Methods Mol. Biol. 701, 51-65 (2011).

[18] Sharan SK, Thomason LC, Kuznetsov SG, Court DL: Recombineering: a homologous recombination-based method of genetic engineering. Nature Protoc. 4, 206-223 (2009).

[19] Pingoud A, Silva GH: Precision genome surgery. Nature Biotechnol. 25, 743-744 (2007). 
[20] Harris KL, Lim S, Franklin SJ: Of folding and function: Understanding active-site context through metalloenzyme design. Inorg. Chem. 45, 10002-10012 (2006).

[21] Park HS, Nam SH, Lee JK et al.: Design and evolution of new catalytic activity with an existing protein scaffold. Science 311, 535-538 (2006).

[22] Stoddard BL: Homing endonuclease structure and function. Quart. Rev. Biophys. 38, 49-95 (2006).

[23] Thyme SB, Jarjour J, Takeuchi R et al.: Exploitation of binding energy for catalysis and design. Nature 461, 1300-1304 (2009).

[24] Kuhlman B, Dantas G, Ireton GC, Varani G, Stoddard BL, Baker D: Design of a novel globular protein fold with atomic-level accuracy. Science 302, 1364-1368 (2003).

[25] Dantas G, Watters AL, Lunde BM et al.: Mis-translation of a computationally designed protein yields an exceptionally stable homodimer: implications for protein engineering and evolution. J. Mol. Biol. 362, 1004-1024 (2006).

[26] Roberts RJ: How restriction enzymes became the workhorses of molecular biology. PNAS. 102, 5905-5908 (2005).

[27] Roberts RJ, Vincze T, Posfai J, Macelis D: REBASE-enzymes and genes for DNA restriction and modification. Nucl. Acids Res. 35, D269-D270 (2007).

[28] Eastberg JH, McConnell Smith A, Zhao L, Ashworth J, Shen BW, Stoddard BL: Thermodynamics of DNA target site recognition by homing endonucleases. Nucl. Acids Res. 35, 7209-7221 (2007).

[29] Xie F, Dupureur CM: Kinetic analysis of product release and metal ions in a metallonuclease. Arch. Biochem. Biophys. 483, 1-9 (2009).

[30] Kovall R.A., Matthews B.W.: Type II restriction endonucleases: Structural, functional and evolutionary relationships. Curr. Opin. Chem. Biol. 3: 578-583 (1999).

[31] Pingoud A. and Jeltsch,A. Structure and function of type II restriction endonucleases. Nucleic Acids Res., 29, 3705-3727 (2001) .

[32] Pingoud A., Fuxreiter M., Pingoud V., Wende W.: Type II restriction endonucleases: structure and mechanism. Cell. Mol. Life Sci., 62, 685-707 (2005) .

[33] 44. Winkler F.K., Banner D.W., Oefner C., Tsernoglou D., Brown R.S.,Heathman S.P., Bryan R.K., Martin P.D., Petratos K., Wilson K.S.: The crystal structure of EcoRV endonuclease and of itscomplexes with cognate and non-cognate DNA fragments. EMBO J., 12, 1781-1795 (1993).

[34] Newman M., Strzelecka T., Dorner L.F., Schildkraut I., Aggarwal A.K.: Structure of Bam HI endonuclease bound to DNA: partial folding and unfolding on DNA binding. Science, 269, 656-663 (1995).

[35] Viadiu H., Aggarwal A.K.: Structure of BamHI bound to nonspecific DNA: a model for DNA sliding. Mol. Cell, 5, 889-895 (2000).

[36] Wah DA, Bitinaite J, Schildkraut I,Aggarwal AK. Structure of FokI has implications for DNA cleavage. Proc. Natl Acad. Sci. 95, 10564-10569 (1998).

[37] Wah DA, Hirsch JA, Dorner LF, Schildkraut I, Aggarwal AK.: Structure of the multimodular endonuclease FokI bound to DNA. Nature. 388, 97-100 (1997).

[38] Smith J, Bibikova M, Whitby FG et a.: Requirements for double-strand cleavage by chimeric restriction enzymes with zinc finger DNA-recognition domains. Nucleic Acids Res. 28,3361-9. (2000).

[39] Kim S.C., Podhajska A.J., Szybalski W.: Cleaving Dna at Any Predetermined Site with Adapter-Primers and Class-Iis Restriction Enzymes. Science, 240, 504-506 (1988). [40]. Kim Y.-G., Chandrasegaran S.: Chimeric restriction endonuclease. Proc. Natl. Acad. Sci. USA 91, 883-887 (1994).

[41]. Kim Y.-G., Chandrasegaran S.: Hybrid restriction enzymes: zinc finger fusions to Fok I cleavage domain Proc. Natl. Acad. Sci. USA 93, 1156-1160 (1996). 
[42]. Kim Y.-G., Kim P. S., Herbert A., Rich A.: Construction of a Z-DNA-specific restriction endonuclease. Proc. Natl Acad. Sci. USA 94, 12875-9 (1997).

[43]. Kim Y.-G., Shi Y., Berg J. M., Chandrasegaran S.: Site-specific cleavage of DNARNA hybrids by zinc finger/FokI cleavage domain fusions. Gene 203, 43-49 (1997).

[44] Qasim W, Gaspar HB, Thrasher AJ.: Progres sand prospects: gene therapy for inherited

immunodeficiencies. Gene Ther. 16,1285-1291 (2009).

[45] Wah DA, Hirsch JA, Dorner LF, SchildkrautI, Aggarwal AK.: Structure of the multimodular endonuclease FokI bound to DNA. Nature 388, 97-100 (1997).

[46] Li L, Wu LP, Chandrasegaran S.: Functional domains in Fok I restriction endonuclease. Natl. Acad. Sci. USA Vol. 89, 4275-4279 (1992).

[47] JH. Eastberg, J. Eklund: Mutability of an HNH Nuclease Imidazole General Base and Exchange of a Deprotonation Mechanism, Biochemistry, 46, 7215-7225 (2007).

[48] Bateman A., Barney E., Cerruti L. et all.: The Pfam protein families database. Nucleic Acid Res. 30: 276-280 (2002).

[49] Kuo-Chiang Hsia, Kin-Fu Chak, Po-Huang Liang, Yi-Sheng Cheng, Wen-Yen Ku, Hanna S. Yuan: DNA Binding and Degradation by the HNH Protein ColE7. Structure. 12, 205-214 (2004).

[50] Papadakos G., Wojdyla J.A., Kleanthous C.: Nuclease colicins and their immunity proteins. Quarterly Reviews of Biophysics 45, 57-103 (2012).

[51] Meng G., Surana N. K., Geme ST et al.:Structure of the outer membrane translocator domain of the Haemophilus influenzae Hiatrimeric autotransporter. EMBO Journal 25, 2297-2304. (2006).

[52] Hsieh S.Y., Ko T.P., Tseng M.Y., Ku W., Chak K.F., Hanna S.Yuan, A novel role of ImmE7 in the autoregulatory expression of the ColE7 operon and identification of possible RNase active sites in the crystal structure of dimeric ImmE7. The EMBO Journal 16, 1444-1454 (1997).

[53] Hsia K-C, Chak K-F, Liang P-H, Cheng Y-S, Ku W-Y, Yuan HS: DNA binding and degradation by the HNH protein ColE7. Structure 12,205-214 (2004).

[54] Tzu-Ping Ko, Chen-Chung Liao, Wen-Yen Ku, Kin-Fu Chak, Hanna S. Y.:The crystal structure of the DNase domain of colicin E7 in complex with its inhibitor Im7 protein. Structure, 7, 91-102 (1999).

[55] Doudeva L.G, Huang H., Hsia K.C. et al.: Crystal structural analysis and metaldependent stability and activity studies of the ColE7 endonuclease domain in complex with DNA/Zn2+ or inhibitor/Ni2+. Protein Sci. 15: 269-280 (2006).

[56] Klenthous C., Kuhlmann, U. C, Pommer A. J. et al.: Structural and mechanistic basis of immunity toward endonuclease colicins. Nature Structural Biology 6, 243-252 (1999).

[57] Pommer A.J., Kuhlmann U.C., Cooper A., Hemmings A.M., Moore G.R., James R., Kleanthous C.: Homing in on the role of transition metals in the HNH motif of colicin endonucleases. J. Biol. Chem. 274, 27153-27160 (1999).

[58] van den Bremer E.T.J., Jiskoot W., James R., Moore G.R., Kleanthous C., Heck A.J.R., Maier C.S.:Probing metal ion binding and confor- mational properties of the colicin E9 endonuclease by electrospray ioniza- tion time-of-flight mass spectrometry. Protein Sci. 11, 1738-1752 (2002).

[59] van den Bremer E. T., Keeble A. H., Jiskoot W. et al.: Distinct conformational stability and functional activity of four highly homologous en- donuclease colicins. Protein Science 13, 1391-1401 (2004). 
[60] Ko T. P., Liao C. C., Ku W. Y., Chak K. F. et al.: The crystal structure of the DNase domain of colicin E7 in complex with its inhibitor Im7 protein. Structure 7, 91102 (1999).

[61] Alatossava T., Jutte H., Kuhn A., and Kellenberger E.: Manipula- tion of intracellular magnesium content in polymyxin B nonapeptide- sensitized Escherichia coli by lonophore. J. Bacteriol. 162, 413- 419 (1985).

[62] Kleanthous C., Walker D.: Immunity proteins: enzyme inhibitors that avoid the active site. Trends in Biochemical Sciences 26, 624-631 (2001).

[63] Wallis R., Moore G.R., James R., Kleanthous C.: Protein-protein interactions in colicin E9 DNase-immunity protein complexes. 1. Diffusion-controlled association and femtomolar binding for the cognate complex. Biochemistry 34, 13743-13750 (1995).

[64] Friedhoff P., Franke I., Meiss G., Wende W., Krause K.L., Pin- goud A.: A similar active site for non-specific and specific endonucleases. Nat. Struct. Biol. 6: 112-113 (1999).

[65] Saravanan M, Vasu K, Ghosh S, Nagaraja V.: Dual role for Zn2+ in maintaining structural integrity and inducing DNA sequence specificity in a promiscuous endonuclease. J. Biol. Chem. 282, 32320-32326 (2007).

[66] Raaijmakers H., Vix O., Toro I., Golz S., Kemper B., Suck D.:. X-ray structure of T4 endonuclease VII: A DNA junction resolvase with a novel fold and unusual domainswapped dimer architecture. EMBO J. 18, 1447-1458 (1999).

[67] Lunin V.Y., Levdikov V.M., Shlyapnikov S.V., Blagova E.V., Lunin V.V., Wilson K.S., Mikhailov A.M. Three-dimensional structure of Serratia marcescens nuclease at $1.7 \AA$ resolution and mechanism of its action. FEBS Lett. 412, 217-222 (1997).

[68] Galburt E.A., Stoddard B.L.: Catalytic mechanisms of restriction and homing endonucleases. Biochemistry 41, 13851-13860 (2002).

[69] Miller M.D., Cai J., Krause K.L. The active site of Serratia endonuclease contains a conserved magnesium-water cluster. J. Mol. Biol. 288: 975-987 (1999).

[70] Soong BW., Hsieh SY., Chak KF.: Mapping of transcriptional start sites of the cea and cei genes of the ColE7 operon. Mol. Gen. Genet. 243, 477-481(1994).

[71] Chak KF., Kuo WS., Lu FM., James R.: Cloning and characterization of the ColE7 plasmid. J. Gen. Microbiol. 137, 91-100 (1991).

[72 Mate and Kleanthous 2004] Mate M.J., Kleanthous C.: Structure-based analysis of the metal-dependence mechanism of H-N-H endonucleases. J. Biol. Chem. 279, 3476334769 (2004).

[73] $\mathrm{Ku} \mathrm{WY}$, Liu YW, Hsu YC et al.: The zinc ion in the HNH motif of the endonuclease domain of colicin E7 is not required for DNA binding but is essential for DNA hydrolysis. Nucleic Acids Res. 30, 1670-1678 (2002).

[74] Pommer A.J., Cal S., Keeble A.H., Walker D. et al.: Mechanisms and cleavage specificity of the H-N-H endonuclease colicin E9. J. Mol. Biol. 314, 735-749 (2001).

[75] Cheng YS, Hsia KC, Doudeva LG, Chak KF, Yuan HS. The crystal structure of the nuclease domain of colicin E7 suggests a mechanism for binding to double-stranded DNA by the H-N-H endonucleases. J Mol Biol 324:227- 236 (2002)

[76] Sui MJ, Tsai LC, Hsia KC et al.: Metal ions and phosphate binding in the H-N-H motif: crystal structures of the nuclease domain of ColE7/Im7 in complex with a phosphate ion and different divalent metal ions. Protein Sci 11,2947-2957 (2002)

[77] Wang YT, Yang WJ, Li CL et al.: Structural basis for sequence-dependent DNA cleavage by nonspecific endonucleases. Nucleic Acids Res 35, 1584-594 (2007)

[78] Huang H, Yuan HS The conserved asparagine in the HNH motif serves an important structural role in metal finger endonucleases. J Mol Biol 368, 812-821(2007). 
[79] Anthony LC, Suzuki H, Filutowicz M.: Tightly regulated vectors for the cloning and expression of toxic genes. J Microbiol Methods 58, 243-250 (2004).

[80] Levin KB, Dym O, Albeck S et al.: Following evolutionary paths to protein-protein interactions with high affinity and selectivity. Nat Struct Mol Biol 16,1049-1055 (2009).

[81] Liao C.-C., Hsia K.-C., Liu Y.-W., Liang P. H. et. al.: Processing of DNase domain during translocation of colicin E7 across the membrane of Escherichia coli. Biochem. Biophys. Res. Commun. 284, 556-562 (2001).

[82] Z Shi, K-F Chak, H. S. Yuan.: Identification of an Essential Cleavage Site in ColE7 Required for Import and Killing of Cells. J. Biol. Chem. 280, 26, 24663-24668 (2005).

[83] Sui M.-J., Tsai L.-C., Hsia K.-C., Doudeva L.-G. et al.: Metal ions and phosphate binding in the H-N-H motif: crystal structures of the nuclease domain of ColE7/Im7 in complex with a phosphate ion and different divalent metal ions. Protein Sci. 11, 29472957 (2002).

368, 812-821 (2007).

[84] Ku W-Y, Liu Y-W, Hsu Y-C et al.: The zinc ion in the HNH motif of the endonuclease domain of colicin E7 is not required for DNA binding but is essential for DNA hydrolysis. Nucleic Acid Res. 30, 1670-1678 (2002).

[85] Hsia K.C., Li C.L., Yuan H.S. et al.: Structural and functional insight into sugarnonspecific nucleases in host defense. Current Opinion in Structural Biology, 15, 126134 (2005).

[86] Marmur J, Doty P. Determination of the base composition of deoxyribonucleic acid from its thermal denaturation temperature. J Mol Biol. 5,109-18 (1962)

[87] Reginald H. Garret, Charles M Grisham: Biochemistry Chapter 5 Proteins: Their Biological Functions and Primary Structure, ISBN: 0030223180

[88] Lubert Stryer, Jeremy M. Berg, John L. Tymoczko: Biochemistry Chapter 4, Exploring Proteins, ISBN-10: 0-7167-3051-0

[89] KF. Chak, MK Safo, WY Ku, et al.: The crystal structure of the immunity protein of colicin E7 suggests a possible colicin-interacting surface. Proc. Natl. Acad. Sci. USA, 93, 6437-6442 (1996).

[90] D.W. Gohara, Ch.S. Ha, S.K.B. Ghosh, J.J. et al.: Production of "authentic" poliovirus RNA-dependent RNA polymerase $(3 \mathrm{D}(\mathrm{pol}))$ by ubiquitin-protease-mediated cleavage in Escherichia coli. Prot. Expr. Pur., 17, 128-138 (1999).

[91] C. Kállay, K. Ösz, A. Dávid, Z. Valastyán, G. Malandrinos, N. Hadjiliadis, I. Sóvágó, Zinc(II) binding ability of tri-, tetra- and penta-peptides containing two or three histidyl residues. Dalton Trans. 4040-4047 (2007).

[92] Sreerama N and R.W. Woody. Computation and Analysis of protein circular dichroism spectra Methods Enzymol, 383, 318. (2004)

[92] A. Czene, E. Németh, I.G. Zóka, N.I. Jakab-Simon, T. Körtvélyesi, K. Nagata, H.E.M. Christensen, B. Gyurcsik: The role of the N-terminal loop in the function of the colicin E7 nuclease domain. J. Inorg. Biol. Chem. 18, 309-321 (2013).

[93] E.T.J. Van Den Bremer, W. Jiskoot, R. James, G.R. Moore, C. Kleanthous, A.J.R. Heck, C.S. Maier: Probing metal ion binding and conformational properties of the colicin E9 endonuclease by electrospray ionization time-of-flight mass spectrometry. Protein Sci. 11, 738-1752 (2002).

[94] Schaller K., Nomura M.: Colicin E2 is a DNA endonuclease. Proc. Natl Acad. Sci. USA, 68, 3989-3993 (1976). 
[95] Garinot-Schneider C, Pommer AJ, Moore GR, Kleanthous C, James R.: Identification of putative active-site residues in the DNase domain of colicin E9 by random mutagenesis. J Mol Biol. 2, 731-42 (1996).

[96] Gasteiger E., Hoogland C., Gattiker A., Duvaud S., Wilkins M.R., Appel R.D., Bairoch A.; Protein Identification and Analysis Tools on the ExPASy Server;

(In) John M. Walker (ed): The Proteomics Protocols Handbook, Humana Press (2005). 


\section{Függelék}
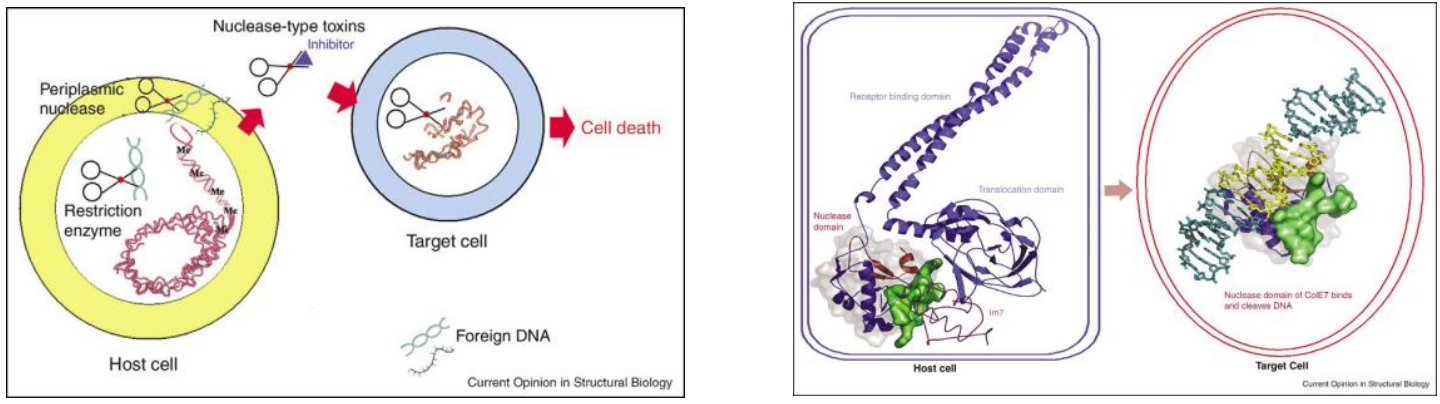

F.1. ábra: A nukleáz típusú bakteriális toxinok hasítási mechanizmusa, illete a colicinek különböző doménjeit szemléltető ábra [85].

F.2. táblázat: Baktériumok növesztésére szolgáltó tápoldatok elkészítéséhez szükséges anyagokat összefoglaló táblázat.

\begin{tabular}{|c|c|}
\hline Tápoldat típusa & Összetevők \\
\hline$\frac{11 \mathbf{L B}}{\text { (Luria Broth) tápoldat }}$ & $\begin{array}{c}10 \mathrm{~g} \text { TRIP, } 5 \text { g élesztő kivonat, } \\
10 \mathrm{~g} \mathrm{NaCl}, 1 \mathrm{ml} 1 \mathrm{M} \mathrm{NaOH}, 11 \\
\mathrm{dH}_{2} \mathrm{O}\end{array}$ \\
\hline $\begin{array}{c}0,51 \mathbf{M 9} \\
\text { (minimál) tápoldat }\end{array}$ & $\begin{array}{c}3,76 \mathrm{~g} \mathrm{Na}_{2} \mathrm{HPO}_{4} \times 2 \mathrm{H}_{2} \mathrm{O}, 1,5 \mathrm{~g} \\
\mathrm{KH}_{2} \mathrm{PO}_{4}, 0,25 \mathrm{~g} \mathrm{NaCl}, 0,5 \mathrm{~g} \\
\mathrm{NH}_{4} \mathrm{Cl}, 1 \mathrm{~g} \text { glükóz, } 1 \mathrm{ml} 1 \mathrm{M} \\
\mathrm{MgSO}_{4}, 50 \text { ul } 1 \mathrm{M} \mathrm{CaCl}_{2},\end{array}$ \\
\hline $\begin{array}{c}11 \mathbf{T B} \\
\text { (Terrific Broth) tápoldat }\end{array}$ & $\begin{array}{c}900 \mathrm{ml} \text { desztillált vízhez, } 12 \mathrm{~g} \\
\text { (bacto) tripton, } 24 \mathrm{~g} \text { (bacto) } \\
\text { élesztő kivonat, } 5,66 \mathrm{~g} 87 \%\end{array}$ \\
\hline
\end{tabular}

F.3. táblázat: A röntgen diffrakciós adatgyüjtés során kapott krisztallográfiás adatok a $\Delta 4 \mathrm{~N}-\mathrm{ColE7}$-C* fehérje egykristályáról.

\begin{tabular}{lr} 
Wavelength / $\AA$ & 1.20 \\
Space group & $P 3_{2} 21$ \\
Unit-cell parameters & \\
$\mathrm{a}=\mathrm{b} / \AA$ & 55.3 \\
$\mathrm{c} / \AA$ & 73.1 \\
$\alpha, \beta / \circ$ & 90.0 \\
$\gamma /{ }^{\circ}$ & 120.0 \\
Total reflections & 110182 \\
Unique reflections & 19723 \\
Resolution range / $\AA$ & $29(2.9-1.9)$ \\
Redundancy & $5.6(5.5)$ \\
Completeness / \% & $99.3(98.0)$ \\
$R_{\text {merge }} \dagger / \%$ & $3.7(14.3)$ \\
\hline
\end{tabular}




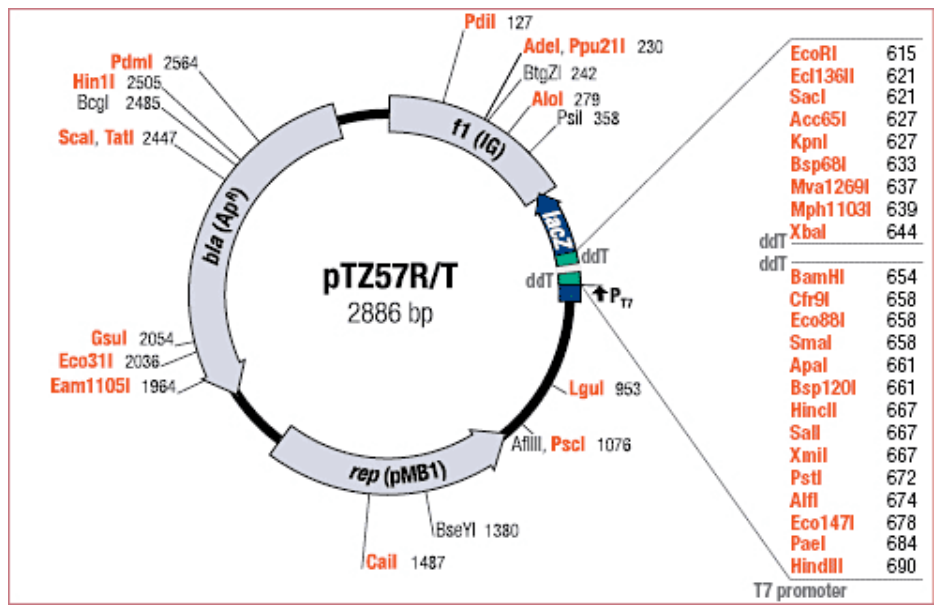

F.4. ábra: A pTZ57R klónozó vektor restrikciós térképét tartalmazó ábra.

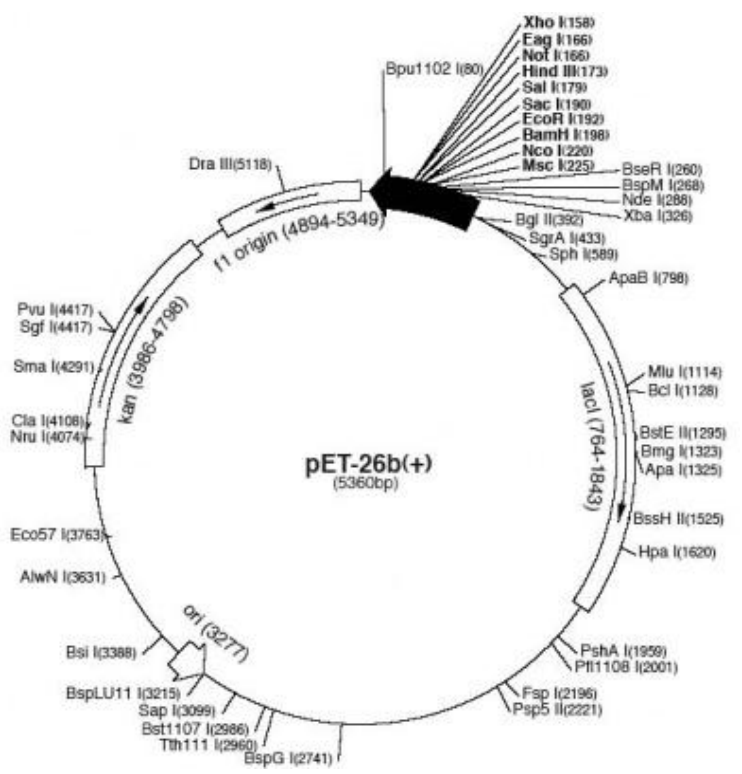

F.5. ábra: A pET26b vektor sematikus ábrája a restrikciós hasítási helyek feltüntetésével.

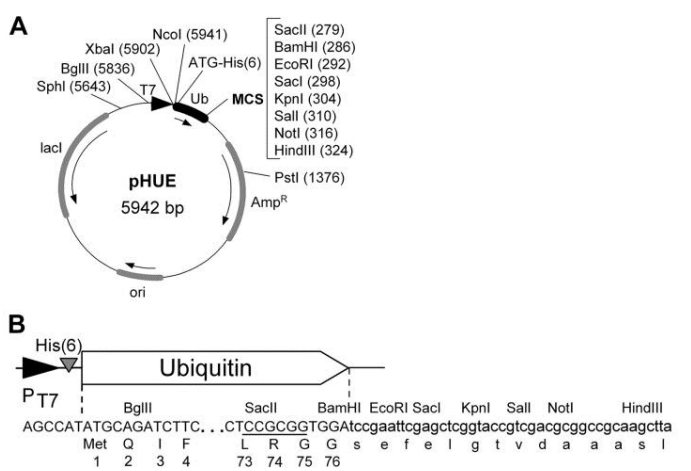

F.6. ábra: Ubikvitin-HNH fúziós rész sematikus ábrája a pHUE klónozó vektorból kiemelve 
F.7.ábra:. NColE7 fehérje DNS szekvenciája 5' $\rightarrow 3$ ' irányban ábrázolva.

AAACGGAATAAGCCAGGGAAGGCAACAGGTAAAGGA AAACCTGTCAATAATAAGTGGTTAAATAATGCAGGTAAAGACTTAGGTTCTCCTGTTCCA GATCGTATAGCTAATAAACTACGTGATAAGGAGTTTAAAAGTTTCGATGATTTTCGTAAG AAATTCTGGGAAGAAGTGTCAAAAGATCCTGAGTTAAGTAAACAATTTAGTAGGAACAAT AATGATCGAATGAAGGTTGGAAAAGCGCCCAAGACTAGAACCCAGGATGTTTCAGGGAAG AGAACTTCATTCGAGCTTCATCATGAGAAGCCGATCAGCCAAAATGGTGGTGTCTATGAT ATGGATAACATCAGCGTGGTAACACCTAAAAGGCATATTGATATTCACCGAGGTAAATAA

F.8. táblázat: A fehérjekristályosításhoz használt JSCG+ gyári screen összetétele, pirossal jelölve azt a körülményt, ahol a $\Delta 4 \mathrm{~N}-\mathrm{NColE7}$ fehérjét sikerült kikristályosítani

\begin{tabular}{|c|c|c|c|}
\hline $\begin{array}{l}\text { JCSG + } \\
\text { AN4-NColE7 }\end{array}$ & $\begin{array}{l}\text { MiCo } 4 \\
18 \mathrm{mg} \mathrm{mI} \\
20 \mathrm{~m} \mathrm{M} \mathrm{HEPES}, 0.33 \mathrm{M} \mathrm{NaCl} \\
100 \mathrm{ul} \\
0.3 \mathrm{ul}\end{array}$ & $\begin{array}{l}\text { room temp } \\
\text { DCTN\#987 }\end{array}$ & \\
\hline $\begin{array}{l}\text { Well } \\
\text { (96-well plates) }\end{array}$ & Salt & Buffer & Precipitant \\
\hline A1 & $0,2 \mathrm{M}$ Lithium sulfate & $0,1 \mathrm{M}$ Sodium acetate $\mathrm{pH} 4,5$ & $50 \% w / v$ PEG 400 \\
\hline A2 & & $0,1 \mathrm{M}$ tri-Sodium citrate $\mathrm{pH} 5,5$ & $20 \%$ W/v PEG 3000 \\
\hline A3 & $0,2 \mathrm{M}$ di-Ammonium citrate $\mathrm{pH} 5.0$ & & $20 \%$ w/v PEG 3350 \\
\hline $\begin{array}{l}\text { A4 } \\
\text { A5 }\end{array}$ & $\begin{array}{l}0,02 \mathrm{M} \text { Calcium chloride } \\
0,2 \mathrm{M} \text { Magnesium formate } \mathrm{pH} 5.9\end{array}$ & $0,1 \mathrm{M}$ Sodium acetate $\mathrm{pH} 4,6$ & $\begin{array}{l}30 \% \mathrm{~V} / \mathrm{M} \text { MPD } \\
20 \% \mathrm{~W} / \mathrm{MEG} 3350\end{array}$ \\
\hline A6 & $0,2 \mathrm{M}$ Lithium sulfate & $0,1 \mathrm{M}$ Phosphate-citrate $\mathrm{pH} 4,2$ & $20 \%$ W/v PEG 1000 \\
\hline A7 & & $0,1 \mathrm{M}$ CHES $\mathrm{pH} 9,5$ & $20 \%$ W/v PEG 8000 \\
\hline $\begin{array}{l}\text { A8 } \\
\text { A9 }\end{array}$ & $0,2 \mathrm{M}$ Ammonium formate $\mathrm{pH} 6.6$ & & $20 \%$ W/vPEG 3350 \\
\hline $\begin{array}{l}\text { A9 } \\
\text { A10 }\end{array}$ & $\begin{array}{l}0,2 \mathrm{M} \text { Ammonium chloride } \mathrm{pH} 6.3 \\
0,2 \mathrm{M} \text { Potassium formate } \mathrm{pH} 7.3\end{array}$ & & $\begin{array}{l}20 \% \text { w/vPEG } 3350 \\
20 \% \text { w/vPEG } 3350\end{array}$ \\
\hline A11 & $0,2 \mathrm{M}$ Amm monium phosphate & $0,1 \mathrm{M}$ TRIS pH 8,5 & $50 \% \mathrm{v} / \mathrm{vMPD}$ \\
\hline A12 & 0,2 M Potassium nitrate $\mathrm{pH} 6.9$ & & $20 \%$ w/v PEG 3350 \\
\hline $\begin{array}{l}\text { B1 } \\
\text { B2 }\end{array}$ & $\begin{array}{l}0,8 \mathrm{M} \text { Ammonium sulfate } \\
0,2 \mathrm{M} \text { Sodium thiocyanate } \mathrm{pH} 6.9\end{array}$ & $0,1 \mathrm{M}$ tri-Sodium citrate $\mathrm{pH} 4$ & $20 \%$ w/v PEG 3350 \\
\hline B3 & $0,2 \mathrm{M}$ Sodium thiocyanate $\mathrm{pH} 6.9$ & $0,1 \mathrm{M}$ BICINE pH 9 & $20 \%$ W/V PEG 6000 \\
\hline B4 & & & $10 \% \mathrm{w} / \mathrm{v}$ PEG $8000,8 \% \mathrm{v} / \mathrm{v}$ Ethylene glycol \\
\hline B5 & & 0,1 M Sodium cacodylate $\mathrm{pH} 6,5$ & $40 \%$ \%/v MPD, $5 \%$ w/v PEG 8000 \\
\hline $\begin{array}{l}\text { B6 } \\
\text { B7 }\end{array}$ & & $\begin{array}{l}\text { 0,1 M Phosphate-citrate } \mathrm{pH} 4,2 \\
\mathbf{0}, 1 \text { M Sodium acetate } \mathbf{p H} 4,6\end{array}$ & $\begin{array}{l}40 \% \text { \%v/v Ethanol, } 5 \% \text { \% w/v PEG } 1000 \\
8 \text { \% \%w/v PEG 4000 }\end{array}$ \\
\hline B8 & $0,2 \mathrm{M}$ Magnesium chloride & $0,1 \mathrm{M}$ TRIS $\mathrm{pH} 7$ & $10 \%$ W/V PEG 8000 \\
\hline B9 & & 0,1 M tri-Sodium citrate $\mathbf{p H} 5$ & $20 \%$ W/v PEG 6000 \\
\hline B10 & $0,2 \mathrm{M}$ Magnesium chloride & $0,1 \mathrm{M}$ Sodium cacodylate $\mathrm{pH} 6,5$ & $50 \%$ V/V PEG 200 \\
\hline B11 & 1,6 M tri-Sodium citrate & & $20 \%$ w/v PEG 3350 \\
\hline B12 & $0,2 \mathrm{M}$ tri-Potassium citrate $\mathrm{pH} 8.3$ & & $20 \%$ w/v PEG 3350 \\
\hline $\mathrm{C}_{\mathrm{C}}$ & $0,2 \mathrm{M}$ Sodium chloride & $0,1 \mathrm{M}$ Phosphate-citrate $\mathrm{pH} \mathrm{4,2}$ & $20 \%$ w/v PEG 8000 \\
\hline $\begin{array}{c}\mathrm{C} 2 \\
\mathrm{C} 3\end{array}$ & $\begin{array}{l}1 \mathrm{M} \text { L Lithium chloride } \\
0,2 \mathrm{M} \text { Ammonium nitrate } \mathrm{pH} 6.3\end{array}$ & $0,1 \mathrm{M}$ tri-Sodium citrate $\mathrm{pH} 4$ & $\begin{array}{l}20 \% \text { \% w/v PEG } 6000 \\
20 \% \text { P PEG } 3350\end{array}$ \\
\hline $\mathrm{C} 4$ & & $0,1 \mathrm{M}$ HEPES $\mathrm{pH} 7$ & $10 \% \mathrm{w} / \mathrm{V}$ PEG 6000 \\
\hline C5 & & $0,1 \mathrm{M}$ HEPES $\mathrm{pH} 7,5$ & $0,8 \mathrm{M}$ Sodium phosphate, $0,8 \mathrm{M}$ Potassium pho \\
\hline C6 & & 0,1 M Phosphate-citrate $\mathrm{pH} 4,2$ & $40 \% \mathrm{v} / v$ PEG 300 \\
\hline $\begin{array}{ll}\mathrm{C} 7 \\
\mathrm{C} 8\end{array}$ & $0,2 \mathrm{M}$ Znc acetate & $\begin{array}{l}0,1 \mathrm{M} \text { Sodium acetate } \mathrm{pH} 4,5 \\
0,1 \mathrm{M} \text { TRIS } \mathrm{pH} 8,5\end{array}$ & $\begin{array}{l}10 \% \text { \% w P PEG } 3000 \\
20 \% \text { V Ethanol }\end{array}$ \\
\hline $\mathrm{c9}$ & & $0,1 \mathrm{M} \mathrm{Na} / \mathrm{K}$ phosphate $\mathrm{pH} 6,2$ & $25 \% \mathrm{v} / \mathrm{v} 1,2$ propandiol, $10 \% \mathrm{v} / \mathrm{v}$ Glycerol \\
\hline $\begin{array}{l}\text { C10 } \\
\text { C11 }\end{array}$ & 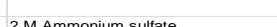 & $0,1 \mathrm{M}$ BICINE pH 9 & $10 \%$ w/v PEG $20000,2 \%$ V/v Dioxane \\
\hline C12 & $2 \mathrm{M}$ Ammonium sulfate & $0,1 \mathrm{M}$ Sodium acetate $\mathrm{PH} 4,6$ & $10 \%$ w/v PEG $1000,10 \%$ w/v PEG 8000 \\
\hline D1 & & & $24 \%$ w/v PEG $1500,20 \%$ w/v glycerol \\
\hline $\mathrm{D} 2$ & 0,2 M Magnesium chloride & 0,1 M HEPES pH 7,5 & $30 \%$ \%/v PEG 400 \\
\hline $\begin{array}{l}\mathrm{D} 3 \\
\mathrm{D} 4\end{array}$ & $\begin{array}{l}0,2 \mathrm{M} \text { Sodium chloride } \\
\mathbf{0}, 2 \mathrm{M} \text { Lithium sulfate }\end{array}$ & $\begin{array}{l}0,1 \text { M Na/K phosphate } \mathrm{pH} 6,2 \\
\mathbf{0}, \mathbf{1} \text { M Sodium acetate } \mathrm{pH} \mathbf{4 , 5}\end{array}$ & $\begin{array}{l}50 \% \mathrm{v} / \mathrm{V} \text { PEG } 200 \\
30 \% \text { P }\end{array}$ \\
\hline $\begin{array}{l}\text { D4 } \\
\text { D5 }\end{array}$ & $\begin{array}{l}0,2 \mathrm{M} \text { Lithium sulfate } \\
0,2 \mathrm{M} \text { Magnesium chloride }\end{array}$ & $\begin{array}{l}\text { 0,1 M Sodium acetate pH 4,5 } \\
0,1 \mathrm{M} \mathrm{HEPES} \mathrm{pH} 7,5\end{array}$ & $\begin{array}{l}30 \% \text { w/v PEEG } 8000 \\
70 \% \mathrm{v} / \mathrm{v} \mathrm{MPD}\end{array}$ \\
\hline D6 & & $0,1 \mathrm{M}$ TRIS pH 8,5 & $20 \%$ W/v PEG 8000 \\
\hline D7 & $0,2 \mathrm{M}$ Lithium sulfate & $0,1 \mathrm{M}$ TRIS $\mathrm{pH} 8,5$ & $40 \% \mathrm{v} / \mathrm{VPEG} 400$ \\
\hline D8 & & $0,1 \mathrm{M}$ TRIS $\mathrm{pH} 8$ & $40 \% \mathrm{v} / \mathrm{v}$ MPD \\
\hline D9 & $0,17 \mathrm{M}$ Ammonium sulfate & & $25,5 \% \mathrm{w} / \mathrm{v}$ PEG $4000,15 \% \mathrm{w} / \mathrm{v}$ Glycerol \\
\hline D10 & $0,2 \mathrm{M}$ Calcium acetate & $0,1 \mathrm{M}$ Sodium cacodylate $\mathrm{pH} 6,5$ & $40 \%$ v/v PEG 300 \\
\hline $\begin{array}{l}\text { D11 } \\
\text { D12 }\end{array}$ & $0,14 \mathrm{M}$ Calcium chloride & 0,07 M Sodium acetate $\mathrm{pH} 4,6$ & $14 \% \mathrm{v} / \mathrm{v}$ Isopropanol, $30 \% \mathrm{v} / \mathrm{v}$ Glycerol \\
\hline $\begin{array}{l}\text { Di2 } \\
\text { E1 }\end{array}$ & $\begin{array}{l}\text { 0,04 M Potassium phosphate } \\
1 \mathrm{M} \text { tri-Sodium citrate }\end{array}$ & $0,1 \mathrm{M}$ Sodium cacodylate $\mathrm{pH} 6,5$ & $16 \%$ W/V PEG $8000,20 \%$ V/v Gilycerol \\
\hline E2 & $0,2 \mathrm{M}$ Sodium chloride & $0,1 \mathrm{M}$ Sodium cacodylate $\mathrm{pH} 6,5$ & $2 \mathrm{M}$ Ammonium sulfate \\
\hline E3 & $0,2 \mathrm{M}$ Sodium chloride & 0,1 M HEPES $\mathrm{pH} 7,5$ & $10 \% \mathrm{v} / \mathrm{v}$ Isopropanol \\
\hline $\begin{array}{l}\text { E4 } \\
\text { E5 }\end{array}$ & $0,2 \mathrm{M}$ Lithium sulfate & $0,1 \mathrm{M}$ TRIS $\mathrm{pH} 8,5$ & 1,26 M Ammonium sulfate \\
\hline E6 & $0,2 \mathrm{M}$ Znc acetate & $\begin{array}{l}0,1 \mathrm{M} \text { CAPS } \mathrm{pH} 10,5 \\
0,1 \mathrm{M} \text { Imidazole } \mathrm{pH} 8\end{array}$ & $\begin{array}{l}40 \% \text { \%V/vMPD } \\
20 \% \text { M } 3000\end{array}$ \\
\hline E7 & $0,2 \mathrm{M} Z \mathrm{Znc}$ acetate & $0,1 \mathrm{M}$ Sodium cacodylate $\mathrm{pH} 6.5$ & $10 \% \mathrm{v} / \mathrm{V}$ Is sopropanol \\
\hline E8 & $1 \mathrm{M} \mathrm{di}$-Ammonium phosphate & $0,1 \mathrm{M}$ Sodium acetate $\mathrm{pH} 4,5$ & \\
\hline E9 & 1,6 M Magnesium sulfate & 0,1 M MES PH 6,5 & \\
\hline E10 & & $0,1 \mathrm{M}$ BICINE pH 9 & $10 \%$ w/v PEG 6000 \\
\hline E11 & $0,16 \mathrm{M}$ Calcium acetate & $0,08 \mathrm{M}$ Sodium cacodylate $\mathrm{pH} 6,5$ & $14,4 \%$ W/v PEG $8000,20 \%$ v/v Glycerol \\
\hline $\begin{array}{l}\mathrm{E} 12 \\
\mathrm{~F} 1\end{array}$ & $0,05 \mathrm{M}$ Cesium chloride & $\begin{array}{l}0,1 \mathrm{M} \mathrm{Imidazole} \mathrm{pH} 8 \\
0,1 \mathrm{M} \text { MES } \mathrm{PH} 6,5\end{array}$ & $\begin{array}{l}10 \% \text { \% } / / \text { PEG } 8000 \\
30 \% \text { p J Jeffamine M-600 }\end{array}$ \\
\hline F2 & 3,15 M Ammonium sulfate & $0,1 \mathrm{M}$ tri-Sodium citrate $\mathrm{pH} 5$ & \\
\hline F3 & & $0,1 \mathrm{M}$ TRIS pH 8 & $20 \% \mathrm{v} / \mathrm{v}$ MPD \\
\hline $\mathrm{F} 4$ & 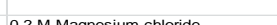 & $0,1 \mathrm{M}$ HEPES $\mathrm{pH} 6,5$ & $20 \%$ w/v Jeffamine M-600 \\
\hline $\begin{array}{l}\text { F5 } \\
\text { F6 }\end{array}$ & $0,2 \mathrm{M}$ Magnesium chloride & $\begin{array}{l}0,1 \mathrm{M} \text { TRIS } \mathrm{pH} 8,5 \\
0,1 \mathrm{M} \mathrm{BICINE} \mathrm{pH} 9\end{array}$ & $50 \%$ v/v Ethylene glycol \\
\hline F7 & $0,8 \mathrm{M}$ Succinic acid $\mathrm{pH} 7.0$ & & \\
\hline F8 & 2,1 M DL-Malic acid pH 7.0 & & \\
\hline $\begin{array}{l}\text { F9 } \\
\text { F10 }\end{array}$ & $\begin{array}{l}\text { 2,4 M Sodium malonate } \mathrm{pH} 7.0 \\
1,1 \mathrm{M} \text { Sodium malonate } \mathrm{pH} 7.0\end{array}$ & $0,1 \mathrm{M}$ HEPES $\mathrm{pH} 7$ & $0,5 \% \mathrm{v} / \mathrm{V}$ Jeffamine ED-2001 $\mathrm{pH} 7.0$ \\
\hline F11 & 1 M Succinic acid pH 7.0 & $0,1 \mathrm{M}$ HEPES $\mathrm{pH} 7$ & $1 \%$ W/V PEG MME 2000 \\
\hline F12 & & $0,1 \mathrm{M}$ HEPES $\mathrm{pH} 7$ & $30 \%$ v/v Jeffamine $\mathrm{M}-600 \mathrm{pH} 7.0$ \\
\hline G1 & & $0,1 \mathrm{M} \mathrm{HEPES} \mathrm{pH} 7$ & 30 \% v/v Jeffamine ED-2001 pH 7.0 \\
\hline $\mathrm{G} 2$ & 0,02 M Magnesium chloride & $\begin{array}{l}0,1 \mathrm{M} \text { HEPES pH } 7,5 \\
01 \text { MEIS }\end{array}$ & $22 \%$ w/v Polyacrylic acid 5100 sodium salt \\
\hline $\mathrm{G}_{4}$ & $\begin{array}{l}0,1 \mathrm{M} \text { Cobalt chloride } \\
0,2 \mathrm{M} \text { Trimethylamine } \mathrm{N} \text {-oxide }\end{array}$ & $\begin{array}{l}0,1 \mathrm{M} \text { TRS } \mathrm{pH} 8,5 \\
0,1 \mathrm{M} \text { TRIS } \mathrm{pH} 8,5\end{array}$ & 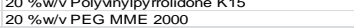 \\
\hline G5 & $0,005 \mathrm{M}$ Cobalt chloride $0,005 \mathrm{M}$ & 0,1 M HEPES pH 7,5 & \\
\hline G6 & $0,2 \mathrm{M}$ Sodium malonate $\mathrm{pH} 7.0$ & & $20 \%$ W/v PEG 3350 \\
\hline G7 & $0,1 \mathrm{M}$ Succinic acid $\mathrm{pH} 7.0$ & & $15 \% \mathrm{~W} / \mathrm{V}$ PEG 3350 \\
\hline G8 & & & $20 \%$ W/v PEG 3350 \\
\hline G9 & $0,1 \mathrm{M}$ Potassium thiocyanate & & $\begin{array}{l}30 \% \mathrm{~W} / \mathrm{VPEG} \text { MME } 2000 \\
30 \% \mathrm{~W} / \mathrm{PEG} \text { MME } 2000\end{array}$ \\
\hline G11 & $\begin{array}{l}\text {, 15 M Potassium bromide } \\
\text { 2 M Ammonium sulfate }\end{array}$ & $0,1 \mathrm{M}$ bis-TRIS $\mathrm{pH} 5,5$ & \\
\hline G12 & 3 M Sodium chloride & $0,1 \mathrm{M}$ bis-TRIS pH 5,5 & \\
\hline $\mathrm{H} 1$ & $0,3 \mathrm{M}$ Magnesium formate & $0,1 \mathrm{M}$ bis-TRIS $\mathrm{pH} 5,5$ & \\
\hline$H^{H 2}$ & $1 \mathrm{M}$ Ammonium sulfate & $0,1 \mathrm{M}$ bis-TRIS pH 5,5 & $\begin{array}{l}\text { 1\%W/VPEG } 3350 \\
25 \% \text { W } / \text { PEG } 3350\end{array}$ \\
\hline H4 & $0,2 \mathrm{M}$ Calcium chloride & $\begin{array}{l}0,1 \mathrm{M} \mathrm{bis} \text {-TRS pH 5,5 } \\
\text { 0,1 M bis-TRIS pH 5,5 }\end{array}$ & $\begin{array}{l}25 \% \mathrm{w} / \mathrm{v} P E G \mathrm{~B} 350 \\
\mathbf{4 5} \% \mathrm{v} / \mathrm{MPD}\end{array}$ \\
\hline $\mathrm{H} 5$ & $0,2 \mathrm{MAmmonium}$ acetate & $0,1 \mathrm{M}$ bis-TRIS pH 5,5 & $45 \% \mathrm{~V} / \mathrm{V}$ MPD \\
\hline $\mathrm{H6}$ & $0,1 \mathrm{M}$ Ammonium acetate & $0,1 \mathrm{M}$ bis-TRIS $\mathrm{pH} \mathrm{5,5}$ & $17 \%$ W/VPEG 10,000 \\
\hline $\begin{array}{l}\mathrm{H} 7 \\
\mathrm{H} 8\end{array}$ & 0,2 M Ammonium sulfate & $0,1 \mathrm{M}$ bis-TRIS pH 5,5 & $\begin{array}{l}25 \% \text { \%/VPEG } 3350 \\
25 \% \text { P }\end{array}$ \\
\hline $\begin{array}{l}\mathrm{H} 8 \\
\mathrm{Ha}\end{array}$ & $\begin{array}{l}0,2 \mathrm{M} \text { Sodium chloride } \\
0,2 \mathrm{M} \text { Lithium sulfate }\end{array}$ & $\begin{array}{l}0,1 \mathrm{M} \text { bis-TRII } \mathrm{PH} 5,5 \\
0,1 \mathrm{M} \text { bis-TRIS } \mathrm{pH} 5,5\end{array}$ & $\begin{array}{l}25 \% \text { \% } / / \text { PEG } 3350 \\
25 \% \text { P PEG } 3350\end{array}$ \\
\hline $\mathrm{H} 10$ & $0,2 \mathrm{M}$ Ammonium acetate & $0,1 \mathrm{M}$ bis-TRIS pH 5,5 & $25 \%$ W/V PEG 3350 \\
\hline $\begin{array}{l}\mathrm{H} 11 \\
\mathrm{H} 12\end{array}$ & $\begin{array}{l}0,2 \mathrm{M} \text { Magnesium chloride } \\
0,2 \mathrm{M} \text { Ammonium acetate }\end{array}$ & $\begin{array}{l}0,1 \mathrm{M} \text { bis-TRIS pH 5,5 } \\
0,1 \mathrm{M} \text { HEPES pH 7,5 }\end{array}$ & $\begin{array}{l}25 \% \text { w/v PEG } 3350 \\
45 \% \mathrm{v} / v \text { MPD }\end{array}$ \\
\hline
\end{tabular}


T7 promoter primer \#69348-3

Bg/II T7 promoter

lac operator

Xbal

rbs

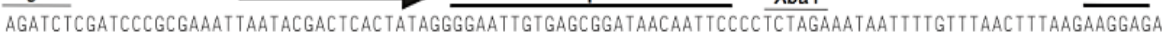

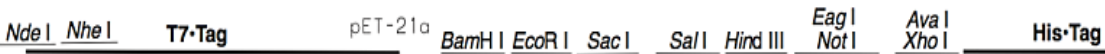

TATACATATGGCTAGCATGACTGGTGGACAGCAAATGGGTCGCGGATCCGAATTCGAGCTCCGTCGACAAGCTTGCGGCCGCACTCGAGCACCACCACCACCACCACTGA MetAl aSerMetThrGlyGIyG I nG I MetG IyArgG IySerG I uPheG I uLeuArgArgG I nA I aCysG IyArgThrArgA I PProProProProProLeu

\begin{tabular}{|c|c|c|}
\hline$\stackrel{\text { PET-21d }}{\text { Ncol }}$ & $p E T-21 b$ & 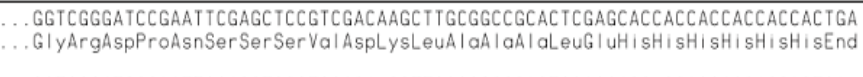 \\
\hline $\begin{array}{l}. . \text { TACCATGGCTAGC... } \\
\text { MetAlaSer... }\end{array}$ & $p E T-21 c, d$ & $\begin{array}{l}\text {..GGTCGGATCCGATTCGAGCTCCGTCGACAAGCTTGCGGCCGCACTCGAGCACCACCACCACCACCACTGA } \\
\text { GlyArgI IeArgI IeArgAlaProSerThrSerLeuArgProHisSerSerThrThrThrThrThrThrGIu }\end{array}$ \\
\hline
\end{tabular}
Bpu1102I

T7 terminator

GATCCGGCTGCTAACAAAGCCCGAAAGGAAGCTGAGTTGGCTGCTGCCACCGCTGAGCAATAACTAGCATAACCCCTTGGGGC TCTAAACGGGTCTTGAGGGGTTTTTTG

$T 7$ terminator primer \#69337.3

\section{pET-21a-d(+) cloning/expression region}

F.9. ábra: A pET21a vektor kiemelt klónozási régiója 


\section{A disszertáció alapját képező közlemények}

1. B. Gyurcsik, A. Czene: Towards artificial metallonucleases for gene therapy: recent advances and new perspectives.

Future Med. Chem., 3, 1935-1966 (2011)

$\mathrm{IF}=2,522$

2. A. Czene, E. Németh, I.G. Zóka, N.I. Jakab-Simon, T. Körtvélyesi, K. Nagata, H.E.M. Christensen and B. Gyurcsik: On the role of the N-terminal loop in the function of colicin E7 nuclease domain.

J. Biol. Inorg. Chem., 18, 309-321 (2013)

$\mathrm{IF}=3,289$

3. B. Gyurcsik, A. Czene, H. Barát-Jankovics, N.I. Simon-Jakab, K. Ślaska-Kiss, A. Kiss and Z. Kele: Cloning, purification and metal binding of the HNH motif from colicin E7

Protein Exp. Pur.89, 210-218 (2013)

$\mathrm{IF}=1,587$

4. A. Czene, E. Tóth, B. Gyurcsik, H. Otten, J.-C.N. Poulsen, Leila Lo Leggio, S. Larsen, H.E.M. Christensen and K. Nagata: Crystallization and preliminary crystallographic analysis of an E. coli selected mutant of the nuclease domain of Colicin E7 metallonuclease.

Acta Cryst. Sect F.69,551-554 (2013)

$\mathrm{IF}=0,510$

5. A. Czene, E. Tóth, B. Gyurcsik, H. Otten, J.-C.N. Poulsen, S. Larsen, H.E.M. Christensen and K. Nagata: The crystal structure of a mutant of the nuclease domain of Colicin E7 metallonuclease exhibits an introverted N-terminus.

Acta Cryst. Sect D. (2013) elökészületben

$\Sigma$ IF $=7,908$ 


\section{Konferencia megjelenések}

\section{Konferencia proceeding:}

1. B. Gyurcsik, A. Czene, E. Endreffy, and K. Nagata: Chimeric metallonucleases for gene therapy Insights Into Coordination, Bioinorganic, And Applied Inorganic Chemistry, Monograph Series of the International Conferences on Coordination and Bioinorganic Chemistry held periodically at Smolenice in Slovakia, Ed.: M. Melník, P. Segl'a, M. Tatarko, ISBN 978-80-227-3085-3, ISSN 1335-308X, Slovak Technical University Press, Bratislava, 2009, 9, 81-88.

\section{Konferencia előadások és poszterek:}

1. A. Czene, B. Gyurcsik, E. Endreffy, K. Nagata: Novel diagnosis of Duchenne Muscular Dystrophy

Graduate School on Metal Ions in Biological systems (MIBS) - Current Trends and Methods in Bioinorganic Chemistry, 7-10 September, Søminestationen - Holbæk, Denmark, (2009) - poster + oral presentation

2. B. Gyurcsik, N.I. Jakab, A. Czene, E. Endreffy, K. Nagata: Artificial Metallonucleases For Gene Therapy

10th International Symposium on Applied Bioinorganic Chemistry (ISABC 10). Sept. 25-28, 2009, Debrecen, Hungary (2009) - section lecture

3. B. Gyurcsik, A. Czene, E. Endreffy, K. Nagata: Chimeric metallonucleases for gene correction.

The Tokyo Tech-UNESCO Fellows Symposium for Development of Human Resources and Research Network in Science and Technology, 10-11 ${ }^{\text {th }}$ December, 2009, Tokyo, Japan (2009) - poster

4. B. Gyurcsik, A. Czene, A. Jancsó: The effect of metal ions on the SRCD spectral pattern of peptides and proteins.

ISA/ASTRID User Meeting, Aarhus, Denmark, $28^{\text {th }}-29^{\text {th }}$ January (2010), - poster.

5. A. Czene, I.N. Jakab-Simon, B. Gyurcsik, K. Nagata, H.E.M. Christensen: New type of chimeric metallonucleases for gene therapy, DTU Bioinorganic Chemistry Meeting, Lyngby Denmark, 28th-29th March (2010), - poster

6. B. Gyurcsik, G. Nagy, A. Czene, T. Körtvélyesi: Design of a new type zinc-finger chimeric nuclease, EUROBIC10 - 10th European Biological Inorganic Chemistry Conference, Thessaloniki, Greece, June 22 - June 26, 2010. - poster

7. B. Gyurcsik, A. Czene, N.I. Simon, E. Németh, I.G. Zóka, G. Nagy, T. Körtvélyesi, H.E.M. Christensen, K. Nagata: Study on the HNH motif as a possible component of a controlled zinc-finger nuclease. International Conference on Gene Targeting, Vienna, Austria, 9-12th February (2011), - lecture

8. B. Gyurcsik, A. Czene, N.I. Simon, E. Németh, I.G. Zóka, G. Nagy, T. Körtvélyesi, H.E.M. Christensen, K. Nagata: Study on the HNH motif as a possible component of a controlled zinc-finger nuclease. New Trends in Coordination, Bioinorganic and Applied Inorganic Chemistry; XXIII. International Conference on Coordination and Bioinorganic Chemistry, Smolenice, Slovak Republic, 5 10th June (2011), - lecture

9. B. Gyurcsik, A. Czene, I.N. Simon, E. Németh, I.Gy. Zóka, T. Körtvélyesi, H.E.M. Christensen, K. Nagata: Allosteric control in the nuclease domain of colicin E7. QBIC-3 $3^{\text {rd }}$ Quantum Bioinorganic Chemistry Conference, Cesky Krumlov, Czech Republic, 25-28 June, (2011) - poster 
10. A. Czene, B. Gyurcsik, E. Endreffy, K. Nagata: Novel diagnosis of Duchenne muscular dystrophy. 4th European Conference on Chemistry for Life Sciences (4ECCLS), Budapest, Hungary, August 31September 3 (2011) - poster

11. B. Gyurcsik, A. Czene, N.I. Simon, E. Németh, I.G. Zóka, T. Körtvélyesi, H.E.M. Christensen, K. Nagata: Study on the HNH motif as a possible component of a controlled zinc-finger nuclease. 4th European Conference on Chemistry for Life Sciences (4ECCLS), Budapest, Hungary, August 31September 3 (2011) - lecture

12. B. Gyurcsik, A. Czene, I.N. Simon, E. Németh, I.Gy. Zóka, T. Körtvélyesi, H.E.M. Christensen, K. Nagata: Allosteric control in the nuclease domain of colicin E7, International Workshop on Metal Containing Drugs, Szeged, Hungary, 30-31 August (2011) - lecture

13. B. Gyurcsik, A. Czene, N.I. Simon, E. Németh, I.G. Zóka, T. Körtvélyesi, H.E.M. Christensen, K. Nagata: Design of a novel artificial nuclease based on the HNH.

ISABC11 - 11th International Symposium on Applied Bioinorganic Chemistry, Barcelona, Spain, 2-5 December (2011)-poster

14. A. Czene, E. Németh, I.G. Zóka, N.I. Simon, B. Gyurcsik, H.E.M. Christensen, K. Nagata: Mutant Colicin E7 proteins reveal the conditions for allosteric control of the enzymatic action.

ISABC11 - 11th International Symposium on Applied Bioinorganic Chemistry, Barcelona, Spain, 2-5 December (2011)-poster

15. B. Gyurcsik, A. Czene, E. Németh, I.G. Zóka, E. Endreffy, H.E.M. Christensen, K. Nagata: Targeting the breakpoint in duchenne muscular dystrophy.

Nobel75, 75th Anniversary of Albert Szent-Györgyi's Nobel Prize Award, Szeged, Hungary, 22-25 March (2012)-lecture

16. A. Czene, B. Gyurcsik, E. Endreffy: A simple carrier detection method in Duchenne muscular dystrophy affected families.

IIIrd HuRo conference - Genetic diagnostic method developments, Szeged, Hungary, $27^{\text {th }}$ April (2012) lecture

17. B. Gyurcsik, A. Czene, E. Németh, I.G. Zóka, E. Endreffy, H.E.M. Christensen, K. Nagata: Targeting the breakpoint in Duchenne Muscular Dystrophy

ISMEC 2012, International Symposia on Metal Complexes, Lisbon, Portugal, June $18^{\text {th }}-22^{\text {nd }}$, ISMEC Acta, Vol. 2, p.111 (2012)-poster

18. B. Gyurcsik, A. Czene, E. Németh, I.G. Zóka, E. Endreffy, H.E.M. Christensen, K. Nagata: Targeting the breakpoint in Duchenne Muscular Dystrophy by an artificial metallonuclease.

EUROBIC11, 11th European Biological Inorganic Chemistry Conference, Granada, Spain September 1216 (2012) - poster

19. B. Gyurcsik, A. Czene, E. Németh, I.Gy. Zóka, E. Endreffy, H.E.M. Christensen, K. Nagata: Design of a novel artificial metallonuclease for targeting the breakpoint in Duchenne Muscular Dystrophy.

The 3rd Leading Graduate Schools International Conference, Tsukuba, Japan, November 1-2 (2012), invited lecture 
20. E. Endreffy, A. Czene, B. Gyurcsik: Carrier diagnostics with different molecular genetic methods in dystrophinopathy.

Newborn screening and molecular diagnostics of inherited disorders - HuRo conference Szeged, January 25, (2013)-Lecture

21. Czene A., Gyurcsik B.: A Duchenne féle izomdisztrófia újfajta diagnosztikája XXXI. Kémiai Előadói Napok, 2008. október 29-29, Szeged.

22. Németh E., Zóka I.Gy., Czene A., Jakab-Simon I.N., Gyurcsik B., Körtvélyesi T., Nagata K., Christensen H.E.M.: A colicin E7 fehérje nukleáz doménjének vizsgálata.

MKE, 1. Nemzeti konferencia, Sopron 2011. május 22-25 - előadás

23. Czene A., Gyurcsik B.: A Duchenne-féle izomdisztrófia újfajta diagnosztikája

MKE, 1. Nemzeti konferencia, Sopron 2011. május 22-25 - poszter

24. Zóka I. Gy., Gyurcsik B., Czene A., Németh E.: A colicin E7 nukleáz N-terminális végén rövidített mutáns fehérjéinek vizsgálata.

XXXIV. Kémiai Elöadói Napok, Szeged, 2011. November 2-4 - előadás

25. Gyurcsik B., Czene A., Németh E., Tóth E., Zóka I.Gy.: Aktiváló allosztérikus szabályozás kialakításának lehetősége egy Colicin E7 alapú mesterséges metallonukleázban.

46. Komplexkémiai Kollokvium és az MTA Koordinációs Kémiai Munkabizottság ülése, 2012. május 2123, Mátrafüred - előadás

26 Czene A., Gyurcsik B., Christensen H.E.M.: Colicin E7 metallonukleáz fehérje mutánsainak előállítása szerkezetmeghatározás céljából.

46. Komplexkémiai Kollokvium és az MTA Koordinációs Kémiai Munkabizottság ülése, 2012. május 2123, Mátrafüred - előadás

27 Tóth E., Czene A., H. Otten, J.-Ch. Navarro-Poulsen, S. Larsen, Gyurcsik B.: A $\Delta$ N4-NColE7 metallonukleáz mutáns kristályszerkezete.

46. Komplexkémiai Kollokvium és az MTA Koordinációs Kémiai Munkabizottság ülése, 2012. május 2123, Mátrafüred - előadás 


\section{Köszönetnyílvánítás}

Köszönetet mondok Dr. Kiss Tamás tanszékvezető egyetemi tanárnak, aki lehetővé tette számomra, hogy munkámat a Szervetlen és Analitikai Kémiai Tanszéken elkészítsem.

Köszönettel tartozom Dr. Gyurcsik Béla témavezetömnek, aki mindvégig sokat segített a mérések kivitelezésében és kiértékeléséhez, hasznos szakmai tanácsaival hozzásegített a kémia alaposabb megismeréséhez.

Köszönetet mondok Dr. Hans Erik M. Christensennek a fehérjék kifejezésben nyújtott segítségért.

Köszönet illeti Dr. Sine Larsent, Jens-Christian Navarro Poulsent, Dr. Harm Ottent és Tóth Esztert a diffrakciós adatok feldolgozásáért, a kristályszerkezet megfejtéséért és értelmezése során nyújtott segítségért.

Köszönet illeti továbbá a Szervetlen és Analitikai Kémiai Tanszék munkatársait.

Munkámat az OTKA-NKTH CK 80850 és TÁMOP-4.2.2/B-10/1-2010-0012 projektek, valamint a Magyar Ösztöndíj Bizottság támogatta. 